\title{
SAPHIRE 8 Software Project Plan
}

\section{March 2010}
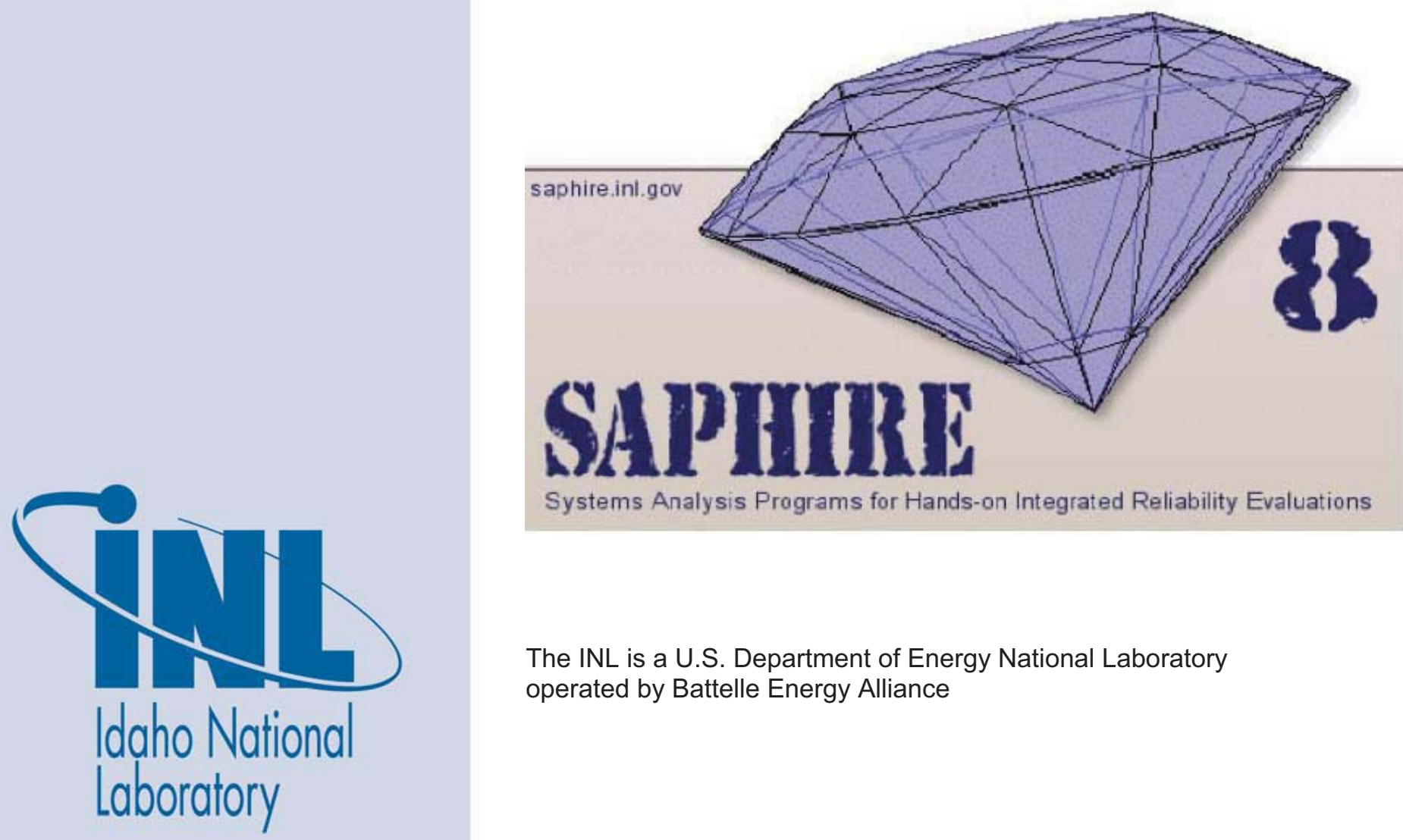

Systems Analysis Programs for Hands-on Integrated Reliability Evaluations

The INL is a U.S. Department of Energy National Laboratory operated by Battelle Energy Alliance 
INL/EXT-09-15853

Rev. 4

\section{SAPHIRE 8 Software Project Plan}

March 2010

\section{Idaho National Laboratory \\ Idaho Falls, Idaho 83415}

http://www.inl.gov

Prepared for the

U.S. Nuclear Regulatory Commission

Washington, DC 20555

Project No. N6423 


\begin{tabular}{|l|ll|}
\hline \multicolumn{2}{|l|}{ Pdaho National Laboratory 1 of 74} \\
\hline SOFTWARE PROJECT PLAN & Identifier: & INL/EXT-09-15853 \\
for SAPHIRE Version 8 N6423 & Revision: & 4 \\
& Effective Date: & $3 / 3 / 2010$ \\
\hline
\end{tabular}

\section{REVISION LOG}

\begin{tabular}{|c|c|c|c|}
\hline $\begin{array}{l}\text { Revision } \\
\text { Number } \\
\end{array}$ & $\begin{array}{l}\text { Effective } \\
\text { Date }\end{array}$ & $\begin{array}{l}\text { Affected } \\
\text { Pages }\end{array}$ & Description of Change \\
\hline 0 & $07 / 15 / 2009$ & 0 & Initial issue (Preliminary Project Execution Plan) \\
\hline 1 & & & $\begin{array}{l}\text { Updated multiple pages to reflect IV\&V comments } \\
\text { and concerns. }\end{array}$ \\
\hline 2 & & & $\begin{array}{l}\text { Updated multiple pages for editorial changes and to } \\
\text { respond to IV\&V review comments. }\end{array}$ \\
\hline 3 & & & $\begin{array}{l}\text { Modifications based upon the IV\&V review of } \\
\text { Revision } 2\end{array}$ \\
\hline 4 & & $\begin{array}{c}\text { Section } \\
3.4\end{array}$ & Modifications based upon NRC comments \\
\hline
\end{tabular}

\section{SIGNATURES}

\section{Approved by}
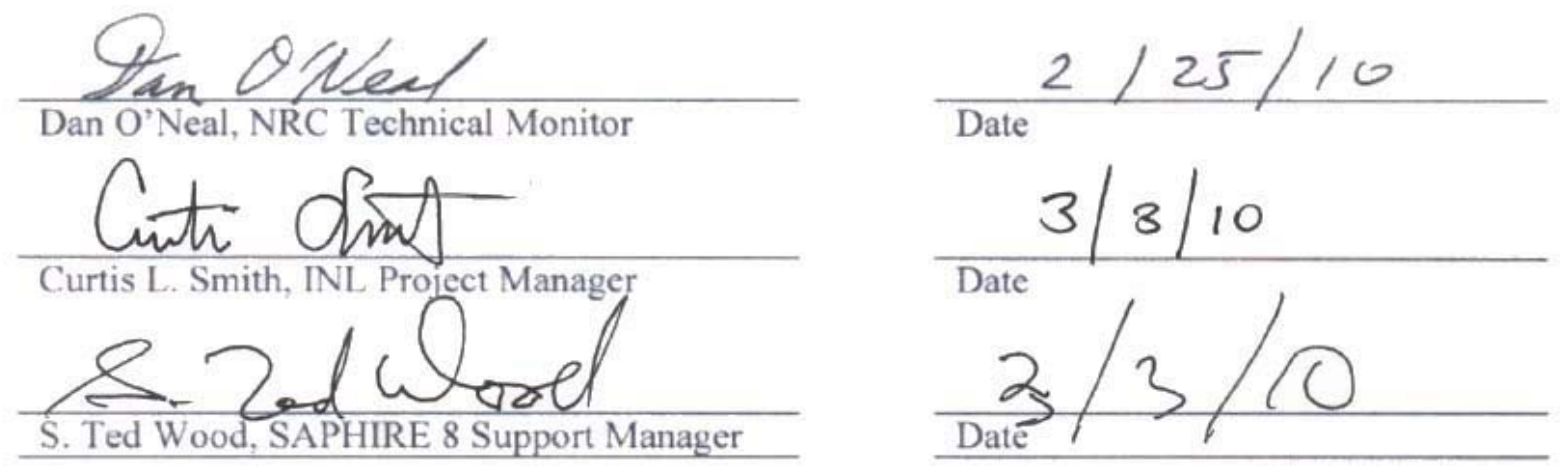


\begin{tabular}{|c|c|c|c|}
\hline Idaho National Laboratory & & & Page: 2 of 74 \\
\hline \multirow{3}{*}{$\begin{array}{l}\text { SOFTWARE PROJECT PLAN } \\
\text { for SAPHIRE Version } 8 \text { N6423 }\end{array}$} & Identifier: & INL/EXT-09-15853 & \\
\hline & Revision: & 4 & \\
\hline & Effective Date: & $3 / 3 / 2010$ & \\
\hline
\end{tabular}

\section{CONTENTS}

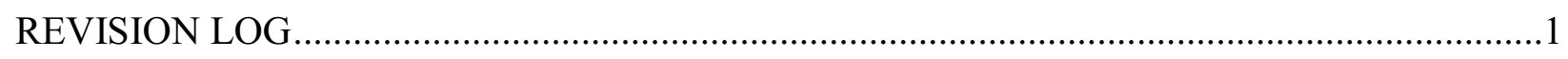

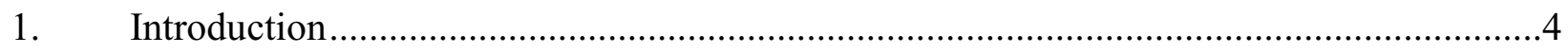

1.1 Project Background and Objectives .......................................................

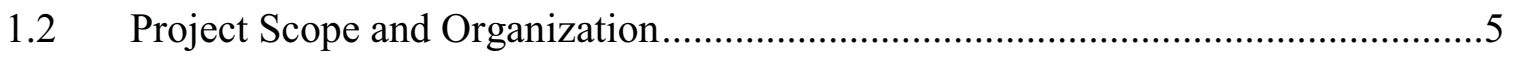

1.3 Plan Maintenance ..................................................................................... 10

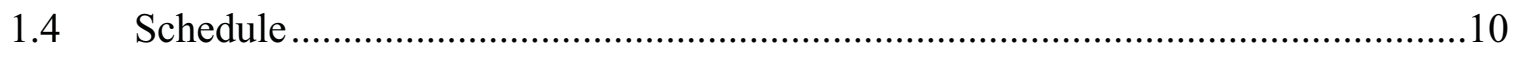

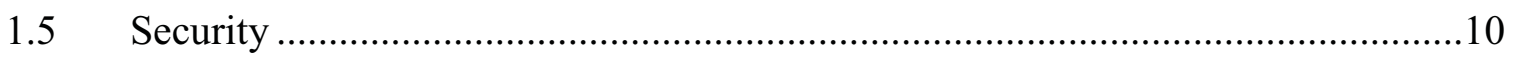

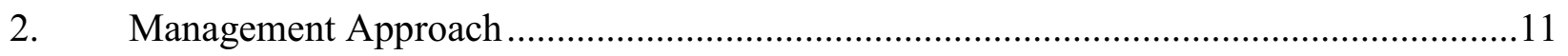

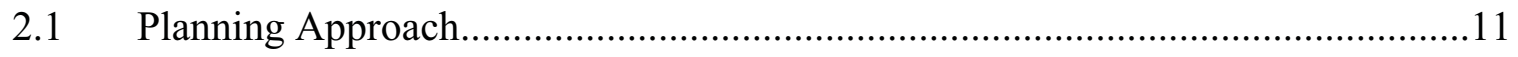

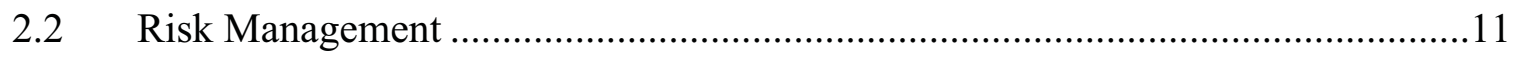

2.3 Tracking and Oversight Approach ............................................................... 12

$2.4 \quad$ Organization, Tasks, and Responsibilities ....................................................13

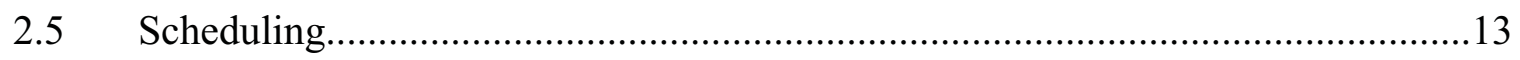

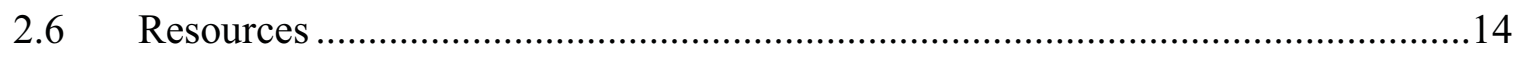

2.7 Configuration Management ................................................................... 15

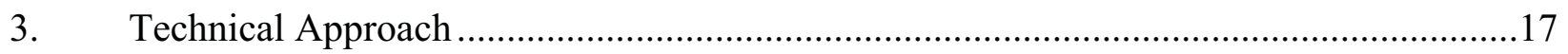

3.1 Implementing the Life Cycle Tasks of the Statement of Work ..........................17

3.2 Verification and Validation Approach.................................................... 17

3.3 Nonconformance Reporting and Corrective Action .....................................18

3.4 Peer Reviews and Code Walkthroughs.........................................................19

3.5 Quality Assessment (QA) and Improvement Approach ...................................21 


\begin{tabular}{|l|ll|}
\hline Idaho National Laboratory & \multicolumn{2}{l|}{ Page: 3 of 74} \\
\hline SOFTWARE PROJECT PLAN & Identifier: & INL/EXT-09-15853 \\
for SAPHIRE Version 8 N6423 & Revision: & 4 \\
\hline
\end{tabular}

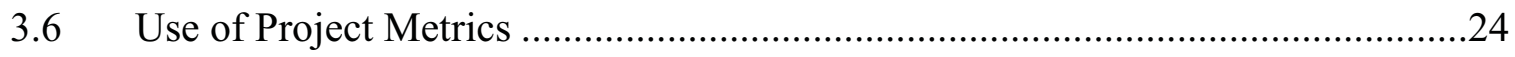

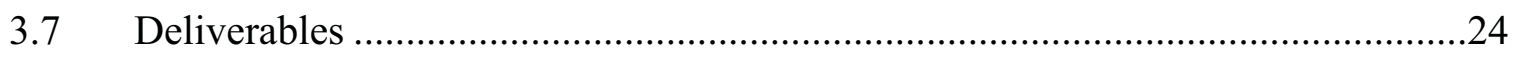

Appendix A SAPHIRE 8 Work Development Plan................................. 26

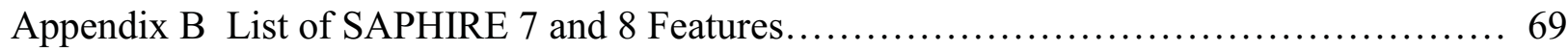

\section{FIGURES}

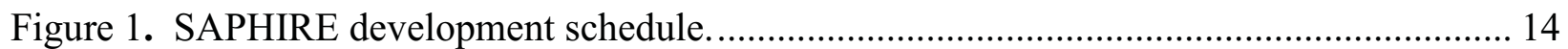

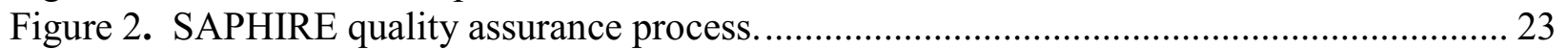

Figure 3. SAPHIRE 8 Release Management Process................................................................ 25

\section{TABLES}

Table 1. Summary of Major Life Cycle Reviews and Audits............................................... 19

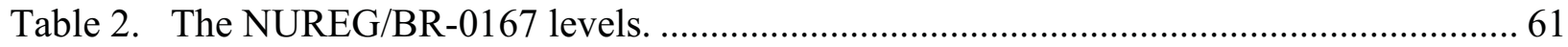

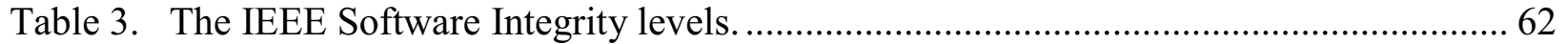

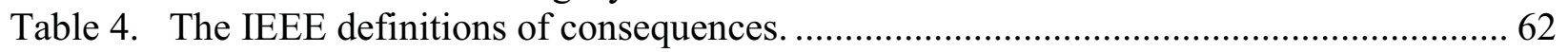

Table 5. The IEEE Software Integrity levels map onto the error consequence levels............... 63 


\begin{tabular}{|l|ll|}
\hline Idaho National Laboratory & Page: 4 of 74 \\
\hline SOFTWARE PROJECT PLAN & Identifier: & INL/EXT-09-15853 \\
for SAPHIRE Version 8 N6423 & Revision: & 4 \\
& Effective Date: & $3 / 3 / 2010$ \\
\hline
\end{tabular}

\section{Introduction}

\subsection{Project Background and Objectives}

The Atomic Energy Act of 1975 replaced the U.S. Atomic Energy Commission with the U.S. Nuclear Regulatory Commission (NRC) and the U.S. Energy Research and Development Administration (ERDA, the predecessor to the Department of Energy). Since that time, the National Laboratories have had the mission to support the NRC with engineering services. Objective 7 of the Idaho National Laboratory (INL) Strategic Plan calls for the INL to "establish a vital energy security business." The work for the NRC is a significant element of providing nuclear energy security for the nation.

This Software Project Plan (SPP) documents the technical work-scope that will be managed by the INL related to JCN N6423.

The NRC developed the SAPHIRE computer code for performing probabilistic risk assessments (PRAs) using a personal computer (PC) at the Idaho National Laboratory (INL) under Job Code Number (JCN) L1429. SAPHIRE started out as a feasibility study for a PRA code to be run on a desktop personal PC and evolved through several phases into a state-of-the-art PRA code. The developmental activity of SAPHIRE was the result of two concurrent important events: The tremendous expansion of PC software and hardware capability of the 90s and the onset of a riskinformed regulation era.

Three SAPHIRE versions have been released to date. Version 5 was a DOS version that became a production code a number of years ago. Version 6 was a Windows NT version that became a production code in 1998. Version 7 is also a Windows NT (or above) version that is currently the standard that is being used by the NRC.

Work began on a new version of SAPHIRE, Version 8, under JCN Y6394, "Maintenance and User Support for SAPHIRE Code and Library of PRAs." Version 8 is being designed to meet current NRC program needs such as those related to SPAR model development, the Significance Determination Process (SDP) program, the Risk Assessment Standardization Project (RASP), as well as the Accident Sequence Precursor (ASP) Program. Development of Version 8 continued under JCN N6203, "Maintain and Support SAPHIRE Code and Library." JCN N6423 "SAPHIRE Version 8" will support the beta and final Version 8, testing, verification, and validation.

The development of the new SAPHIRE version includes new features and capabilities. These features and capabilities are related to working with larger, more complex models and improving the user-friendliness of SAPHIRE's interfaces while retaining key functionality of Version 7.

Version 8 is being developed to support the Standard Plant Analysis Risk (SPAR) models and to run them as an integrated model (e.g., Level 1 with external events). The graphical user interface has also improved from SAPHIRE 7 to support NRC programs such as the SDP and the ASP. A 


\begin{tabular}{|l|ll|}
\hline \multicolumn{2}{|l|}{ Pdaho National Laboratory } & \multicolumn{2}{l|}{ Page 74} \\
\hline SOFTWARE PROJECT PLAN & Identifier: & INL/EXT-09-15853 \\
for SAPHIRE Version 8 N6423 & Revision: & 4 \\
& Effective Date: & $3 / 3 / 2010$ \\
\hline
\end{tabular}

tailored interface for the SDP and the ASP programs is being developed. An interface for general analyses and model construction is also being developed. The interfaces for the SDP, ASP, and general analysis introduce the concept of a "workspace" in which the analyst may run and save different analyses. The use of workspaces enables the user to separate the model construction from the model analysis.

Other features and capabilities added to the new version of SAPHIRE include the following. Size limitations have been removed on the number of basic events, fault trees, sequences, end states, etc. Work group integration capability has been added, allowing analysts to work on different model portions and integrate them to construct a large integrated model. Version 8 has also been tested on a multiple processor computer to study improving the speed of calculations.

In JCN N6423, a work plan will be developed to identify the work needed to complete a SAPHIRE 8 version for beta testing and to finalize the code for general release.

Projects JCN L1429 and JCN W6241 were closed out at the end of their periods of performance, November 30, 2000, for both projects. The remaining work from these two projects was consolidated into JCN Y6394, which has been closed out. JCN N6203 continues work on the current version of SAPHIRE, Version 7. Work is now being continued under JCN N6423 for SAPHIRE Version 8.

\subsection{Project Scope and Organization}

The INL may perform a wide range of engineering and research projects supporting all Offices under the NRC's Executive Director for Operations. Areas of specific expertise that the NRC has historically relied upon the INL to provide include probabilistic risk assessment, reliability analysis, operational data collection and trending, operational event assessment, component engineering, and training. Support in new technical areas is constantly being pursued.

All NRC work assigned to a DOE national lab is governed by NRC Directive 11.7, NRC Procedures for Placement and Monitoring of Work with the Department of Energy. The NRC assigns each project a unique Job Code Number (JCN), is funded separately, and is assigned a NRC Project Manager and NRC Technical Monitor. NRC Directive 11.7 establishes a controlled and monitored process for requesting services of a national lab, work planning, work authorization and initiation, work progress monitoring, reporting, work termination and project closeout. The primary documents to accomplish these functions are: Request for Proposal with attached Statement of Work, NRC Form 189 (DOE Laboratory Project and Cost Proposal for NRC Work), NRC Form 173 (Standard Order for DOE Work), and the Monthly Letter Status Report.

A detailed description for each project is established, documented, and approved by the NRC and DOE-ID on NRC Form 189. A summary description of each project is provided on the Control Account. These two documents provide the official project descriptions. All other project 


\begin{tabular}{|l|ll|}
\hline \multicolumn{2}{|l|}{ Pdaho National Laboratory 6 of 74} \\
\hline SOFTWARE PROJECT PLAN & Identifier: & INL/EXT-09-15853 \\
for SAPHIRE Version 8 N6423 & Revision: & 4 \\
& Effective Date: & $3 / 3 / 2010$ \\
\hline
\end{tabular}

management documents should refer to one of these two documents for a description.

The work scope for each JCN is provided in detail in the individual project's current NRC Form 189. All other project management documents should refer to the 189 for work scope.

The organizational structure of the SAPHIRE software development team influences and controls the software quality. Roles and responsibilities within the organizational structure provide the development team with the freedom, flexibility and objectivity to evaluate and monitor the software quality as well as verify problem resolutions. This structure enables the development team to tailor the maintenance and development activities, techniques, and methodologies for problem identification, reporting and resolution, testing, records retention, and configuration management.

For the INL, Software Quality Assurance (SQA) requirements are contract driven and interpreted from DOE Order 414.1C, "Quality Assurance", 10 CFR 830 Subpart A, "Quality Assurance Requirements", and ASME NQA-1-2000, "Quality Assurance Requirements for Nuclear Facility Applications." The INL internal document, PDD-13610, "Software Quality Assurance Program," describes the SQA Program at the INL. To implement the SQA Program, two supporting documents are used at the INL:

1. LRD-13600, "Software Quality Assurance" specifies the requirements and responsibilities for controlling the quality of software and applies to laboratory organizations that develop, procure, modify, maintain, operate, use, or retire software.

2. LWP-13620, "Software Quality Assurance" is the entry-level document for the SQA work processes. This procedure directs the SQA activities during the software life cycle which consists of requirements, design, implementation, acceptance test, operations, maintenance, and retirement. LWP-13620 is designed to standardize the lab's SQA implementation by applying a graded approach and utilizing trained personnel in the identification of the required SQA activities. LWP-13620 provides direction in determining the rigor (level of effort) required when (a) performing SQA activities and (b) creating documentation for each phase of the software life cycle.

SQA must be applied to all INL software (including SAPHIRE development) activities that meet the criteria in LWP-13620. Performing SQA is important because it (a) maintains compliance with DOE O 414.1C, "Quality Assurance" and 10 CFR 830 "Nuclear Safety Management", Subpart A "Quality Assurance Requirements"; (b) assists in assuring you are following a stable, repeatable process that is cost effective and consistently meets customer requirements; and (c) provides a foundation for ensuring the quality of software developed, procured, and modified at the INL.

Per PDD-13610, the Software Owner is a representative of the organization responsible for the application of the software. He/she is identified in the INL Enterprise Architecture and is responsible for: 


\begin{tabular}{|l|ll|}
\hline Idaho National Laboratory & Page: 7 of 74 \\
\hline $\begin{array}{l}\text { SOFTWARE PROJECT PLAN } \\
\text { for SAPHIRE Version 8 N6423 }\end{array}$ & Identifier: & INL/EXT-09-15853 \\
& Revision: & 4 \\
Effective Date: & $3 / 3 / 2010$ & \\
\hline
\end{tabular}

- Identifying and documenting the appropriate safety software categorization to software per LWP-13620.

- Approving software management plan, requirement, acceptance test, and retirement documentation

- Approving results of evaluations of acquired and legacy software to determine adequacy to support the operations, maintenance, and retirement phases

- Procuring software using LWP-4001, "Material Acquisitions" and LWP-4002, "Service Acquisitions."

- Developing and implementing program-specific training for the operational use of safety software

- Considering whether user training is needed for the operational use of Quality Level 1 and Quality Level 2 software.

"Software" as defined by the PDD-13610 procedure pertains to computer programs and associated documentation and data pertaining to the operation of a computer system and includes:

1. Application Software - software designed to fulfill specific needs of a user; for example navigation, payroll, or process control.

2. Support Software such as the following software tools (e.g., compilers, configuration and code management software, editors) or system software (e.g., operating systems).

Note that within the INL SQA process, software that does not fall within the scope of the SQA Program includes any software covered by a contractual agreement, such as Work for Others, that includes references or requires a specific documented SQA process. Currently, the SAPHIRE development does not reference or require a specific documented SQA process - thus the development falls under the INL SQA process.

It is the responsibility of the Software Owner to make the determination as to whether a particular software can be classified as "safety software." Safety Software includes the following type of software:

- Safety System Software. Software for a nuclear facility that performs a safety function as part of a structure, system, or component and is cited in either (a) a DOE approved documented safety analysis or (b) an approved hazard analysis per DOE P 450.4, Safety Management System Policy, dated 10-15-96, and the DEAR clause.

- Safety Analysis and Design Software. Software that is used to classify, design, or analyze nuclear facilities. This software is not part of a structure, system, or 


\begin{tabular}{|l|ll|}
\hline \multicolumn{2}{|l|}{ Pdaho National Laboratory 8 of 74} \\
\hline SOFTWARE PROJECT PLAN & Identifier: & INL/EXT-09-15853 \\
for SAPHIRE Version 8 N6423 & Revision: & 4 \\
& Effective Date: & $3 / 3 / 2010$ \\
\hline
\end{tabular}

component (SSC) but helps to ensure that the proper accident or hazards analysis of nuclear facilities or an SSC that performs a safety function.

- Safety Management and Administrative Controls Software. Software that performs a hazard control function in support of nuclear facility or radiological safety management programs or technical safety requirements or other software that performs a control function necessary to provide adequate protection from nuclear facility or radiological hazards. This software supports eliminating, limiting or mitigating nuclear hazards to worker, the public, or the environment as addressed in 10 CFR 830, 10 CFR 835, and the DEAR ISMS clause.

For all software that falls within the scope of the SQA Program, a quality level must be assigned by a qualified Quality Level Analyst with review and concurrence by a Quality Level Reviewer (i.e., a second Quality Level Analyst) per LWP-13014, "Determining Quality Levels." The Quality Level Analyst should then communicate to the Software Owner the determined quality level.

However, for software deployed prior to the release of the revised INL SQA Program (SAPHIRE development falls into this category):

1. When the revised INL SQA Program became effective $(3 / 29 / 2007)$, the date for completion of the QL determination for legacy software projects must be identified and documented.

2. At the time the software is modified, the QL determination activity must be performed.

3. ALL software must have an associated QL Determination by no later the $3 / 31 / 2008$.

A quality level is a designator that identifies the relative risk associated with the failure of items or activities. This quality level determination must be performed regardless of the size or complexity of the software. The Quality Levels are defined as follows:

Quality Level 1 software is software whose failure creates "high" risk. This software requires a high degree of rigor during the software life cycle.

Quality Level 2 software is software whose failure creates "medium" risk. This software requires a moderate degree of rigor during the software life cycle.

Quality Level 3 software is software whose failure creates "low" risk. This software requires a low degree of rigor during the software life cycle.

The quality level of the software is a component when determining the level of rigor (gradedapproach) that the SQA Specialist must ensure is applied when performing software quality assurance activities or creating documentation for each phase of the software life cycle. The 


\section{Idaho National Laboratory \\ SOFTWARE PROJECT PLAN \\ for SAPHIRE Version 8 N6423}

Page: 9 of 74

Identifier: $\quad$ INL/EXT-09-15853

Revision: $\quad 4$

Effective Date: $3 / 3 / 2010$

higher the quality level of the software, the more rigorous the quality assurance activities and documentation will need to be as defined in Section 4.2 of LWP-13620.

Per the Requirements Phase Documentation table in LWP-13620:

1. For QL-1 and QL-2 Custom-Developed or Configurable software: include within the software's documentation (e.g., Project Execution Plan (PEP), Software Quality Assurance Plan (SQAP)):

a. The activities to be performed to support software quality assurance (e.g., design reviews, acceptance testing, reviews and audits),

b. Identify SQA documentation to be generated,

c. Identify the roles and responsibilities for SQA activities, and

d. The methodology for tracing requirements throughout the software life cycle.

2. For QL-3 Custom Developed or Configurable software and all other software types (i.e., acquired, utility calculations, commercial D\&A), the described information is optional or not applicable within the software's documentation.

All documentation that furnishes evidence of the software quality is considered a QA record and should be handled as a quality record according to the organization, program, or project's Records Management Plan as required by LWP-1202. QA records generated during the software development life cycle could include project plans, requirement specifications, configuration management plans, software quality assurance plans, security plans, and verification and validation documentation (e.g., test plans, test cases, design review documents).

For the SAPHIRE 8 development project, the INL-derived QA program (LWP-13620) quality level has been set at Quality Level 3.

Note that the quality of NRC research programs are assessed each year by the Advisory Committee on Reactor Safeguards. Within the context of their reviews of Office of Research programs, the definition of quality research is based upon several major characteristics:

$75 \% \quad$ Results meet the objectives

$17 \%$ Justification of major assumptions (12\% of total)

$68 \%$ Soundness of technical approach and results (52\% of total)

$15 \%$ Uncertainties and sensitivities addressed (11\% of total)

$25 \%$ Documentation of research results and methods is adequate

$64 \%$ Clarity of presentation (16\% of total) 


\begin{tabular}{|l|ll|}
\hline Idaho National Laboratory & Page: 10 of 74 \\
\hline SOFTWARE PROJECT PLAN & Identifier: & INL/EXT-09-15853 \\
for SAPHIRE Version 8 N6423 & Revision: & 4 \\
& Effective Date: & $3 / 3 / 2010$ \\
\hline
\end{tabular}

$36 \%$ Identification of major assumptions ( $9 \%$ of total)

It is the responsibility of the contractor to ensure that these quality criteria are adequately addressed throughout the course of the research that is performed. The NRC PM and TM will review all research products with these criteria in mind.

INL will follow NRC Management Directive 11.7 "Procedures for Placement and Monitoring of Work with the Department of Energy" related to software development. This directive suggests that "all software development, modification, or maintenance tasks shall follow general guidance provided in NUREG/BR-0167 "Software Quality Assurance Program and Guidance."

SAPHIRE 8 will follow the requirements for Level 1 software defined in Section 1.2 of NUREG/BR-0167.

The NRC will perform an audit of the software QA implementation once a year against the requirement of NUREG/BR-0167.

\subsection{Plan Maintenance}

The SPP will be updated as needed as required by the NRC Project Management.

\subsection{Schedule}

At the INL, each JCN has its own project start and end dates prominently indicated on NRC Form 189 and NRC Form 173. Additionally, specific tasks within the work scope will also have start and end dates along with a schedule for deliverables listed in the NRC Form 189.

\subsection{Security}

This project in itself is unclassified. However, some PRAs may include proprietary or company confidential information. If proprietary or company confidential information is involved, the INL agrees to safeguard such information in accordance with 10 Code of Federal Regulations (CFR) 2.790. The INL agrees to not release such information to any person not directly involved in the performance of work under this contract, unless such release is authorized in writing by the NRC PM. Upon completion or termination of the contract, all data and information (hardcopy or electronic media) classified as proprietary or company confidential will be returned to the NRC.

Currently, the NRC reviews and approves SAPHIRE requests on a case-by-case basis. 


\begin{tabular}{|l|ll|}
\hline Idaho National Laboratory & \multicolumn{2}{c|}{ Page: 11 of 74 } \\
\hline SOFTWARE PROJECT PLAN & Identifier: & INL/EXT-09-15853 \\
for SAPHIRE Version 8 N6423 & Revision: & 4 \\
& Effective Date: & $3 / 3 / 2010$ \\
\hline
\end{tabular}

\section{Management Approach}

\subsection{Planning Approach}

Overall Project Control and Reporting for NRC work is governed by NRC Directive 11.7. The process starts when the NRC sends DOE-ID a Request for Proposal and Statement of Work (SOW). DOE-ID will then forward these two documents to the INL Program Manager (in the NRC processes, the Program Manager is called the Laboratory Project Manager). The Program Manager will assure that the NRC Customer Relationship Manager is sufficiently informed of the proposed work to meet the requirements of the NRC organizational conflict of interest (OCOI) Mitigation Plan. The INL Program Manager will assign the proposal to a prospective PI to plan the work and prepare a proposal.

The SOW provides all the pertinent information required for the PI to prepare an NRC Form 189 proposal: Project Title, JCN, Budget and Reporting number, NRC issuing office, NRC Project Manager's name and contact information, NRC Technical Monitor's name and contact information, project background, project objectives, scope of work, deliverables and schedules, period of performance, reporting requirements, and so on.

Using this information, the PI, assisted by the PCFS, will prepare a baseline work scope, schedule, and cost estimate as described in Sections 1.3 through 1.5 above. These elements will be documented on NRC Form 189 in accordance with NRC Directive 11.7. The NRC Form 189 will be reviewed by the PFCS and INL Program Manager and signed by the INL Program Manager before transmittal to the DOE-ID Project Manager for review and forwarding to the NRC.

Upon acceptance of the INL proposal, the NRC Office over the work will issue an NRC Form 173, Standard Order for DOE Work to DOE-ID with the INL PI on distribution. The DOE-ID Project Manager indicates acceptance of the NRC Form 173 by signature and returns the signed form back to the NRC with copies to the INL PI and Program Controls and Financial Services (PCFS). The PFCS or PI provides a copy of the signed NRC Form 173 to the Program Manager. The signed NRC Form 173 authorizes the transfer of funds from the NRC to DOE-ID and serves as the official authorization to commence work, equivalent to the DOE-ID Work Authorization Form, the Project Authorization Document (INL Form 415.03) and the Project Work Authorization Document (INL Form 415.09). The PCFS organization will issue a Funds Authorization Form to the Program Manager, indicating that the funds have been entered into the INL financial tracking systems. The Program Manager forwards the Funds Authorization Form to the PI to retain in the Project Records file.

\subsection{Risk Management}

Prior to starting the SAPHIRE 8 development project, an INL Proposal Risk and Evaluation Preparation System (PREPS) entry was created (PREPS ID: 0807-C.C-41-000454). The results 


\begin{tabular}{|l|ll|}
\hline Idaho National Laboratory & Page: 12 of 74 \\
\hline SOFTWARE PROJECT PLAN & Identifier: & INL/EXT-09-15853 \\
for SAPHIRE Version 8 N6423 & Revision: & 4 \\
& Effective Date: & $3 / 3 / 2010$ \\
\hline
\end{tabular}

of this evaluation indicated that the SAPHIRE 8 development project was low management risk. The applicable original PREPS document is stored in the INL electronic documentation system in addition a copy has been stored in the SAPHIRE 8 revision control system (RCS). The PREPS for SAPHIRE 8 was approved by INL management on October 31, 2007.

\subsection{Tracking and Oversight Approach}

Work scope management is maintained through the NRC Directive 11.7 process. All revisions to the work scope are documented on NRC Form 189 and accepted by a signed NRC Form 173. Each NRC Form 189 is assigned a Revision number for tracking and reference purposes.

The task-oriented schedule and budget for each project is established by the PI in conjunction with the financial controls person. The PI will determine if there is a need to re-baseline the schedule and/or budget.

The PI also serves as the Control Account Manager (CAM) and Work Package Manager. Each NRC project will have one Control Account and one Work Package. The PI will develop the control account and work package, referring to the current NRC Form 189 as often as possible. The PI will schedule and direct internal review meetings.

The NRC requires that schedule and cost variances be identified and reported in the Monthly Letter Status Report (MLSR). For reporting purposes, only the actual cost variance in dollars and schedule variance in calendar time are required. Variances greater than $\$ 10 \mathrm{~K}$ or ten percent of the project annual budget (whichever is larger) require an explanation of the impacts on the project and any corrective actions necessary. Internally, the cost performance index (CPI) and schedule performance index (SPI) are calculated and reported.

The accomplishment of project milestones and delivery of project deliverables are documented in transmittal letters and/or in the MLSR as directed by the NRC Project Manager and Technical Monitor.

If at any time it is determined that a subcontractor or consultant is required to assist the SAPHIRE development, the following would be provided in writing to the NRC PM for approval before procuring such assistance:

- The proposed subcontractor.

- The necessity of subcontracting.

- The tasks and subtasks the subcontractor will perform.

- $\quad$ The level of effort proposed.

- The status and expected time for selection.

- The method of selection of the subcontractor or consultant. 


\begin{tabular}{|l|ll|}
\hline Idaho National Laboratory & Page: 13 of 74 \\
\hline SOFTWARE PROJECT PLAN & Identifier: & INL/EXT-09-15853 \\
for SAPHIRE Version 8 N6423 & Revision: & 4 \\
& Effective Date: & $3 / 3 / 2010$ \\
\hline
\end{tabular}

\subsection{Organization, Tasks, and Responsibilities}

Battelle Energy Alliance, LLC, as the contractor managing and operating the INL, has teaming partners that have the potential to present an organizational conflict of interest (OCOI) with work for the NRC. Therefore, the INL has in place an OCOI Mitigation Plan to allow work for the NRC. In accordance with that Plan, all NRC work will be managed within the Nuclear Programs Directorate. For projects under this PEP, the Program Manager is the C210 Department Manager. The Program Manager assigns a PI to each JCN. The PI requests team members from the Program Manager, who makes the final project assignments. The PI makes all technical and administrative work assignments to the project team members. The core project team is documented on the NRC Form 189. In addition to the core project team, a PCFS will be assigned to the project and administrative support will provided by the Nuclear Programs office specialist pool.

As SAPHIRE 8 is currently in the development phase of the software development lifecycle, software development procedures and supporting company standards are tailored to provide an appropriate level of quality, based upon a graded approach. The graded approach integrates the following INL software management processes, standard, and procedures:

- Software Management which identifies responsibilities, development methodologies, tools, and deliverables

- Quality Assurance activities to assure that the final software application meets the customer needs for quality and timeliness

- $\quad$ Configuration Management and Change Control to monitor and uniquely identify baselines, changes that are requested, evaluated, approved, and tested, as well as backup and recovery actions

- $\quad$ Software defect reporting and resolution for promptly addressing and resolving software errors

- $\quad$ Maintenance of the software to remove latent errors (corrective maintenance), respond to new or revised requirements (preventive maintenance), and to adapt to software changes in the operating environment (adaptive maintenance)

- $\quad$ Requirements and Design activities identified in contract documents

- $\quad$ Testing activities, including automated test scripts and results identified in the SAPHIRE Verification and Validation Plant (SVVP) document. These test procedures demonstrate the adherence to the requirements specified in the NRC forms.

- $\quad$ Recording and implementing lessons learned

\subsection{Scheduling}

Schedules for development work to be performed are documented in the project NRC Form 189. Schedules are identified for individual tasks and negotiated with the NRC PM. The N6423 Form 


\begin{tabular}{|l|ll|}
\hline Idaho National Laboratory & Page: 14 of 74 \\
\hline SOFTWARE PROJECT PLAN & Identifier: & INL/EXT-09-15853 \\
for SAPHIRE Version 8 N6423 & Revision: & 4 \\
& Effective Date: & $3 / 3 / 2010$ \\
\hline
\end{tabular}

189s and 173s provide the current schedule for beta releases and the first release of Version 8 for general use. This schedule is illustrated below in Figure 1:

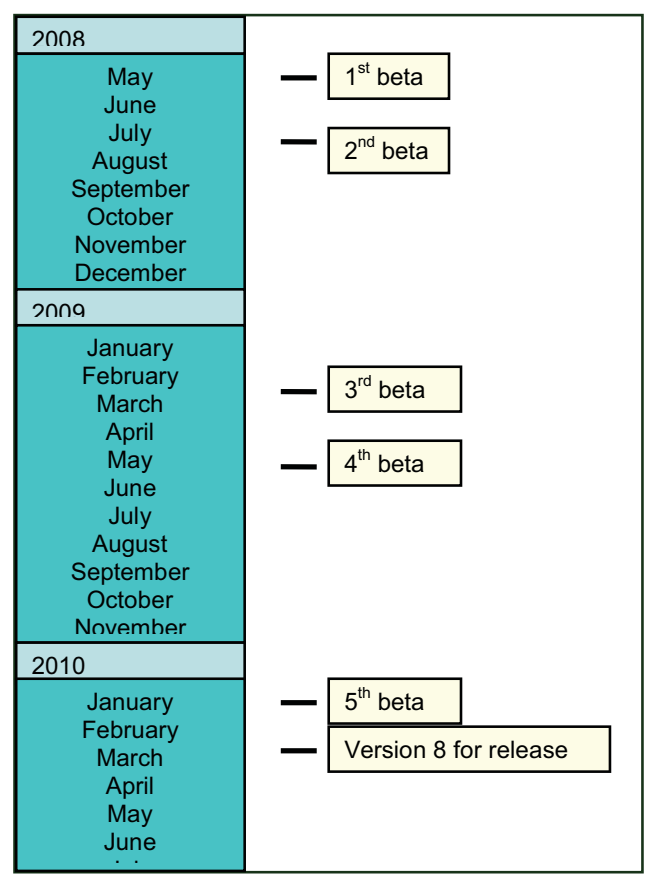

Figure 1. SAPHIRE development schedule.

Budgetary control of the schedule is provided by an internal INL work breakdown structure (WBS) that is maintained and modified by INL planning and financial control specialists. Supporting the WBS is a budget Basis of Estimate document that reflect the level of effort specified in the NRC Form 189 for the project.

\subsection{Resources}

A weekly financial status report is prepared for all projects and is distributed to the PIs and Program Manager by the PCFS. This report provides current status of funds expended and funds available. A monthly Cost Performance Report is provided by the PCFS from current information in IPS2000. This report provides the cost performance index and schedule performance index for both the current fiscal month and year-to-date for each individual project and for WBS Level 5. It also provides the latest Estimate at Completion (EAC). This report is distributed to the NRC Customer Relationship Manager and Program Manager and is reviewed in the monthly Business Review Meeting.

All NRC work is under the supervision and direction of the Nuclear Safety and Regulation Division Director who serves as the NRC Customer Relationship Manager. The Risk, Reliability and NRC Programs Department (C210) Manager serves as the Program Manager for all NRC 


\begin{tabular}{|l|ll|}
\hline Idaho National Laboratory & Page: 15 of 74 \\
\hline SOFTWARE PROJECT PLAN & Identifier: & INL/EXT-09-15853 \\
for SAPHIRE Version 8 N6423 & Revision: & 4 \\
& Effective Date: & $3 / 3 / 2010$ \\
\hline
\end{tabular}

work assigned to that department. Each JCN is assigned a senior technical staff member within the C210 department as the PI. PIs of larger JCNs may designate Task Leaders, as appropriate.

Most JCNs do not require external interfaces beyond those with the DOE-ID representative and the NRC Project Manager and Technical Monitor. Should there be a need for subcontractors, the NRC will approve before any subcontracts are let and all subcontracts will be documented on NRC Form 189.

Routinely, a JCN may require expertise not found within Department C210. Internal laboratory interfaces with experts in human reliability, thermal hydraulics, severe accident analysis, seismic and structural analysis, among others, is common. The PI for each JCN will determine the need and arrange and manage the interfaces.

Developers of the SAPHIRE team need to be familiar with DELPHI C Version 7 IDE, Modula-2 IDE, DOS batch files and scripting, and use of the Microsoft Windows platforms to support the interface upgrade and the functional improvement development and testing effort.

The management of the project is controlled by the PI. Changes in the PI assignment will be requested by formal letter to the NRC and will not take place until NRC concurrence is received. Personnel from the INL's Risk, Reliability, and NRC Programs Department shall be responsible for risk assessment support and for development and maintenance of the SAPHIRE software. Resumes for those persons expected to work on JCN N6423 will be made available to the NRC PM separate from this Form 189. Staffing level is based according to the level of work identified in the NRC Form 189.

The INL shall provide additional resumes for any personnel that works on JCN N6423 for whom the NRC PM does not have a resume on file.

\subsection{Configuration Management}

Records Management will be performed for all NRC projects in accordance with LWP-1201 (Document Management), LWP-1202 (Records Management), and the Records Management Plan for Nuclear Programs, PLN-2224.

The INL software developers use version control for both the formally released SAPHIRE versions, as well as for source code. For each formal release of the software, the developers perform an acceptance test: the software must pass a suite of automated tests prior to official release. IV \&V tests and test observations are also being performed as given in the IV\&V plan to support the first general release version of SAPHIRE 8.

Each official release of SAPHIRE is assigned a unique version identifier. The release is bundled into a standard installation package for easy and consistent set-up by individual users. Included in the release is a list of bug fixes and new features for the current release, as well as a history of 


\begin{tabular}{|l|ll|}
\hline Idaho National Laboratory & Page: 16 of 74 \\
\hline SOFTWARE PROJECT PLAN & Identifier: & INL/EXT-09-15853 \\
for SAPHIRE Version 8 N6423 & Revision: & 4 \\
& Effective Date: & $3 / 3 / 2010$ \\
\hline
\end{tabular}

those items for past releases. Each formal release of SAPHIRE will have passed an acceptance test described in the Software Acceptance Test Plan (INL/EXT-09-16236).

In addition to assignment of a unique version identifier for an official software release, each source code file is kept in a controlled library (a revision control system, or RCS). (Source code is a collection of all the computer instructions written by developers to create the finished product.) The library is kept on a server, where back-ups are regularly made. (Individual developers/programmers machines are periodically backed up as well.)

The source code version control library requires that individual programmers "check-out" all files that they intend to modify. Prior to "check-in", programmers must document changes. A record is kept of all changes, both as explained by the developer, and as individual copies of each version of a file. At any time, the developer can retrieve past versions intact, if necessary.

The SAPHIRE software program is continually modified, in response to user reported bugs and suggestions, and contractually specified enhancements. The version control procedure described above ensures a methodical approach to tracking and releasing these changes.

Quality assurance reviews configuration management and control processes to ensure that only authorized changes are made to the software. All software modules that have been tested, documented, and approved for inclusion into the next release of the software are baselined. The software/system database "librarian" controls the baselined source code. Copies of current build routines needed to construct the software, including all copies of all build routines used in all prior releases are also under the librarian control.

SAPHIRE uses a configuration management database as a control library for all information related to the development of software fixes, enhances, baselines, and subsequent releases. Processes are in place to uniquely identify all components, modules, documentation, error reports, test suites, and test results through the establishment of a configuration control tracking number. The control library is kept on a server, where back-ups are regularly made. (Individual developers/programmers machines are periodically backed up as well). Controls are in place to preclude multiple users from simultaneously accessing the same information. A source code version control library requires that individual programmers "check-out" all files that they intend to modify. Prior to "check-in", programmers must document any changes made. A record is kept of all changes, both as explained by the developer, and as individual copies of each version of a file. At any time, the developer can retrieve past versions intact, if necessary. The SAPHIRE software program is continually modified, in response to user reported bugs and suggestions, and contractually specified enhancements. The version control procedure ensures a methodical approach to tracking and releasing these changes.

Software enhancements and supporting requirements and documentation are also placed under configuration control. Enhancements are prioritized and implemented, with intermediate testing by the developer and often by the requestor. Once the process and results appear acceptable, the feature is added to the next official release. 


\begin{tabular}{|l|ll|}
\hline Idaho National Laboratory & Page: 17 of 74 \\
\hline SOFTWARE PROJECT PLAN & Identifier: & INL/EXT-09-15853 \\
for SAPHIRE Version 8 N6423 & Revision: & 4 \\
& Effective Date: & $3 / 3 / 2010$ \\
\hline
\end{tabular}

\section{Technical Approach}

\subsection{Implementing the Life Cycle Tasks of the Statement of Work}

Management provides oversight activities as well as monthly status reports, draft reports, and a final report of the development activities that are performed. The SAPHIRE principal investigator directs the roles, responsibilities, and tasks of the software development team. Many of the quality management tasks and activities are conducted by product teams but are also reviewed by the principal investigator.

To assist in managing the technical work, a SAPHIRE-specific Work Development Plan has been developed that guides the general aspect of the work. The most current version of this plan is shown in Appendix A. Note that the NRC Form 189 show the actual contracted work.

In addition to the Work Development Plan, an extensive discussion of the Software Requirement have been specified in the applicable NRC Form 189 and the SVVP document. Sections 2, 3, and 4 discuss software and platform interface requirements, describing at high-level the design of the main functional areas and what they do. For details of the technical implementation, the reader should refer to these sections of the SVVP.

QA-related documentation for the project should adhere to standards identified in NUREG/BR0167, "Software Quality Assurance Program and Guidelines." Technical documentation to be published as a NUREG/CR follows guidance in NUREG-0650, Revision 2, "Preparing NUREGSeries Publications."

\subsection{Verification and Validation Approach}

A SVVP document is used to make sure that all requirements ${ }^{1}$ are implemented and those new features do not affect existing code functionality or design. The SVVP is a consolidated document used for tracking the software development, testing and implementation and explicitly identifies the new features implemented for each release of the software as well as the automated test results, including regression tests, to ensure the software is complete, consistent, and correct. The SAPHIRE product development team uses the SVVP to track, verify and validate requirements to ensure that all requirements are implemented and that all requirements are included in the automated test scripts and test results. The SVVP plan is updated for each release of SAPHIRE by the development team by the performance of the following steps:

- $\quad$ Prepare the SVVP

- $\quad$ Determine the areas required for testing, including regression testing

\footnotetext{
1 "All requirements" refers to the requirements specifications in the requirements traceability matrix.
} 


\begin{tabular}{|l|ll|}
\hline Idaho National Laboratory & Page: 18 of 74 \\
\hline SOFTWARE PROJECT PLAN & Identifier: & INL/EXT-09-15853 \\
for SAPHIRE Version 8 N6423 & Revision: & 4 \\
& Effective Date: & $3 / 3 / 2010$ \\
\hline
\end{tabular}

- Develop new test cases based upon the development of a test model that includes the identification of available PRA obtained from the PRA database

- $\quad$ SVVP model testing which encompasses the identification of base-case or nominal results for each test case

- Documenting the test results, conclusions, and actions to correct any failures discovered during the automated testing process

Models, with varying degrees of size and complexity, based on suitability for adequately testing one or more critical functions are then selected. These models mainly consist of actual PRA models developed by experienced analysts. Test scripts have been developed to exercise essential SAPHIRE functions, with a quantitative emphasis. New test scripts are developed for software enhancements, as needed. These test scripts mimic actions taken by an analyst, such as starting SAPHIRE and navigating the user interface by selecting menu options, clicking buttons and typing information. Results are saved and compared against expected results. A summary and a detailed report of the results of the tests are produced, so that an overview of the results can quickly be determined, and any failures (or successes) can be traced in more detail.

\subsection{Nonconformance Reporting and Corrective Action}

NRC Form 189 stipulates the requirements for a MLSR from the INL to the NRC for each JCN. NRC Directive 11.7 provides guidance and format for the MLSR. Included in the MLSR: project objectives, progress during the reporting period, anticipated and encountered problem areas, travel, plans for the next reporting period, schedule and cost variances, financial status, and spending plan updates. The DOE-ID Project Manager is on distribution for the MLSR.

Project-level nonconformance and associated corrective actions will be reported to the NRC via the MLSR. Testing- and QA-related nonconformances are reported through the SVVP and the Change Request tracking systems. For testing, the entrance criteria for testing are to obtain the stored test repository and associated project databases from the RCS. The test scripts are exercised as noted in the script. The exit criteria for testing are to check the suite test output results file for any failed tests. Note that one test has been designed to always fail and is used as a "false positive" results to ensure functionality of the designed comparison against the QA benchmarked results. When a problem is corrected, it will be tested. A change is not considered complete until the results have been tested and found reasonable. Developers and key users will test to see that the change works as expected and is free of defects. Prior to official release of a version, the SAPHIRE Version 8 tests in the Acceptance Test Plan must complete successfully.

An impact assessment will be conducted by the development team for all medium and high severity nonconformances. These assessments will be made available to the NRC. 


\title{
SOFTWARE PROJECT PLAN for SAPHIRE Version 8 N6423
}

\author{
Identifier: INL/EXT-09-15853 \\ Revision: $\quad 4$ \\ Effective Date: $3 / 3 / 2010$
}

\subsection{Peer Reviews and Code Walkthroughs}

As part of the SAPHIRE 8 development, the team will perform and document, as appropriate, periodic peer reviews and code walkthroughs, including reviews of preliminary and critical designs proposals. Since non-conformances are reported and logged through the SAPHIRE Change Request tracking system, medium and high priority reports will be reviewed (and the review documented).

Peer reviews and code walkthroughs will be reviewed independently when possible by IV\&V members. The guidance for external peer reviews is found in the NRC's office instruction, PRM-10, Revision 0, "Peer Review of RES Projects," dated March 19, 2007. NRC is performing an internal peer review, and not an external peer review for the first release of SAPHIRE 8. The NRC SAPHIRE users also test and comment on SAPHIRE code modifications. In addition, NRC performs audits against NUREG/BR-0167 for SAPHIRE.

Table 1. Summary of Major Life Cycle Reviews and Audits.

\begin{tabular}{|c|c|c|c|}
\hline $\begin{array}{c}\text { Major Life } \\
\text { Cycle Activity }\end{array}$ & $\begin{array}{c}\text { Formal Reviews and } \\
\text { Audits }\end{array}$ & Product (e.g., Version 8) & $\begin{array}{l}\text { Modules (e.g., specific } \\
\text { requirements for Version 8) }\end{array}$ \\
\hline $\begin{array}{l}\text { Requirements } \\
\text { Definition }\end{array}$ & $\begin{array}{l}\text { Software } \\
\text { Requirements Review }\end{array}$ & $\begin{array}{l}\text { Requirements specified from } 2002 \text { through } \\
2009 \text { for the first release of Version } 8 \text {. } \\
\text { The first Version } 8 \text { software is due March } \\
2010 \text {. } \\
\text { Later releases of Version } 8 \text { are anticipated } \\
\text { to address additional requirements. No } \\
\text { date(s) for later releases of Version } 8 \text { are } \\
\text { currently specified. }\end{array}$ & $\begin{array}{l}\text { Schedule is dependent on when } \\
\text { the requirement is specified. } \\
\text { Many requirements are staggered } \\
\text { over time due to when user needs } \\
\text { are specified. The Form } 189 \mathrm{~s} \\
\text { contain schedules for a number of } \\
\text { requirements. Other schedules } \\
\text { may come from user comments, }\end{array}$ \\
\hline Design & $\begin{array}{l}\text { Preliminary Design } \\
\text { Review (PDR) } \\
\text { Critical Design } \\
\text { Review (CDR) }\end{array}$ & $\begin{array}{l}\text { Due to the nature of the timing of } \\
\text { requirements specifications, a PDR and a } \\
\text { critical design review for the whole of } \\
\text { Version } 8 \text { is difficult to schedule. These } \\
\text { types of reviews are easier to schedule for } \\
\text { the design and implementation of code } \\
\text { modules (next column). The sponsor, the } \\
\text { NRC, may conduct a peer review } \\
\text { according to their peer review guidance } \\
\text { for review of the product as a whole. } \\
\text { Note that improvements to review } \\
\text { processes and documentation in PDRs and } \\
\text { CDRs may be considered in the future. }\end{array}$ & $\begin{array}{l}\text { Schedules for these types of } \\
\text { reviews depends upon when the } \\
\text { requirements are received by the } \\
\text { SAPHIRE development team. } \\
\text { PDRs and CDRs include: } \\
\text { - INL SAPHIRE } \\
\text { development team } \\
\text { reviews } \\
\text { - Sponsor reviews of the } \\
\text { designs }\end{array}$ \\
\hline Implementation & $\begin{array}{l}\text { Qualification Test } \\
\text { Readiness Review }\end{array}$ & $\begin{array}{l}\text { The product is to pass the Acceptance Test } \\
\text { Plan to support release of Version } 8 \\
\text { in April 2010. The Acceptance Test Plan } \\
\text { will be used to support later releases of } \\
\text { SAPHIRE Version } 8 \text { also. }\end{array}$ & $\begin{array}{l}\text { The code undergoes testing by } \\
\text { the SAPHIRE development team } \\
\text { in accordance with the } \\
\text { requirement's schedule. The } \\
\text { schedule may be specified in the }\end{array}$ \\
\hline
\end{tabular}




\section{Idaho National Laboratory \\ SOFTWARE PROJECT PLAN for SAPHIRE Version 8 N6423}

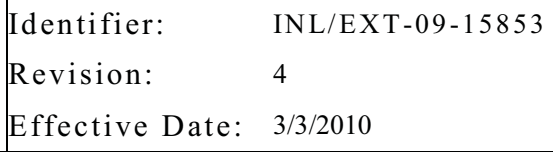

\begin{tabular}{|c|c|c|c|}
\hline & & $\begin{array}{l}\text { Note that improvements to review } \\
\text { processes and documentation in PDRs and } \\
\text { CDRs may be considered in the future. }\end{array}$ & $\begin{array}{l}\text { Form } 189 \text { for a specific } \\
\text { requirement or for a next release } \\
\text { of the software to support user } \\
\text { needs. }\end{array}$ \\
\hline $\begin{array}{l}\text { Qualification } \\
\text { Testing }\end{array}$ & $\begin{array}{l}\text { Software } \\
\text { Configuration Audit }\end{array}$ & $\begin{array}{l}\text { Activities } \\
\text { Software configuration audits in support of } \\
\text { the first release of Version } 8 \text { are: } \\
\text { Beta testing (May } 2007 \text { through } \\
\text { February 2010) } \\
\text { NRC peer review (April 2009 - open) } \\
\text { NRC Project Manager audit (Once per } \\
\text { year.) } \\
\text { Independent Verification and Validation } \\
\text { (April 2009 through March 2010) } \\
\text { Acceptance Test Plan testing (January } \\
\text { 2010 through March 2010) } \\
\text { Those activities which may continue } \\
\text { beyond the first release for further code } \\
\text { development and later software releases } \\
\text { may include beta testing, NRC peer } \\
\text { review, NRC Project Manager audit, and } \\
\text { Acceptance Test Plan testing. }\end{array}$ & $\begin{array}{l}\text { The SAPHIRE development team } \\
\text { may perform internal software } \\
\text { configuration audits scheduled as } \\
\text { necessary in support of } \\
\text { completing the software } \\
\text { requirements specification in } \\
\text { SAPHIRE. }\end{array}$ \\
\hline $\begin{array}{l}\text { Installation and } \\
\text { Acceptance }\end{array}$ & $\begin{array}{l}\text { Software } \\
\text { Configuration Audit } \\
\text { Post Mortem Review }\end{array}$ & $\begin{array}{l}\text { Independent Verification and Validation } \\
\text { (April } 2009 \text { through March 2010) } \\
\text { A Post-Mortem review may not be } \\
\text { necessary since the lessons learned } \\
\text { through the independent verification and } \\
\text { validation (IV\&V) reviews serve a similar } \\
\text { purpose in helping to develop software in } \\
\text { the future. The insights from the IV\&V } \\
\text { should be considered and follow-up } \\
\text { actions scheduled as appropriate. }\end{array}$ & $\begin{array}{l}\text { The SAPHIRE team tests the } \\
\text { installation of the software prior } \\
\text { to releasing beta or final } \\
\text { versions. Schedules for betas and } \\
\text { final versions of the software are } \\
\text { found in the Form } 189 \mathrm{~s} \text {. }\end{array}$ \\
\hline $\begin{array}{l}\text { Operations and } \\
\text { Sustaining } \\
\text { Engineering }\end{array}$ & $\begin{array}{l}\text { The formal reviews } \\
\text { and audits above, as } \\
\text { applicable }\end{array}$ & $\begin{array}{l}\text { Training on Version } 8 \text { to be scheduled. } \\
\text { Final NUREG/CR update for Version } 8 \text { to } \\
\text { be provided to NRC October } \mathbf{2 0 1 0 .}\end{array}$ & $\begin{array}{l}\text { SDP interface training classes } \\
\text { were held in } 2009 \text { in } 3 \text { Regions. } \\
\text { Update SDP interface training } \\
\text { manual as necessary. }\end{array}$ \\
\hline
\end{tabular}




\begin{tabular}{|l|ll|}
\hline Idaho National Laboratory & Page: 21 of 74 \\
\hline SOFTWARE PROJECT PLAN & Identifier: & INL/EXT-09-15853 \\
for SAPHIRE Version 8 N6423 & Revision: & 4 \\
& Effective Date: & $3 / 3 / 2010$ \\
\hline
\end{tabular}

Reviews that have been completed include:

- Preliminary design review by INL on SDP interface - November 16, 2004

- Preliminary design review by INL human factors department - February 15, 2005

- Preliminary design review by INL - July 15, 2005

- Preliminary design review by INL - April 25, 2006

- Preliminary design review by the NRC on SAPHIRE 8 - August 9, 2007

- Preliminary design review by the NRC on the SDP module - April 23, 2008

- Design review by the NRC as part of audit - December 3, 2008

- Design review by INL - April 24, 2008

\subsection{Quality Assessment (QA) and Improvement Approach}

Each JCN will have a quality level determination made by a Quality Level Analyst in accordance with LWP-13014 and documented on INL Form 414.A89. The quality level of each JCN currently active in Department C210 is Quality Level 3. Specific quality assurance requirements and activities will be delineated on the NRC Form 189 for each JCN.

Product quality is a key component of SAPHIRE. The SAPHIRE QA processes documented in the report provides the basis for setting quality objectives, progress, and the necessary framework for quality improvements. The QA plan will evolve as the SAPHIRE product is enhanced to provide the end user with solutions to their technical problems and cost-effectively meet user expectations. A majority of the changes within the SAPHIRE software occur because the end user has identified characteristics that provide "new potential", thus resulting in SAPHIRE evolving as each new feature is discovered and implemented. Therefore, the majority of software maintenance comes about not because of deficiencies in the code, but because it was modified to embrace improved methods for risk and reliability assessment.

In order to ensure the quality of the SAPHIRE software, the INL uses a variety of software development methods, including:

- Controlling software versions for both the formally released SAPHIRE versions, as well as for source code.

- Following a standard approach to bug fixes and new features.

- Using a cyclical design process to prototype changes.

- Performing acceptance tests that the software must pass prior to official release.

The source code version control library requires that individual programmers "check-out" all files that they intend to modify. Prior to "check-in", programmers must document any changes 


\begin{tabular}{|l|ll|}
\hline Idaho National Laboratory & Page: 22 of 74 \\
\hline SOFTWARE PROJECT PLAN & Identifier: & INL/EXT-09-15853 \\
for SAPHIRE Version 8 N6423 & Revision: & 4 \\
& Effective Date: & $3 / 3 / 2010$ \\
\hline
\end{tabular}

made. A record is kept of all changes, both as explained by the developer, and as individual copies of each version of a file. At any time, the developer can retrieve past versions intact, if necessary. Since the SAPHIRE software program is continually modified, the version control procedure ensures a methodical approach to tracking and releasing these changes.

As new features and bug fixes are made, the INL developers follow a standard approach to integrating these items into SAPHIRE. For bug fixes, the developers take notes from the user describing the general context of the bug, as well as step-by-step actions to reproduce the bugs. This bug information includes acquiring a copy of the user's database, when necessary. Then, the bug is classified and prioritized according to severity. A bug is considered "minor" if it inconveniences the user, but a workaround exists to produce a correct answer. A bug is "major" if it prevents the user from obtaining the correct answer. Software enhancements follow much the same approach as bug fixes. Enhancements are prioritized and implemented, with intermediate testing by the developer and often by the requestor. Bugs and improvements, and their status, are tracked on the SAPHIRE website. Once the process and results appear acceptable, the feature is added to the next official release.

The level of effort for the software design process corresponds to the size and complexity of the proposed change. Developers use a cyclical prototyping design methodology as a means to clarify and refine the change. The prototyping process involves the requestor throughout development. The developers will interact with the requestor(s) both initially and throughout the design and development process to ensure the change accomplishes the expected goal.

Prior to any official SAPHIRE release of versions 8, the software is run through the tests in the Acceptance Test Plan. The tests simulate user input to the computer through a test script, and results are captured and compared to expected results. This ensures that given a static input PRA file, the risk or reliability results from SAPHIRE will be consistent from one release to the next. These acceptance tests were developed by first identifying the critical tasks performed in a PRA. Then these tasks were mapped to the SAPHIRE functions that perform these tasks. The critical functions were determined to include the following:

1. Fault tree analysis

2. Event tree and sequence analysis

3. End state analysis

4. Importance measures analysis

5. Uncertainty analysis

6. Change sets

7. Data utility functions

8. Workspace module functionality

The SAPHIRE QA process encompasses several activities the INL uses to ensure quality throughout the development cycle. These activities are illustrated in Figure 2. 


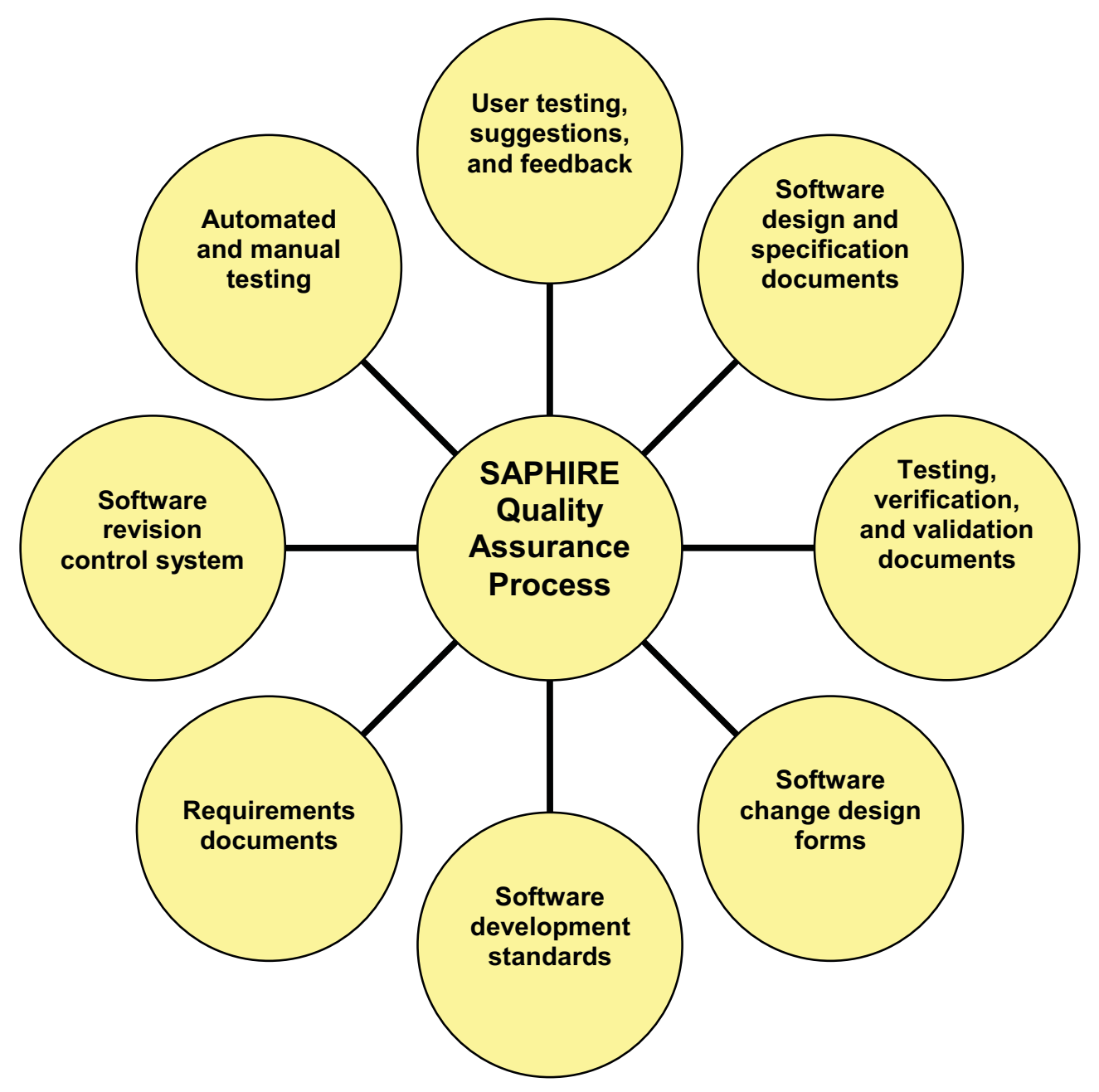

Figure 2. SAPHIRE quality assurance process.

As part of the overall QA process, the SAPHIRE Testing Verification and Validation (TV\&V) process and results were previously documented in NUREG/CR-6688, "Testing, Verifying, and Validating SAPHIRE Versions 6.0 and 7.0 (Smith et al, 2000). Within that document, Section 1 explains that the version 6 and 7 TV\&V departs from earlier V\&V efforts (for versions 4 and 5) by focusing on the development and execution of a set of automated test scripts. This TV\&V process was expanded and automated so that the validity of the core functionality of SAPHIRE can be verified on an ongoing basis with each incremental release. For the first release of SAPHIRE 8, an independent verification and validation is being performed ("SAPHIRE 8 Software Independent Verification and Validation Plan Document ID: INL/EXT-09-15649”). 


\begin{tabular}{|c|c|c|}
\hline Idaho National Laboratory & & Page: 24 of 74 \\
\hline \multirow{3}{*}{$\begin{array}{l}\text { SOFTWARE PROJECT PLAN } \\
\text { for SAPHIRE Version } 8 \text { N6423 }\end{array}$} & Identifier: & INL/EXT-09-15853 \\
\hline & Revision: & 4 \\
\hline & Effective Date: & $3 / 3 / 2010$ \\
\hline
\end{tabular}

The QA process for Version 8 builds upon this TV\&V approach and is planned to be documented in a future SAPHIRE NUREG/CR update.

\subsection{Use of Project Metrics}

Metrics are an integral part of tracking quality of the software development process and products. While numerous possible metrics exist, the SAPHIRE project will focus on using the metrics of:

- $\quad$ Earned Value to track cost and schedule variances. This metric as measured by variances will be reported monthly to the NRC.

- $\quad$ Trending of calculational errors as reported in the Change Request tracking system.

Other metrics derived from source code, such as McCabe's complexity measure, may be considered for future use.

\subsection{Deliverables}

Software releases are managed via the SAPHIRE Release Management process for software stored in the RCS. Currently, this process looks like that shown in Figure 3:

Key milestones for the SAPHIRE development project are tracked and reported in the monthly status report sent to the NRC. 


\section{SAPHIRE Release Management}

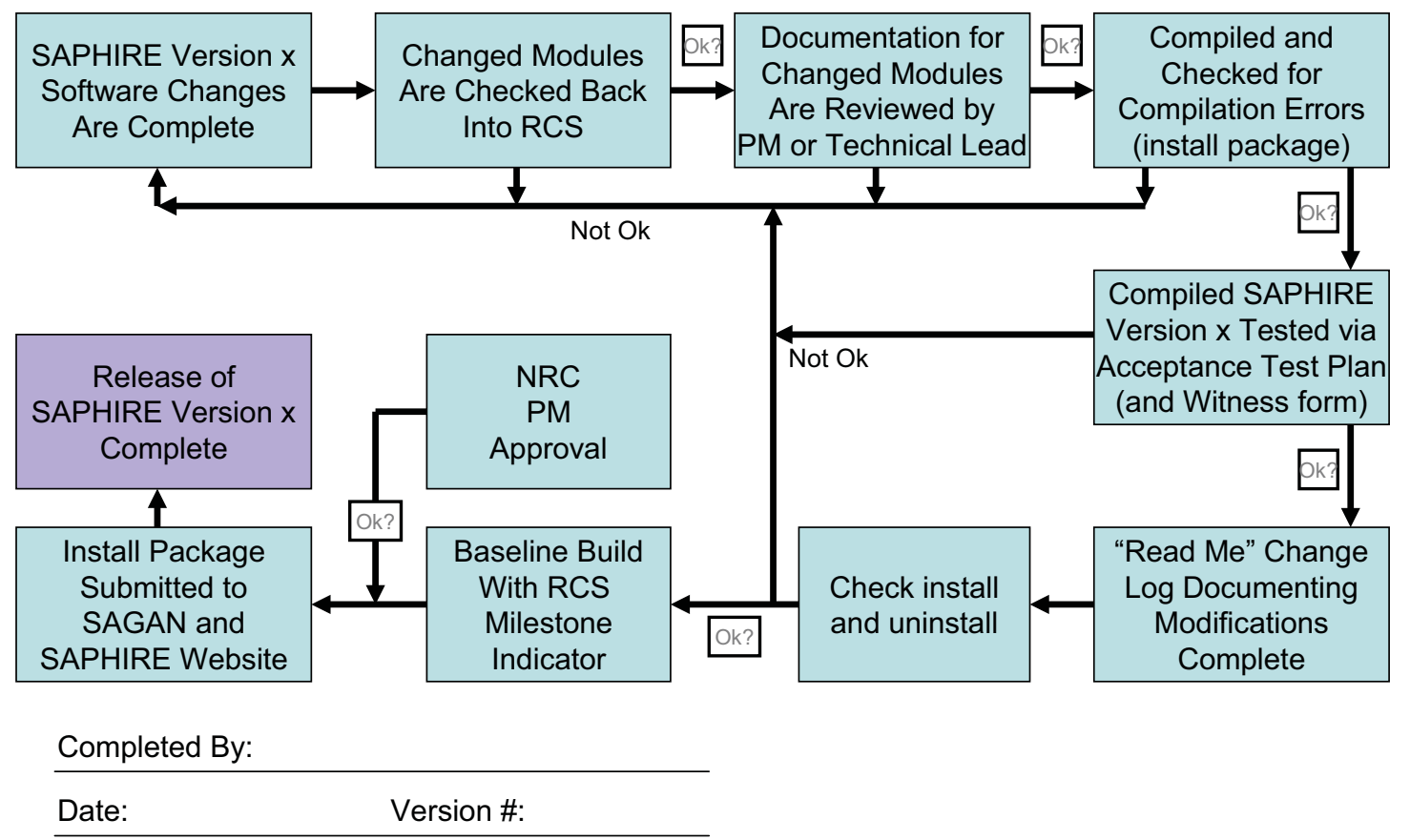

Figure 3. SAPHIRE 8 Release Management Process.

Project closure will be accomplished in accordance with NRC Directive 11.7. When all project work has been accomplished, then NRC will either add new work scope and extend the project or request information to initiate closeout procedures. The INL will provide the required information in a closeout letter to the DOE-ID Project Manager. Attached to the letter will be an NRC Property Certification form, showing the disposition of any NRC-purchased property, and INL Form 481.24, WFO Closeout Verification Sheet, showing any unexpended funds available for de-obligation. The DOE-ID Project Manager will forward the information to the appropriate NRC Office.

The NRC will send a final NRC Form 173 with final closeout instructions. Acceptance of the final NRC Form 173 by the DOE-ID Project Manager closes out the project. Funds will be deobligated from the DOE account and returned to the NRC as part of the processing of the signed NRC Form 173. 


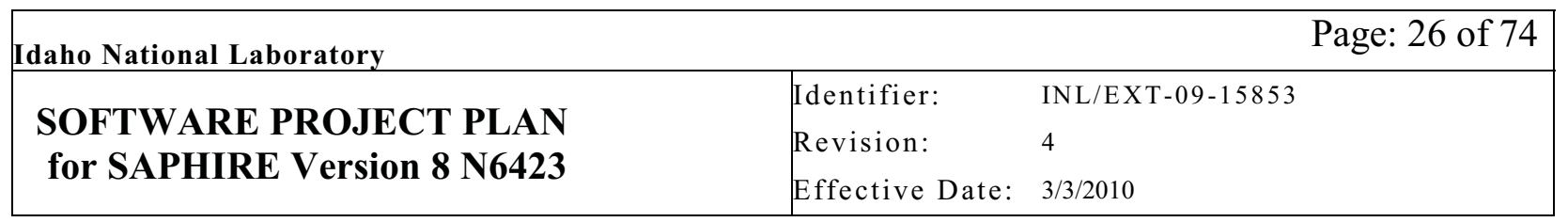

\section{Appendix A}

\section{SAPHIRE 8 Work Development Plan}




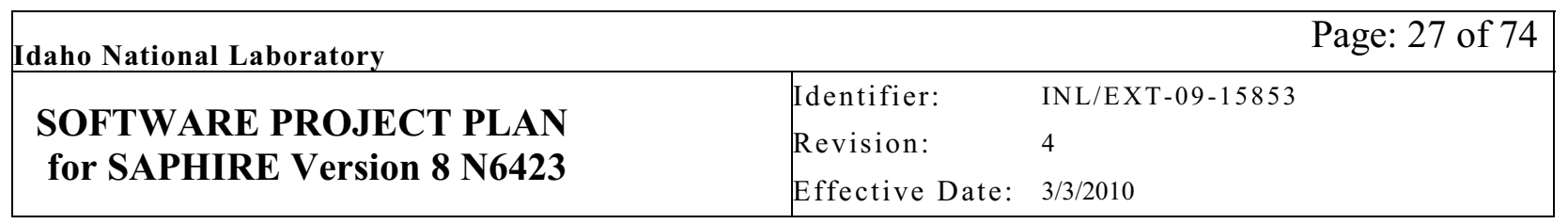

\section{SAPHIRE VERSION 8}

Work Development Plan

August 2007 


\begin{tabular}{|l|ll|}
\hline Idaho National Laboratory & Page: 28 of 74 \\
\hline SOFTWARE PROJECT PLAN & Identifier: & INL/EXT-09-15853 \\
for SAPHIRE Version 8 N6423 & Revision: & 4 \\
& Effective Date: & $3 / 3 / 2010$ \\
\hline
\end{tabular}

\section{Overview of SAPHIRE 8}

SAPHIRE Version 8 is being developed by the Idaho National Laboratory (INL) to meet the needs of users at the Nuclear Regulatory Commission (NRC). Its development improves upon the features and capabilities of SAPHIRE Version 7. The code will accommodate larger, more complex models. Also, user interfaces with the code are being tailored to specific program requirements.

The code considers the needs of the Standardized Plant Analysis Risk (SPAR) models. SAPHIRE Version 7 had a number of improvements made to accommodate the SPAR models specific needs. Such features and capabilities will be retained, and further improvements will be made. The SAPHIRE Version 8 development plan shows the work currently identified to be completed. The internal events SPAR models will be improved to run in the user interface for the Significance Determination Process. User comments on the integration capabilities for the internal and external events models will be addressed. The Large Early Release Frequency (LERF) analysis design will be completed to run the new LERF SPAR models being developed. No work has been specified for the low power and shutdown models.

To support the development of "integrated models" (models with multiple model types), features such as an "accident sequence matrix" are used to enable the development of external events models via a semi-automated process. In SAPHIRE 7, different "types" of models were stored in select analysis type parts of the database such that aggregate results were not available. In SAPHIRE 8, the user may define up to 32 "model types" (e.g., full power internal events, low power internal events, seismic events, and flooding events) such that this information is shareable within a single project, enabling aggregate (or single if needed) risk assessment. Also, the fault tree model editor has been designed for the different model types and shows the user which events (and their respective probabilities) apply to the individual model types.

Interfaces are input and output (I/O) designs with the SAPHIRE code to meet the needs of users. In addition to the SAPHIRE interface, which is used mainly by advanced risk analysts, a simplified user interface called the Graphical Evaluation Module (GEM) has been developed for performing events analyses. In the new SAPHIRE version, the GEM interface is being modified to meet user needs. The objective of the task is to develop a user-friendly I/O interface for use with the Level 1, Revision 3 SPAR models when performing Significance Determination Process Phase 2 analyses and analyses in the Accident Sequence Precursor program. Work will continue to address comments through general release of SAPHIRE Version 8.

The speed of the calculations in SAPHIRE Version 8 will need to be improved to handle larger, more complex models. The code has been tested on a multi-processor computer as a proof-ofconcept study. Work related to increasing computational speed is included in the plan.

SAPHIRE Version 8 quality assurance will be more formal than that for Version 7 . It will utilize a formal software verification and validation plan, and other quality assurance improvements over the Version 7 practices will be made. 


\begin{tabular}{|c|c|c|}
\hline Idaho National Laboratory & & Page: 29 of 74 \\
\hline \multirow{3}{*}{$\begin{array}{l}\text { SOFTWARE PROJECT PLAN } \\
\text { for SAPHIRE Version } 8 \text { N6423 }\end{array}$} & Identifier: & INL/EXT-09-15853 \\
\hline & Revision: & 4 \\
\hline & Effective Date: & $3 / 3 / 2010$ \\
\hline
\end{tabular}

\section{SAPHIRE Version 8 Development Background}

Work began under JCN Y6394, "Maintenance and User Support for SAPHIRE Code and Library of PRAs." Development continued under JCN N6203, "Maintain and Support SAPHIRE Code and Library," up through Revision 2. Work is now continuing under JCN N6423, "SAPHIRE Version 8." 


\begin{tabular}{|c|c|c|}
\hline Idaho National Laboratory & & Page: 30 of 74 \\
\hline \multirow{3}{*}{$\begin{array}{l}\text { SOFTWARE PROJECT PLAN } \\
\text { for SAPHIRE Version } 8 \text { N6423 }\end{array}$} & Identifier: & INL/EXT-09-15853 \\
\hline & Revision: & 4 \\
\hline & Effective Date: & $3 / 3 / 2010$ \\
\hline
\end{tabular}

\section{DETAILED TASK/SUBTASK BREAKDOWN}

This document, the SAPHIRE 8 Work Development Plan (WDP), provides an outline of the effort required to complete a beta and release version of SAPHIRE 8. The WDP includes information related to technical activities for the tasks and subtasks to finish the beta and general-released version of SAPHIRE 8. Specified in these task descriptions are how they support the development of SAPHIRE pertaining to six key areas:

1. Support for SPAR Models

2. Support for SAPHIRE/GEM User Interfaces

3. Features and Capabilities

4. Quality Assurance

5. Documentation

6. Additional work to be considered

The current schedule for SAPHIRE 8 (shown below) includes a finished first beta release in January, 2008. An NRC peer review of the beta is to be completed by October, 2008. As part of the development process, the NRC will schedule an Advisory Committee on Reactor Safeguards (ACRS) briefing on SAPHIRE 8 in 2008. 


\begin{tabular}{|l|ll|}
\hline Idaho National Laboratory & \multicolumn{2}{|c|}{ Page: 31 of 74 } \\
\hline SOFTWARE PROJECT PLAN & Identifier: & INL/EXT-09-15853 \\
for SAPHIRE Version 8 N6423 & Revision: & 4 \\
& Effective Date: & $3 / 3 / 2010$ \\
\hline
\end{tabular}

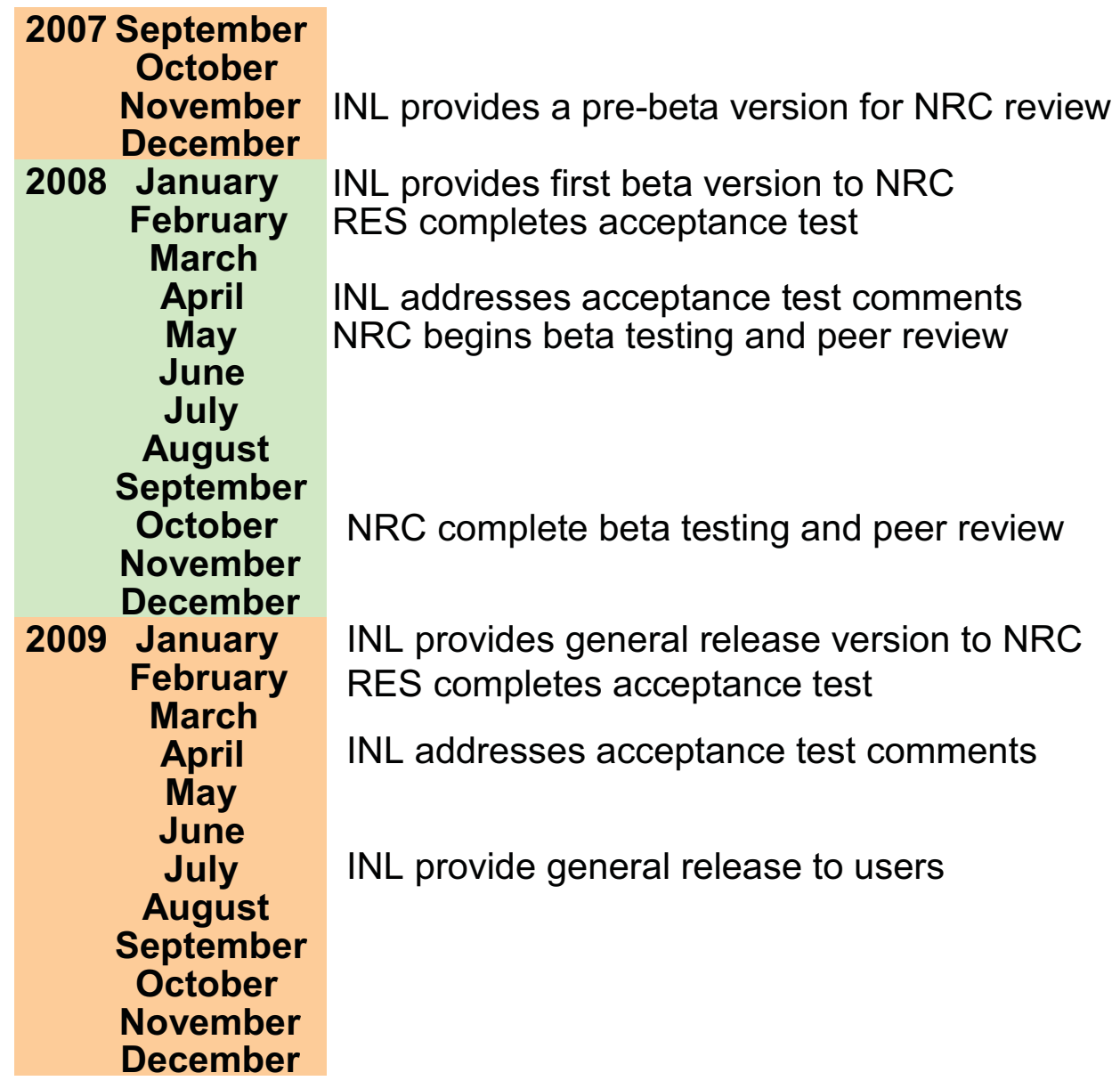

Prior to the NRC peer review, a second beta version will be finished (May 2008) and subsequent training on the software will be offered to the beta testers and reviewers. It is expected that this training will be held at NRC $\mathrm{HQ}$.

In addition to the task-level information, an estimate of the level of effort for each task is provided. These levels of efforts have been aggregated for the fiscal years 2007 through 2009 and are shown below:

\section{Estimated Level of Effort}

FY07: 21.0 staff-months (JCN 6423, Rev. 0, "SAPHIRE Version 8")

FY08: 24.5 staff-months

FY09: 24.5 staff-months 


\section{HIGH-LEVEL TASKS}

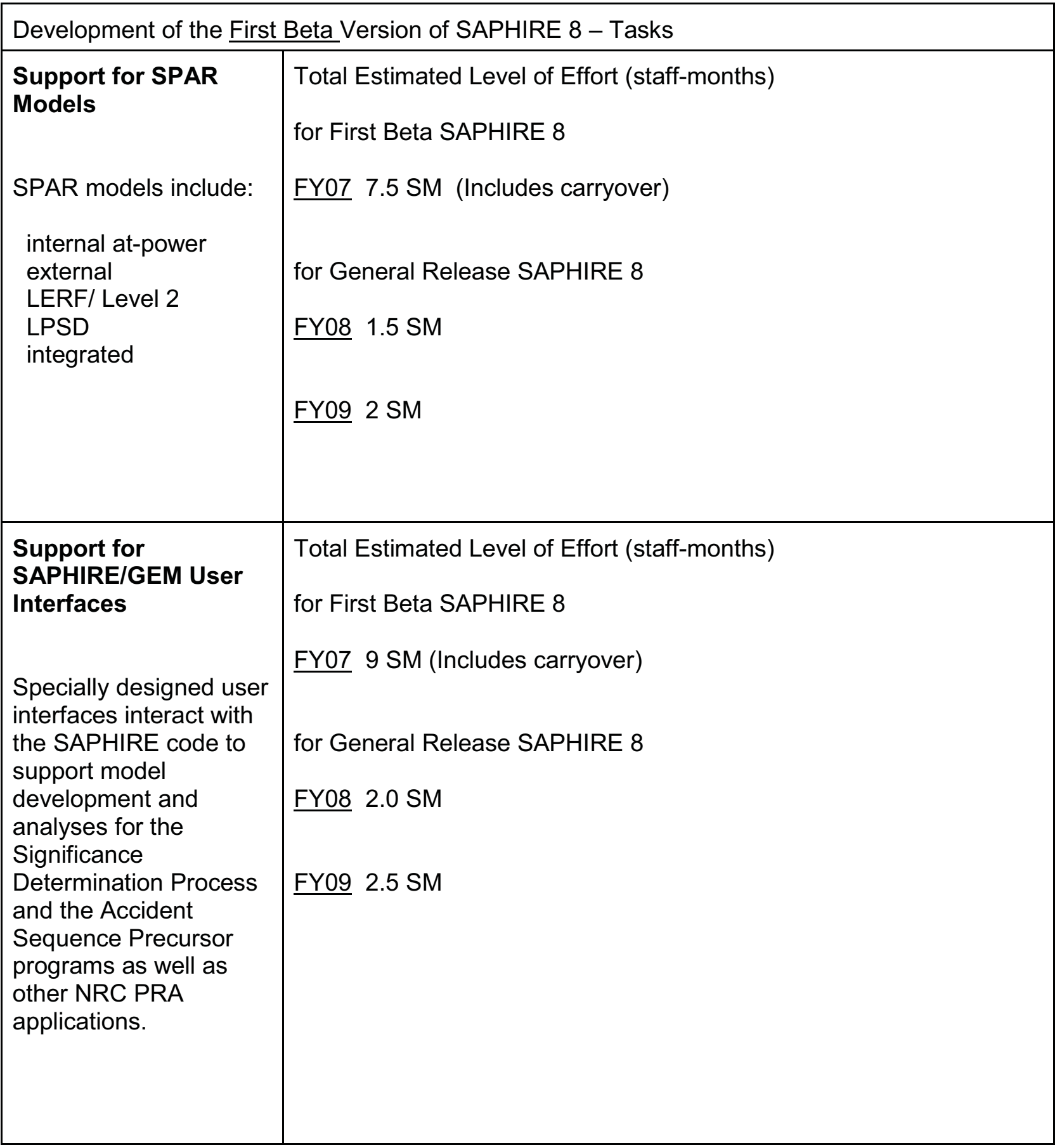


SOFTWARE PROJECT PLAN for SAPHIRE Version 8 N6423

$\begin{array}{ll}\text { Identifier: } & \text { INL/EXT-09-15853 } \\ \text { Revision: } & 4 \\ \text { Effective Date: } & 3 / 3 / 2010\end{array}$

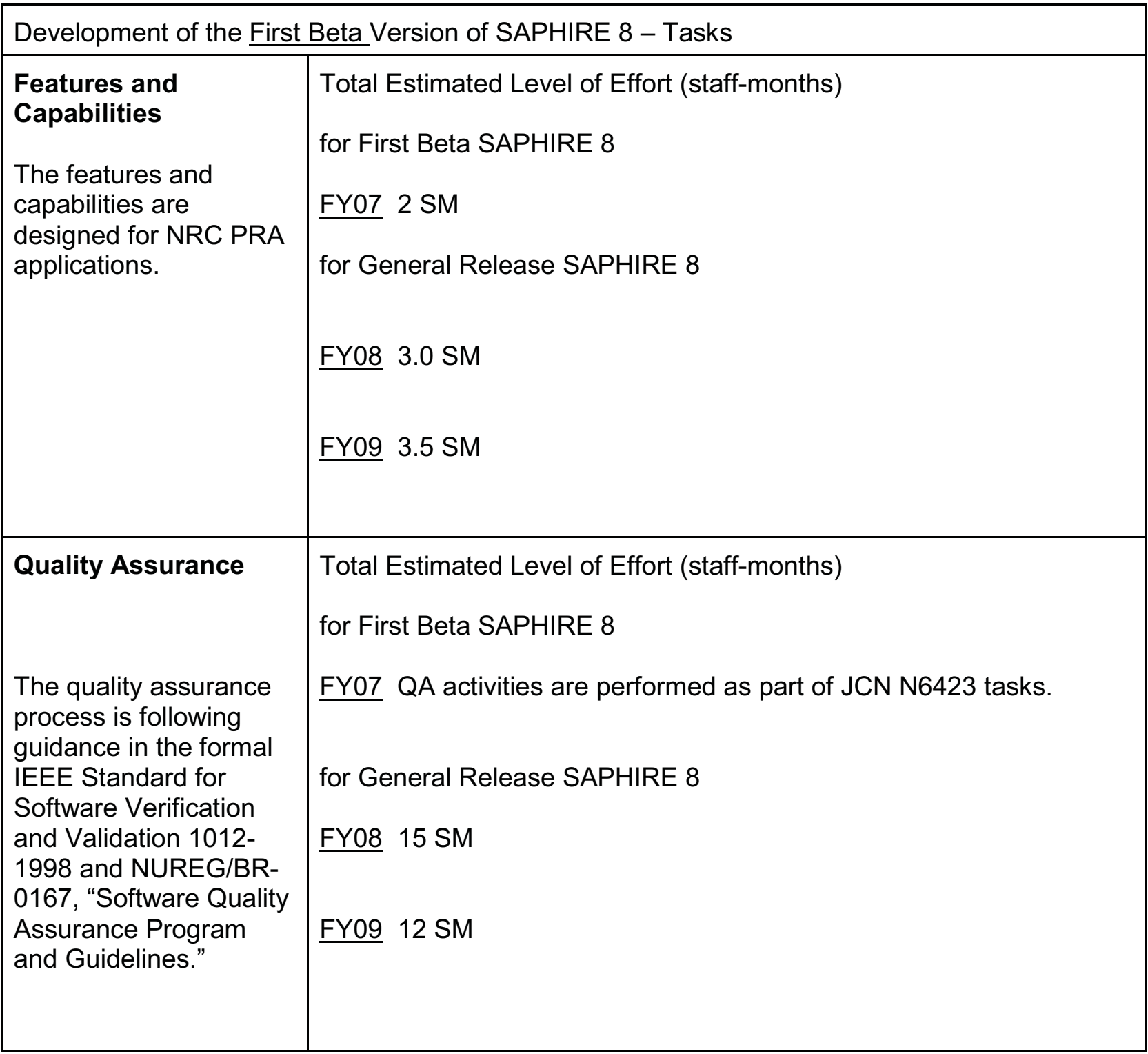


SOFTWARE PROJECT PLAN for SAPHIRE Version 8 N6423

$\begin{array}{ll}\text { Identifier: } & \text { INL/EXT-09-15853 } \\ \text { Revision: } & 4 \\ \text { Effective Date: } & 3 / 3 / 2010\end{array}$

\begin{tabular}{|c|c|}
\hline \multicolumn{2}{|c|}{ Development of the First Beta Version of SAPHIRE 8 - Tasks } \\
\hline $\begin{array}{l}\text { Documentation } \\
\text { Documentation covers } \\
\text { development of a user } \\
\text { manual, help } \\
\text { documentation, and an } \\
\text { updated NUREG/CR. }\end{array}$ & $\begin{array}{l}\text { Total Estimated Level of Effort (staff-months) } \\
\text { for First Beta SAPHIRE } 8 \\
\underline{\text { FY07 } 1} \\
\text { for General Release SAPHIRE } 8 \\
\underline{\text { FY08 } 3.0} \\
\text { FY09 } 4.5\end{array}$ \\
\hline
\end{tabular}

Note: Estimated completion dates are given in the subtask tables. 


\section{SUBTASKS}

\begin{tabular}{|c|c|c|c|c|c|}
\hline \multicolumn{6}{|c|}{ Support for SPAR Models - Subtasks } \\
\hline \multirow[t]{8}{*}{$\begin{array}{l}\text { Internal events at- } \\
\text { power }\end{array}$} & \multicolumn{5}{|c|}{$\begin{array}{l}\text { Estimated Level of Effort for First Beta SAPHIRE } 8 \\
\underline{\text { FY07 } 2.5 \mathrm{SM} \text { (Includes carryover) }}\end{array}$} \\
\hline & Subtask & Status/Milestones & $\begin{array}{l}\text { Staff- } \\
\text { months }\end{array}$ & \multicolumn{2}{|c|}{ Votes } \\
\hline & IE-B-1 & \multirow{2}{*}{$\begin{array}{l}\text { November 30, } \\
2007\end{array}$} & \multirow{2}{*}{$\frac{\mathrm{FY} 07}{2.5}$} & \multirow{2}{*}{\multicolumn{2}{|c|}{$\begin{array}{l}\text { SPAR models made to } \\
\text { run in the SDP } \\
\text { interface by adding } \\
\text { necessary information. } \\
\text { This is Task } 3 \text { in } \\
\text { N6423. }\end{array}$}} \\
\hline & $\begin{array}{l}\text { Populate for } \\
\text { use with SDP } \\
\text { interface }\end{array}$ & & & & \\
\hline & \multicolumn{5}{|c|}{$\begin{array}{l}\text { Estimated Level of Effort General Release SAPHIRE } 8 \\
\text { FY08 } 0.5 \quad \underline{\text { FY09 }} 0.5\end{array}$} \\
\hline & Subtask & Status/Milestones & $\begin{array}{l}\text { Staff- } \\
\text { months }\end{array}$ & \multicolumn{2}{|c|}{ Notes } \\
\hline & IE-GR-1 & \multirow{2}{*}{$\begin{array}{l}\text { Through general } \\
\text { release of } \\
\text { SAPHIRE Version } \\
8 .\end{array}$} & \multirow{2}{*}{$\begin{array}{l}\frac{F Y 08}{0.5} \\
\frac{F Y 09}{0.5}\end{array}$} & \multirow{2}{*}{\multicolumn{2}{|c|}{$\begin{array}{l}\text { This addresses future } \\
\text { co-ordination between } \\
\text { SPAR model and SDP } \\
\text { interface updates. }\end{array}$}} \\
\hline & $\begin{array}{l}\text { Coordinate } \\
\text { SPAR model } \\
\text { and SDP } \\
\text { updates. }\end{array}$ & & & & \\
\hline \multirow[t]{2}{*}{ External Events } & \multicolumn{5}{|c|}{$\begin{array}{l}\text { Estimated Level of Effort for First Beta SAPHIRE } 8 \\
\underline{\text { FY07 } 0}\end{array}$} \\
\hline & Subtask & Status/Milestones & Staff-m & aths & Notes \\
\hline
\end{tabular}


SOFTWARE PROJECT PLAN for SAPHIRE Version 8 N6423

$\begin{array}{ll}\text { Identifier: } & \text { INL/EXT-09-15853 } \\ \text { Revision: } & 4 \\ \text { Effective Date: } & 3 / 3 / 2010\end{array}$

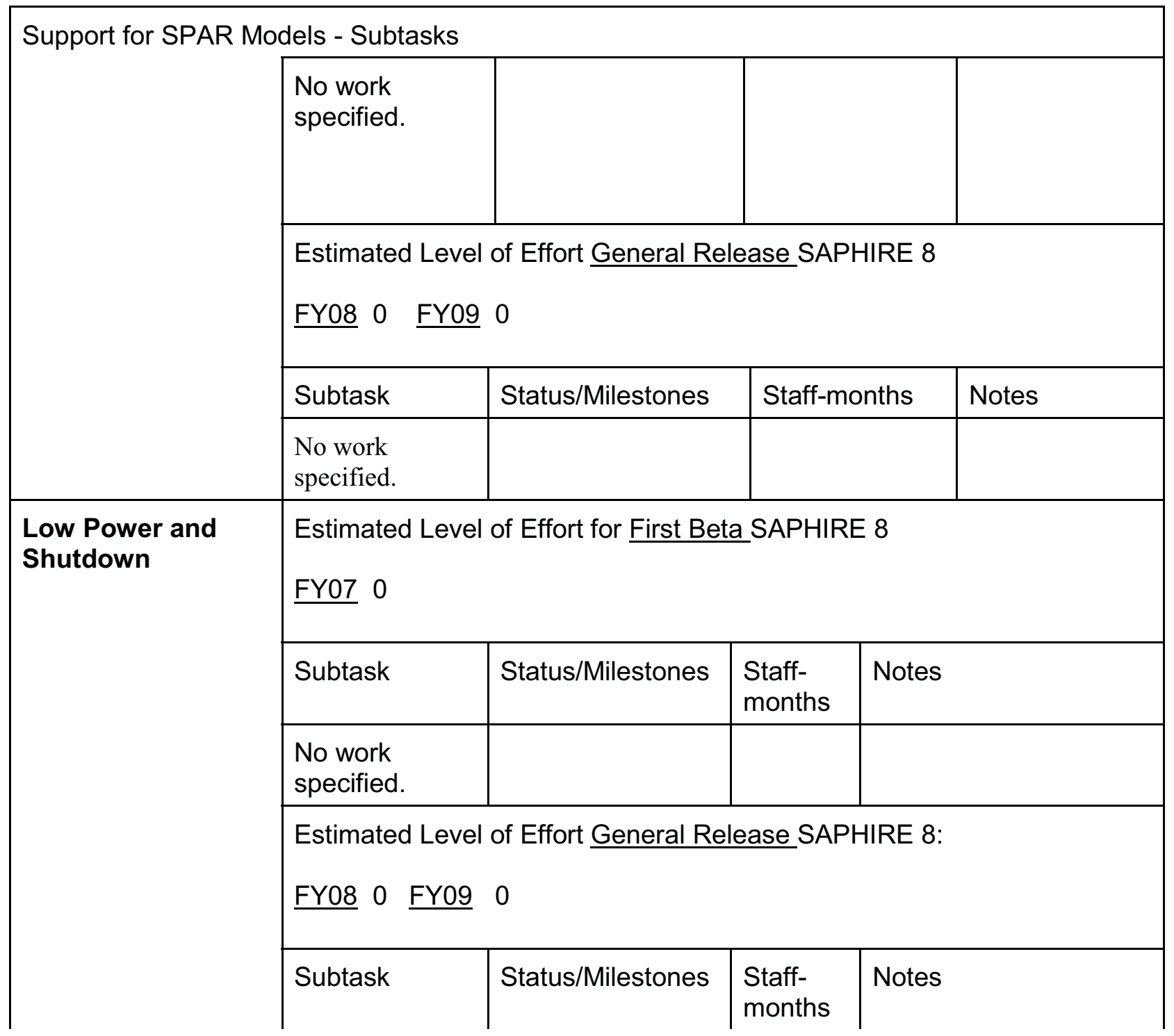


SOFTWARE PROJECT PLAN for SAPHIRE Version 8 N6423

Identifier: INL/EXT-09-15853

Revision: $\quad 4$

Effective Date: 3/3/2010

\begin{tabular}{|c|c|c|c|c|}
\hline \multicolumn{5}{|c|}{ Support for SPAR Models - Subtasks } \\
\hline & $\begin{array}{l}\text { No work } \\
\text { specified. }\end{array}$ & & & \\
\hline \multirow[t]{5}{*}{ LERF/Level 2} & \multicolumn{4}{|c|}{$\begin{array}{l}\text { Estimated Level of Effort for First Beta SAPHIRE 8: } \\
\text { FY07 } 5 \text { SM (Includes carryover) }\end{array}$} \\
\hline & Subtask & \multirow[t]{2}{*}{ Status/Milestones } & \multirow{2}{*}{$\begin{array}{l}\text { Staff- } \\
\text { months }\end{array}$} & \multirow[t]{2}{*}{ Notes } \\
\hline & LE-B-1 & & & \\
\hline & 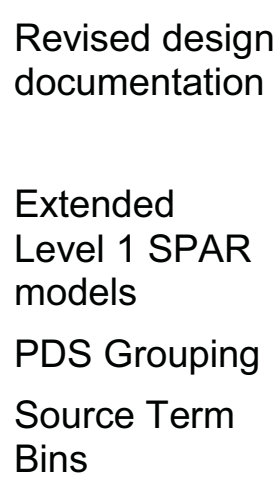 & $\begin{array}{l}1 \text { month after } \\
\text { work plan } \\
\text { acceptance } \\
\text { January } 2008\end{array}$ & $\begin{array}{l}\frac{\text { FY07 }}{\text { Included }} \\
\text { in Task } \\
4 \text { of } \\
\text { N6423 }\end{array}$ & \\
\hline & \multicolumn{4}{|c|}{ 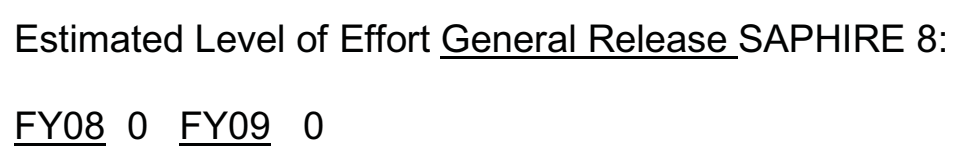 } \\
\hline
\end{tabular}


SOFTWARE PROJECT PLAN for SAPHIRE Version 8 N6423

Identifier: INL/EXT-09-15853

Revision: $\quad 4$

Effective Date: $3 / 3 / 2010$

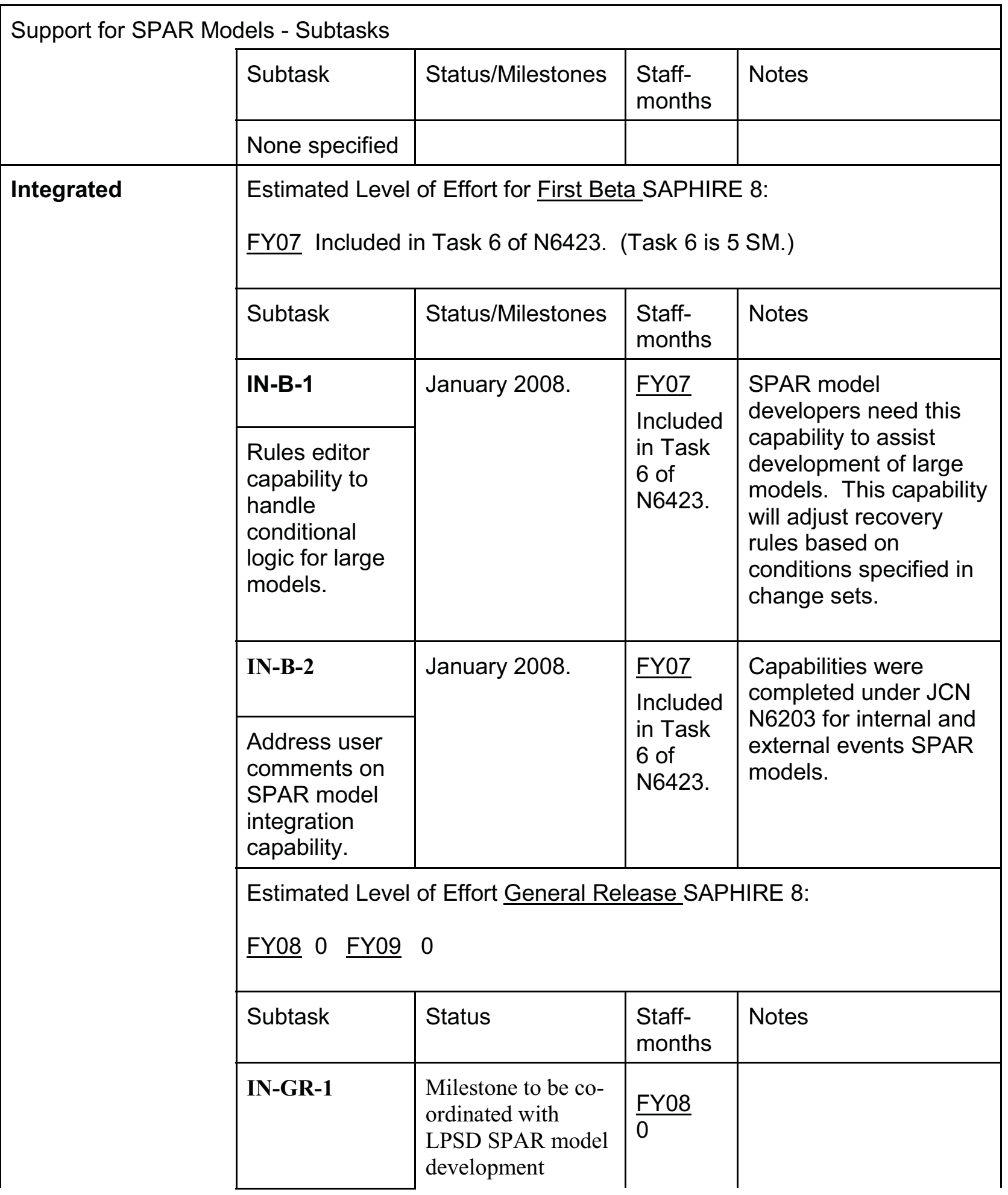




\section{SOFTWARE PROJECT PLAN} for SAPHIRE Version 8 N6423

$\begin{array}{ll}\text { Identifier: } & \text { INL/EXT-09-15853 } \\ \text { Revision: } & 4 \\ \text { Effective Date: } & 3 / 3 / 2010\end{array}$

\begin{tabular}{|c|c|c|c|c|}
\hline \multicolumn{2}{|c|}{ Support for SPAR Models - Subtasks } & & \multirow[b]{2}{*}{$\frac{\text { FY09 }}{0}$} & \\
\hline & $\begin{array}{l}\text { Include LPSD in } \\
\text { integrated } \\
\text { model. }\end{array}$ & & & \\
\hline \multirow[t]{4}{*}{$\begin{array}{l}\text { Address Beta Test } \\
\text { Comments - SPAR } \\
\text { Model Support }\end{array}$} & \multicolumn{4}{|c|}{$\begin{array}{l}\text { Estimated Level of Effort General Release SAPHIRE 8: } \\
\underline{\text { FY08 }} 1.0 \underline{\text { FY09 }} 1.5\end{array}$} \\
\hline & Subtask & Status & $\begin{array}{l}\text { Staff- } \\
\text { months }\end{array}$ & Notes \\
\hline & SM-GR-1 & \multirow{2}{*}{$\begin{array}{l}\text { Complete by } \\
\text { general release of } \\
\text { SAPHIRE Version } \\
8 .\end{array}$} & \multirow{2}{*}{$\begin{array}{l}\frac{F Y 08}{1.0} \\
\frac{F Y 09}{1.5}\end{array}$} & \\
\hline & $\begin{array}{l}\text { Address Beta } \\
\text { Test } \\
\text { Comments - } \\
\text { SPAR Model } \\
\text { Support }\end{array}$ & & & \\
\hline
\end{tabular}


SOFTWARE PROJECT PLAN for SAPHIRE Version 8 N6423

Identifier: INL/EXT-09-15853

Revision: $\quad 4$

Effective Date: $3 / 3 / 2010$

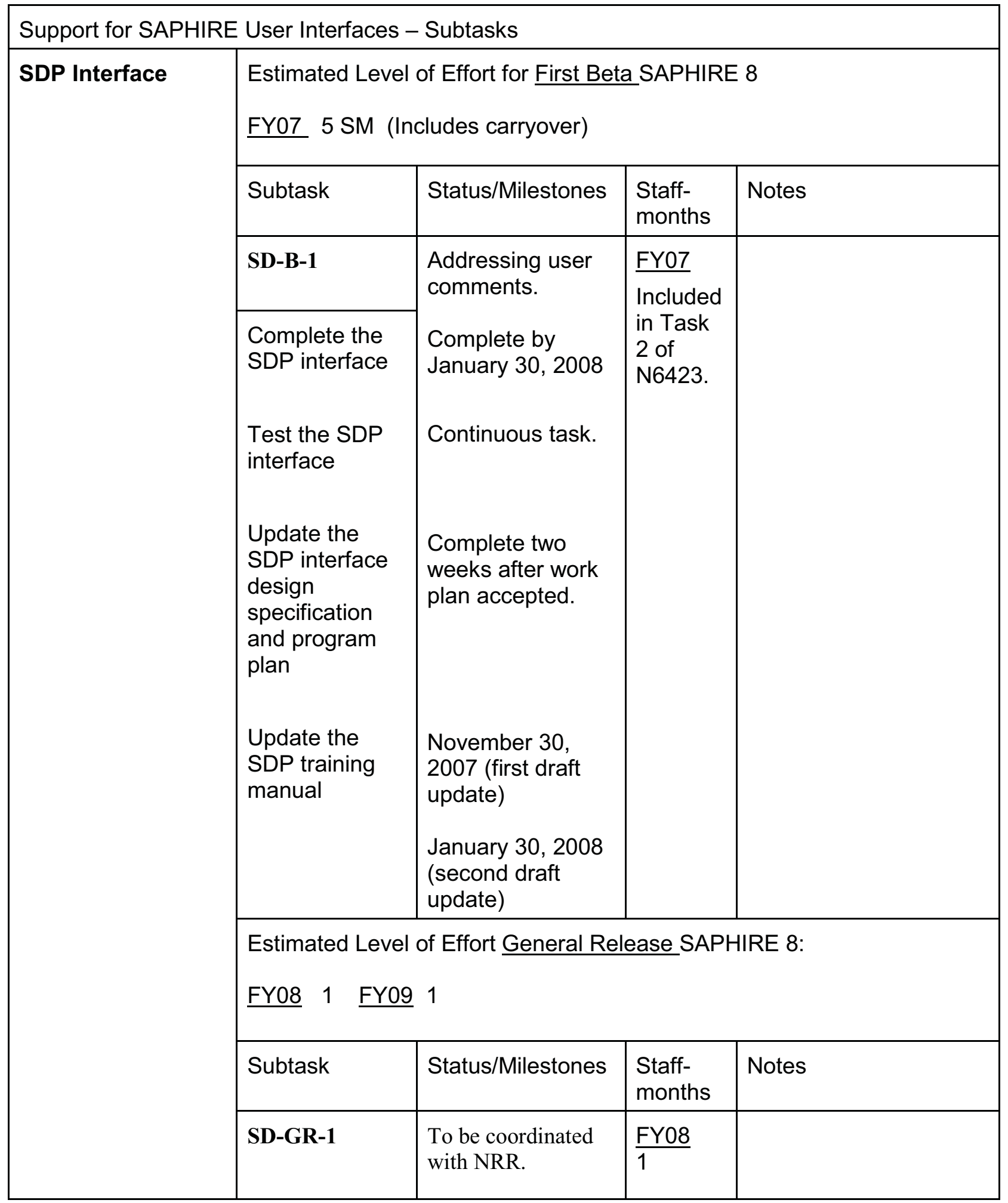


SOFTWARE PROJECT PLAN for SAPHIRE Version 8 N6423

$\begin{array}{ll}\text { Identifier: } & \text { INL/EXT-09-15853 } \\ \text { Revision: } & 4 \\ \text { Effective Date: } & 3 / 3 / 2010\end{array}$

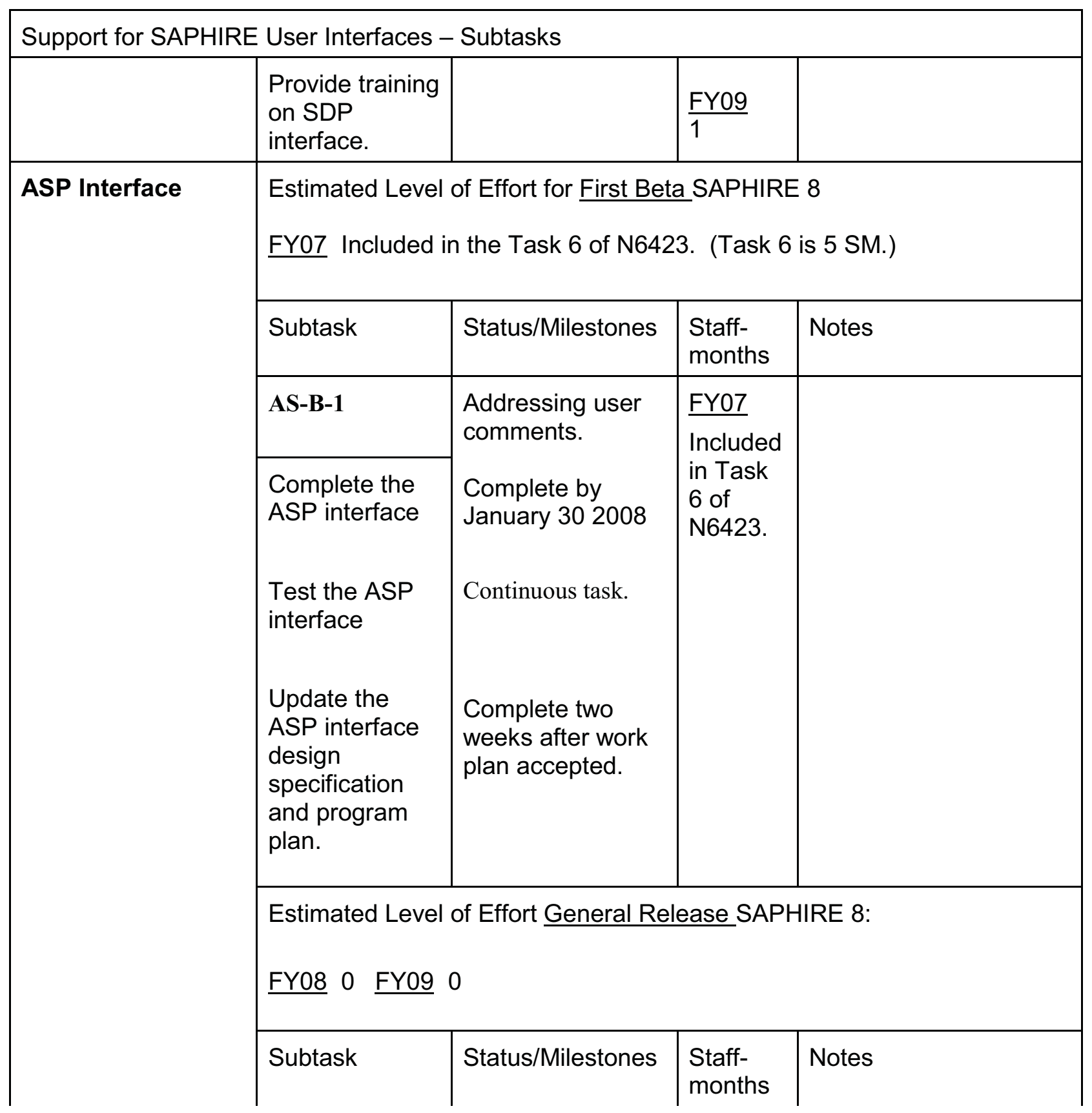


SOFTWARE PROJECT PLAN for SAPHIRE Version 8 N6423

Identifier: INL/EXT-09-15853

Revision: $\quad 4$

Effective Date: $3 / 3 / 2010$

\begin{tabular}{|c|c|c|c|c|}
\hline \multicolumn{5}{|c|}{ Support for SAPHIRE User Interfaces - Subtasks } \\
\hline & $\begin{array}{l}\text { No work } \\
\text { specified. }\end{array}$ & & & \\
\hline \multirow[t]{6}{*}{$\begin{array}{l}\text { General Analysis } \\
\text { Interface }\end{array}$} & \multicolumn{4}{|c|}{ 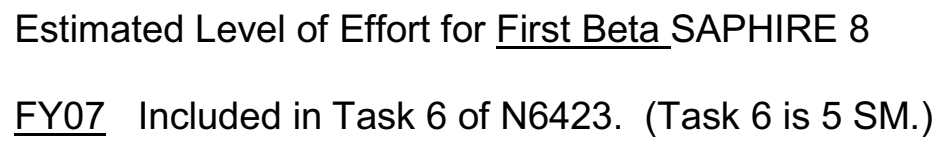 } \\
\hline & Subtask & Status/Milestones & $\begin{array}{l}\text { Staff- } \\
\text { months }\end{array}$ & Notes \\
\hline & GA-B-1 & $\begin{array}{l}\text { Addressing user } \\
\text { comments. }\end{array}$ & $\frac{\text { FY07 }}{\text { Included }}$ & \\
\hline & $\begin{array}{l}\text { Complete the } \\
\text { General } \\
\text { Analysis } \\
\text { interface }\end{array}$ & $\begin{array}{l}\text { Complete by } \\
\text { January } 302008\end{array}$ & $\begin{array}{l}\text { in Task } \\
6 \text { of } \\
\text { N6423. }\end{array}$ & \\
\hline & $\begin{array}{l}\text { Test the } \\
\text { General } \\
\text { Analysis } \\
\text { interface }\end{array}$ & Continuous task. & & \\
\hline & $\begin{array}{l}\text { Update the } \\
\text { General } \\
\text { Analysis } \\
\text { interface } \\
\text { design } \\
\text { specification } \\
\text { and program } \\
\text { plan }\end{array}$ & $\begin{array}{l}\text { Complete two } \\
\text { weeks after work } \\
\text { plan accepted. }\end{array}$ & & \\
\hline
\end{tabular}




\begin{tabular}{|l|}
\hline Idaho National Laboratory \\
\hline SOFTWARE PROJECT PLAN \\
for SAPHIRE Version 8 N6423
\end{tabular}

Page: 43 of 74

\section{for SAPHIRE Version 8 N6423}

$\begin{array}{ll}\text { Identifier: } & \text { INL/EXT-09-15853 } \\ \text { Revision: } & 4 \\ \text { Effective Date: } & 3 / 3 / 2010\end{array}$

\begin{tabular}{|c|c|c|c|c|}
\hline \multicolumn{5}{|c|}{ Support for SAPHIRE User Interfaces - Subtasks } \\
\hline & \multicolumn{4}{|c|}{$\begin{array}{l}\text { Estimated Level of Effort General Release SAPHIRE } 8 \\
\text { FY08 } 0 \text { FY09 } 0\end{array}$} \\
\hline & Subtask & Status/Milestones & $\begin{array}{l}\text { Staff- } \\
\text { months }\end{array}$ & Notes \\
\hline & $\begin{array}{l}\text { No work } \\
\text { specified. }\end{array}$ & & & \\
\hline \multirow[t]{7}{*}{ SAPHIRE interface } & \multicolumn{4}{|c|}{$\begin{array}{l}\text { Estimated Level of Effort for First Beta SAPHIRE 8: } \\
\text { FY07 Included in Task } 6 \text { of N6423. (Task } 6 \text { is } 5 \text { SM.) }\end{array}$} \\
\hline & Subtask & Status/Milestones & $\begin{array}{l}\text { Staff- } \\
\text { months }\end{array}$ & Notes \\
\hline & SA-B-1 & $\begin{array}{l}\text { Addressing user } \\
\text { comments. }\end{array}$ & $\frac{\text { FY07 }}{\text { Included }}$ & $\begin{array}{l}\text { Examples include the } \\
\text { project integration }\end{array}$ \\
\hline & $\begin{array}{l}\text { Complete the } \\
\text { SAPHIRE } \\
\text { interface }\end{array}$ & $\begin{array}{l}\text { Complete by } \\
\text { January } 302008\end{array}$ & $\begin{array}{l}\text { in Task } \\
6 \text { of } \\
\text { N6423. }\end{array}$ & $\begin{array}{l}\text { phase modeling } \\
\text { capability. }\end{array}$ \\
\hline & $\begin{array}{l}\text { Test the } \\
\text { SAPHIRE } \\
\text { interface }\end{array}$ & Continuous task. & & \\
\hline & $\begin{array}{l}\text { Update the } \\
\text { SAPHIRE } \\
\text { interface } \\
\text { design } \\
\text { specification } \\
\text { and program } \\
\text { plan }\end{array}$ & $\begin{array}{l}\text { Complete two } \\
\text { weeks after work } \\
\text { plan accepted. }\end{array}$ & & \\
\hline & \multicolumn{4}{|c|}{ Estimated Level of Effort General Release SAPHIRE 8: } \\
\hline
\end{tabular}


SOFTWARE PROJECT PLAN for SAPHIRE Version 8 N6423

$\begin{array}{ll}\text { Identifier: } & \text { INL/EXT-09-15853 } \\ \text { Revision: } & 4 \\ \text { Effective Date: } & 3 / 3 / 2010\end{array}$

\begin{tabular}{|c|c|c|c|c|}
\hline \multicolumn{5}{|c|}{ Support for SAPHIRE User Interfaces - Subtasks } \\
\hline & Subtask & Status/Milestones & $\begin{array}{l}\text { Staff- } \\
\text { months }\end{array}$ & Notes \\
\hline & $\begin{array}{l}\text { No work } \\
\text { specified. }\end{array}$ & & & \\
\hline \multirow[t]{4}{*}{$\begin{array}{l}\text { Address Beta Test } \\
\text { Comments - } \\
\text { SAPHIRE User } \\
\text { Interface Support }\end{array}$} & \multicolumn{4}{|c|}{ Estimated Level of Effort General Release SAPHIRE 8} \\
\hline & Subtask & Status/Milestones & $\begin{array}{l}\text { Staff- } \\
\text { months }\end{array}$ & Notes \\
\hline & UI-GR-1 & Start May 2008. & $\frac{\text { FY08 }}{1.0}$ & \\
\hline & $\begin{array}{l}\text { Address Beta } \\
\text { Test } \\
\text { Comments - } \\
\text { SAPHIRE User } \\
\text { Interface } \\
\text { Support }\end{array}$ & $\begin{array}{l}\text { Complete July } \\
2009 .\end{array}$ & $\frac{F Y 09}{1.5}$ & \\
\hline
\end{tabular}




\begin{tabular}{|c|c|c|}
\hline Idaho National Laboratory & & Page: 45 of 74 \\
\hline \multirow{3}{*}{$\begin{array}{l}\text { SOFTWARE PROJECT PLAN } \\
\text { for SAPHIRE Version } 8 \text { N6423 }\end{array}$} & Identifier: & INL/EXT-09-15853 \\
\hline & Revision: & 4 \\
\hline & Effective Date: & $3 / 3 / 2010$ \\
\hline
\end{tabular}

\begin{tabular}{|c|c|c|c|c|}
\hline \multicolumn{5}{|c|}{ Features and Capabilities - Subtasks } \\
\hline \multirow[t]{4}{*}{$\begin{array}{l}\text { Complete basic } \\
\text { functionality of } \\
\text { SAPHIRE } 8\end{array}$} & \multicolumn{4}{|c|}{$\begin{array}{l}\text { Estimated Level of Effort for First Beta SAPHIRE } 8 \\
\text { FY07 Included in Task } 6 \text { of N6423. (Task } 6 \text { Is } 5 \text { SM.) }\end{array}$} \\
\hline & Subtask & Status/Milestones & $\begin{array}{l}\text { Staff- } \\
\text { months }\end{array}$ & Notes \\
\hline & BF-B-1 & $\begin{array}{l}\text { Continuing } \\
\text { through January } \\
2008 \text { for the first } \\
\text { beta version. }\end{array}$ & $\begin{array}{l}\text { FY07 } \\
\text { Included } \\
\text { in Task } \\
6 \text { of }\end{array}$ & \\
\hline & $\begin{array}{l}\text { Examples } \\
\text { include drag } \\
\text { and drop } \\
\text { capability, } \\
\text { Word and } \\
\text { Excel reports, } \\
\text { graphical editor } \\
\text { work for fault } \\
\text { trees (user } \\
\text { control over } \\
\text { creating) and } \\
\text { event trees } \\
\text { (flag set } \\
\text { column for } \\
\text { viewing) etc. }\end{array}$ & & & \\
\hline \multirow[t]{3}{*}{$\begin{array}{l}\text { RASP common } \\
\text { cause failure } \\
\text { methodology } \\
\text { guidance }\end{array}$} & \multicolumn{4}{|c|}{$\begin{array}{l}\text { Estimated Level of Effort for First Beta SAPHIRE } 8 \\
\underline{\text { FY07 } 2 \text { SM (Includes carryover) }}\end{array}$} \\
\hline & Subtask & Status/Milestones & $\begin{array}{l}\text { Staff- } \\
\text { months }\end{array}$ & Notes \\
\hline & CC-B-1 & Completed by & $\underline{\text { FY07 }}$ & \\
\hline
\end{tabular}


SOFTWARE PROJECT PLAN for SAPHIRE Version 8 N6423

Identifier: INL/EXT-09-15853

Revision: $\quad 4$

Effective Date: 3/3/2010

\begin{tabular}{|c|c|c|c|c|}
\hline \multicolumn{5}{|c|}{ Features and Capabilities - Subtasks } \\
\hline & $\begin{array}{l}\text { RASP common } \\
\text { cause failure } \\
\text { methodology } \\
\text { guidance }\end{array}$ & Jan 30, 2008. & 2 & \\
\hline \multirow{8}{*}{$\begin{array}{l}\text { Increase } \\
\text { computational } \\
\text { speed }\end{array}$} & \multicolumn{4}{|c|}{$\begin{array}{l}\text { Estimated Level of Effort for First Beta SAPHIRE } 8 \\
\text { FY07 } 0\end{array}$} \\
\hline & Subtask & Status/Milestones & $\begin{array}{l}\text { Staff- } \\
\text { months }\end{array}$ & Notes \\
\hline & $\begin{array}{l}\text { No work } \\
\text { specified. }\end{array}$ & & & \\
\hline & \multicolumn{4}{|c|}{$\begin{array}{l}\text { Estimated Level of Effort General Release SAPHIRE } 8 \\
\underline{\text { FY08 } 2 \text { SM }} \underline{\text { FY09 } 2 \mathrm{SM}}\end{array}$} \\
\hline & Subtask & Status/Milestones & $\begin{array}{l}\text { Staff- } \\
\text { months }\end{array}$ & Notes \\
\hline & SP-GR-1 & & $\frac{F Y 08}{2 S M}$ & \\
\hline & $\begin{array}{l}\text { Improve code } \\
\text { speed by } \\
\text { updating the } \\
\text { sequence } \\
\text { recovery } \\
\text { algorithm. }\end{array}$ & $\begin{array}{l}\text { Complete by } \\
\text { September } 2008 .\end{array}$ & $\frac{\text { FY09 }}{0}$ & \\
\hline & SP-GR-2 & Start in FY09. & $\frac{\mathrm{FY} 08}{0}$ & $\begin{array}{l}\text { A proof-of-concept } \\
\text { study was performed }\end{array}$ \\
\hline
\end{tabular}




\section{SOFTWARE PROJECT PLAN for SAPHIRE Version 8 N6423}

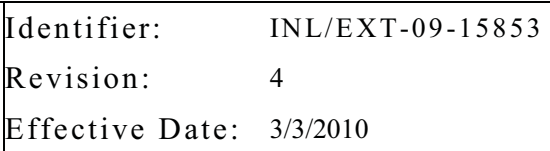

Effective Date: $3 / 3 / 2010$

\begin{tabular}{|c|c|c|c|c|}
\hline \multicolumn{2}{|c|}{ Features and Capabilities - Subtasks } & \multirow[b]{2}{*}{$\begin{array}{l}\text { Complete by July } \\
2009 .\end{array}$} & \multirow[b]{2}{*}{$\frac{F Y 09}{2 S M}$} & \multirow[b]{2}{*}{$\begin{array}{l}\text { for SAPHIRE } 8 \text { on a } \\
\text { multiprocessor } \\
\text { computer. This task } \\
\text { anticipates a possible } \\
\text { future upgrade of NRC } \\
\text { computers to dual unit } \\
\text { processors. }\end{array}$} \\
\hline & $\begin{array}{l}\text { Make SAPHIRE } \\
8 \text { compatible } \\
\text { with dual } \\
\text { processor } \\
\text { computers. }\end{array}$ & & & \\
\hline \multirow{4}{*}{$\begin{array}{l}\text { Address Beta Test } \\
\text { Comments - } \\
\text { Features and } \\
\text { Capabilities }\end{array}$} & \multicolumn{4}{|c|}{ Estimated Level of Effort General Release SAPHIRE 8: } \\
\hline & Subtask & Status/Milestones & $\begin{array}{l}\text { Staff- } \\
\text { months }\end{array}$ & Notes \\
\hline & FC-GR-1 & Start May 2008. & $\frac{\mathrm{FY} 08}{1}$ & \\
\hline & $\begin{array}{l}\text { Address Beta } \\
\text { Test Comments } \\
\text { - Features and } \\
\text { Capabilities }\end{array}$ & $\begin{array}{l}\text { Complete by July } \\
2009 .\end{array}$ & $\frac{F Y 09}{2}$ & \\
\hline
\end{tabular}


SOFTWARE PROJECT PLAN for SAPHIRE Version 8 N6423

Identifier: INL/EXT-09-15853

Revision: $\quad 4$

Effective Date: $3 / 3 / 2010$

\begin{tabular}{|c|c|c|c|c|}
\hline \multicolumn{5}{|c|}{ Quality Assurance - Subtasks } \\
\hline \multirow{6}{*}{$\begin{array}{l}\text { Software } \\
\text { Verification and } \\
\text { Validation Plan } \\
\text { Completion and } \\
\text { Maintenance }\end{array}$} & \multicolumn{4}{|c|}{$\begin{array}{l}\text { Estimated Level of Effort for First Beta SAPHIRE } 8 \\
\text { FY07 Included in all Tasks of N6423 }\end{array}$} \\
\hline & Subtask & Status/Milestones & $\begin{array}{l}\text { Staff- } \\
\text { months }\end{array}$ & Notes \\
\hline & $\begin{array}{l}\text { Reach a } \\
\text { consensus on } \\
\text { the target } \\
\text { software } \\
\text { integrity level } \\
{[1,2,3 \text {, or } 4]}\end{array}$ & $\begin{array}{l}\text { Proposed level } \\
\text { with justification } \\
\text { to be provided } \\
\text { with work } \\
\text { development } \\
\text { plan. }\end{array}$ & $\begin{array}{l}\text { FY07 } \\
\text { Included } \\
\text { in Task } \\
1 \text { of } \\
\text { N6423. }\end{array}$ & $\begin{array}{l}\text { Approval of work } \\
\text { development plan will } \\
\text { reach a consensus on } \\
\text { the level. The level will } \\
\text { serve to help the } \\
\text { Software Verification } \\
\text { and Validation Plan } \\
\text { identify what activities } \\
\text { shall and shall not be } \\
\text { performed (see subtask } \\
\text { below). }\end{array}$ \\
\hline & VV-B-2 & \multirow{2}{*}{$\begin{array}{l}\text { Continue to } \\
\text { update and } \\
\text { maintain during } \\
\text { the first } \\
\text { SAPHIRE } 8 \text { beta } \\
\text { version } \\
\text { development. }\end{array}$} & \multirow{2}{*}{$\begin{array}{l}\text { FY07 } \\
\text { Included } \\
\text { in all } \\
\text { Tasks of } \\
\text { N6423. }\end{array}$} & \multirow[t]{2}{*}{$\begin{array}{l}\text { Details will be provided } \\
\text { in the Software } \\
\text { Verification and } \\
\text { Validation Plan. }\end{array}$} \\
\hline & $\begin{array}{l}\text { Create a formal } \\
\text { Software } \\
\text { Verification and } \\
\text { Validation Plan } \\
\text { document that } \\
\text { describes which } \\
\text { V\&V activities } \\
\text { shall and shall } \\
\text { not be } \\
\text { performed. }\end{array}$ & & & \\
\hline & VV-B-3 & To start in FY08. & $\frac{\text { FY07 }}{\text { Included }}$ & $\begin{array}{l}\text { Details will be provided } \\
\text { in the Software }\end{array}$ \\
\hline
\end{tabular}


SOFTWARE PROJECT PLAN for SAPHIRE Version 8 N6423

Identifier: INL/EXT-09-15853

Revision: $\quad 4$

Effective Date: $3 / 3 / 2010$

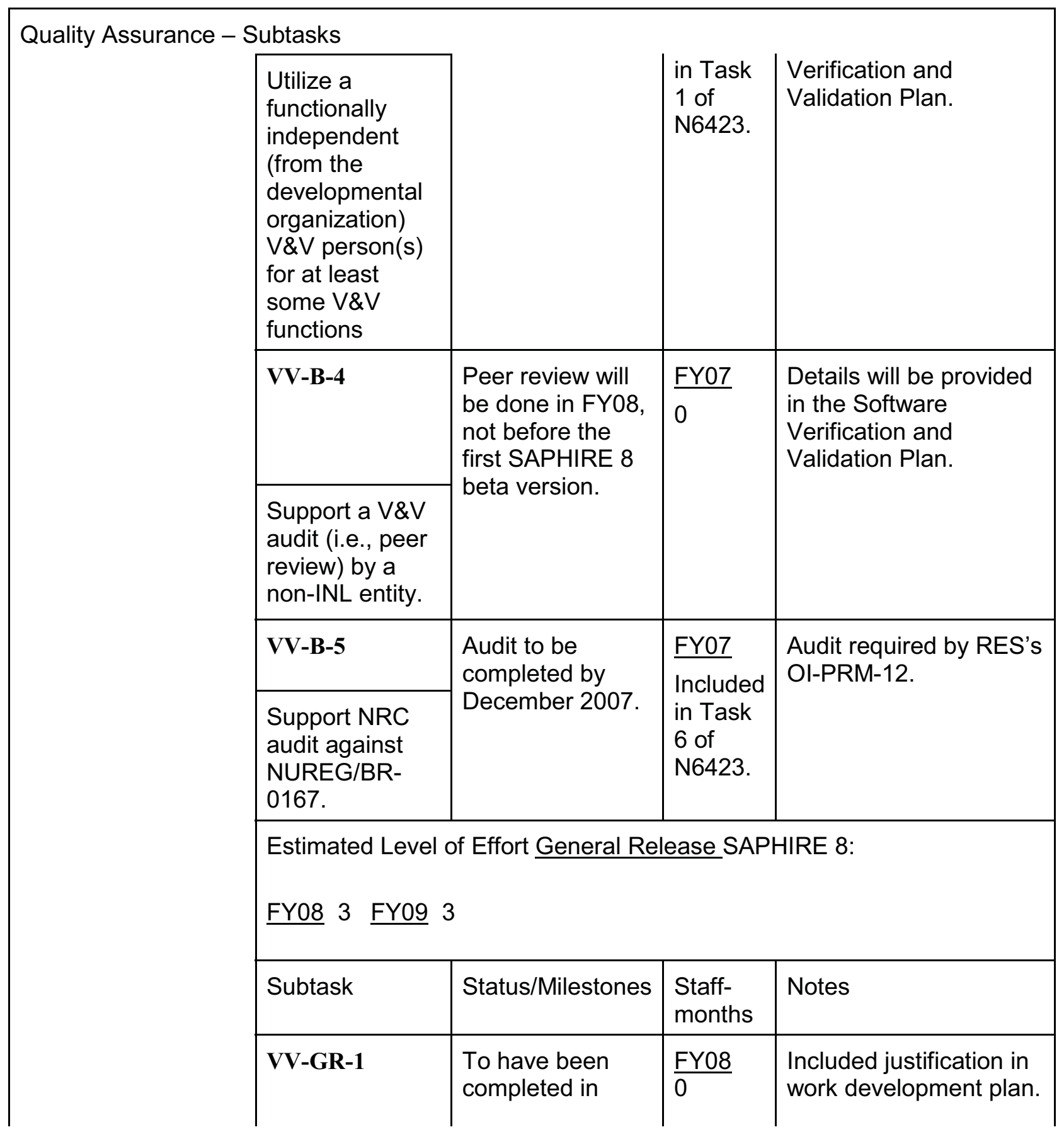




\section{SOFTWARE PROJECT PLAN for SAPHIRE Version 8 N6423}

$\begin{array}{ll}\text { Identifier: } & \text { INL/EXT-09-15853 } \\ \text { Revision: } & 4 \\ \text { Effective Date: } & 3 / 3 / 2010\end{array}$

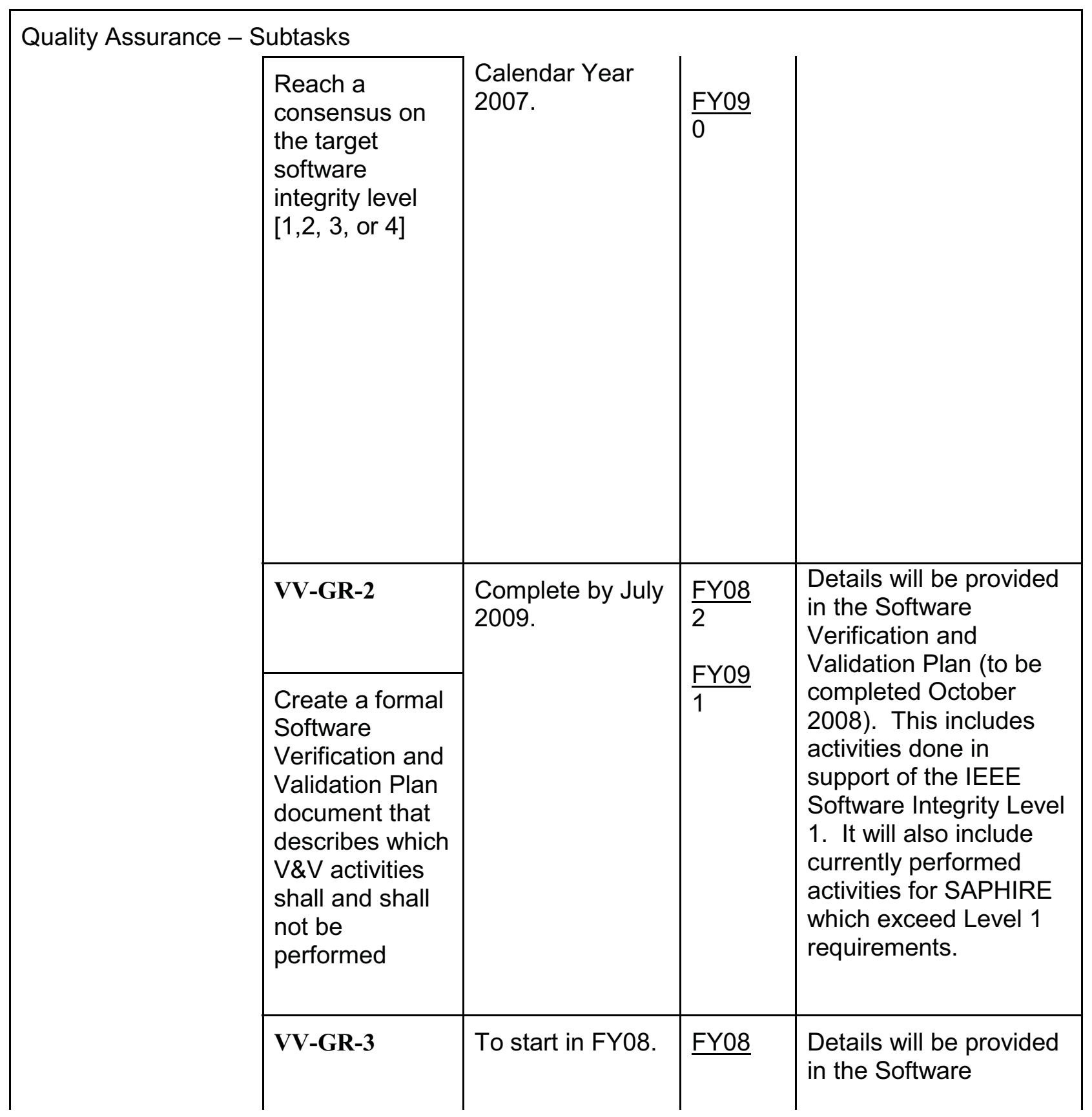


SOFTWARE PROJECT PLAN for SAPHIRE Version 8 N6423

Identifier: INL/EXT-09-15853

Revision: $\quad 4$

Effective Date: $3 / 3 / 2010$

\begin{tabular}{|c|c|c|c|c|}
\hline \multicolumn{5}{|c|}{ Quality Assurance - Subtasks } \\
\hline & $\begin{array}{l}\text { Utilize a } \\
\text { functionally } \\
\text { independent } \\
\text { (from the } \\
\text { developmental } \\
\text { organization) } \\
\text { V\&V person(s) } \\
\text { for at least } \\
\text { some V\&V } \\
\text { functions }\end{array}$ & & $\begin{array}{l}1 \\
\underline{\text { FY09 }} \\
1\end{array}$ & $\begin{array}{l}\text { Verification and } \\
\text { Validation Plan. }\end{array}$ \\
\hline & VV-GR-4 & \multirow[t]{2}{*}{$\begin{array}{l}\text { Complete by } \\
\text { November } 2008 .\end{array}$} & \multirow{2}{*}{$\begin{array}{l}\frac{F Y 08}{0.5} \\
\frac{F Y 09}{0.5}\end{array}$} & \multirow{2}{*}{$\begin{array}{l}\text { Details will be provided } \\
\text { in the Software } \\
\text { Verification and } \\
\text { Validation Plan. }\end{array}$} \\
\hline & $\begin{array}{l}\text { Support a V\&V } \\
\text { audit (i.e., peer } \\
\text { review) by a } \\
\text { non-INL entity. }\end{array}$ & & & \\
\hline & VV-GR-5 & \multirow{2}{*}{$\begin{array}{l}\text { Audit to be } \\
\text { completed by } \\
\text { December } 2008 . \\
\text { Audit to be } \\
\text { completed by } \\
\text { December } 2009 .\end{array}$} & $\frac{\text { FY08 }}{0.5}$ & \multirow[t]{2}{*}{$\begin{array}{l}\text { Audit required by RES's } \\
\text { OI-PRM-12. }\end{array}$} \\
\hline & $\begin{array}{l}\text { Support NRC } \\
\text { audit against } \\
\text { NUREG/BR- } \\
0167\end{array}$ & & $\frac{\text { FY09 }}{0.5}$ & \\
\hline \multirow{5}{*}{$\begin{array}{l}\text { Testing, } \\
\text { Verification, and } \\
\text { Validation } \\
\text { Augmentation }\end{array}$} & \multicolumn{4}{|c|}{$\begin{array}{l}\text { Estimated Level of Effort for First Beta SAPHIRE 8: } \\
\text { FY07 Included in tasks of N6423. }\end{array}$} \\
\hline & Subtask & Status/Milestones & $\begin{array}{l}\text { Staff- } \\
\text { months }\end{array}$ & Notes \\
\hline & AU-B-1 & \multirow{2}{*}{$\begin{array}{l}\text { Complete by } \\
\text { January } 31 \\
2008 .\end{array}$} & \multirow{2}{*}{$\begin{array}{l}\text { FY07 } \\
\text { Included } \\
\text { in tasks } \\
\text { of } \\
\text { N6423. }\end{array}$} & \\
\hline & $\begin{array}{l}\text { Identify, } \\
\text { document, and } \\
\text { implement } \\
\text { tests. }\end{array}$ & & & \\
\hline & \multicolumn{4}{|c|}{$\begin{array}{l}\text { Estimated Level of Effort General Release SAPHIRE 8: } \\
\text { FY08 } 2 \text { FY09 } 2\end{array}$} \\
\hline
\end{tabular}


SOFTWARE PROJECT PLAN for SAPHIRE Version 8 N6423

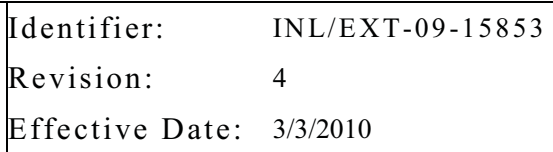

\begin{tabular}{|c|c|c|c|c|}
\hline \multicolumn{5}{|c|}{ Quality Assurance - Subtasks } \\
\hline & Subtask & Status/Milestones & $\begin{array}{l}\text { Staff- } \\
\text { months }\end{array}$ & Notes \\
\hline & AU-GR-1 & \multirow[t]{2}{*}{$\begin{array}{l}\text { Complete by July } \\
2009 .\end{array}$} & \multirow{2}{*}{$\begin{array}{l}\frac{F Y 08}{2} \\
\frac{F Y 09}{2}\end{array}$} & \multirow{2}{*}{$\begin{array}{l}\text { Required to test new } \\
\text { features and new } \\
\text { interface. }\end{array}$} \\
\hline & $\begin{array}{l}\text { Augment the } \\
\text { test suite }\end{array}$ & & & \\
\hline \multirow[t]{8}{*}{ Bug Fixes } & \multicolumn{4}{|c|}{$\begin{array}{l}\text { Estimated Level of Effort for First Beta SAPHIRE 8: } \\
\text { FY07 Included in Task } 6 \text { of N6423. (Task } 6 \text { is } 5 \text { SM.) }\end{array}$} \\
\hline & Subtask & Status/Milestones & $\begin{array}{l}\text { Staff- } \\
\text { months }\end{array}$ & Notes \\
\hline & BF-B-1 & \multirow{2}{*}{$\begin{array}{l}\text { Continuous } \\
\text { subtask. }\end{array}$} & \multirow{2}{*}{$\begin{array}{l}\frac{\text { FY07 }}{\text { Included }} \\
\text { in Task } \\
6 \text { of } \\
\text { N6423. }\end{array}$} & \\
\hline & Bug Fixes & & & \\
\hline & \multicolumn{4}{|c|}{$\begin{array}{l}\text { Estimated Level of Effort General Release SAPHIRE } 8 \\
\text { FY08 } 3 \text { SM } \underline{\text { FY09 } 3 \mathrm{SM}}\end{array}$} \\
\hline & Subtask & Status/Milestones & $\begin{array}{l}\text { Staff- } \\
\text { months }\end{array}$ & Notes \\
\hline & BF-GR-1 & $\begin{array}{l}\text { Continuous } \\
\text { subtask. }\end{array}$ & $\frac{\mathrm{FY} 08}{3}$ & $\begin{array}{l}\text { Maintenance and } \\
\text { general support that is }\end{array}$ \\
\hline & Bug Fixes & & $\frac{\text { FY09 }}{3}$ & \\
\hline $\begin{array}{l}\text { Legacy code } \\
\text { review and walk } \\
\text { down }\end{array}$ & \multicolumn{4}{|c|}{ Estimated Level of Effort for First Beta SAPHIRE 8} \\
\hline
\end{tabular}


SOFTWARE PROJECT PLAN for SAPHIRE Version 8 N6423

Identifier: INL/EXT-09-15853

Revision: $\quad 4$

Effective Date: $3 / 3 / 2010$

\begin{tabular}{|c|c|c|c|c|}
\hline \multicolumn{5}{|c|}{ Quality Assurance - Subtasks } \\
\hline & Subtask & Status/Milestones & $\begin{array}{l}\text { Staff- } \\
\text { months }\end{array}$ & Notes \\
\hline & $\begin{array}{l}\text { No work } \\
\text { specified. }\end{array}$ & & & \\
\hline & \multicolumn{4}{|c|}{$\begin{array}{l}\text { Estimated Level of Effort General Release SAPHIRE } 8 \\
\underline{\text { FY08 }} 1 \underline{\text { FY09 }} 1\end{array}$} \\
\hline & Subtask & Status/Milestones & $\begin{array}{l}\text { Staff- } \\
\text { months }\end{array}$ & Notes \\
\hline & LC-GR-1 & $\begin{array}{l}\text { Continues } \\
\text { through general }\end{array}$ & $\frac{\mathrm{FY} 08}{1}$ & $\begin{array}{l}\text { Detailed review and } \\
\text { walk down of the code }\end{array}$ \\
\hline & $\begin{array}{l}\text { Legacy code } \\
\text { review and walk } \\
\text { down }\end{array}$ & $\begin{array}{l}\text { SAPHIRE } 8 \text { by } \\
\text { July } 2009 .\end{array}$ & $\frac{\mathrm{FY} 09}{1}$ & maintenance. \\
\hline \multirow{5}{*}{$\begin{array}{l}\text { Port code into } \\
\text { Delphi }\end{array}$} & \multirow{2}{*}{\multicolumn{4}{|c|}{ Estimated Level of Effort for First Beta SAPHIRE 8}} \\
\hline & & & & \\
\hline & Subtask & Status/Milestones & $\begin{array}{l}\text { Staff- } \\
\text { months }\end{array}$ & Notes \\
\hline & $\begin{array}{l}\text { No work } \\
\text { specified. }\end{array}$ & & & \\
\hline & \multicolumn{4}{|c|}{ 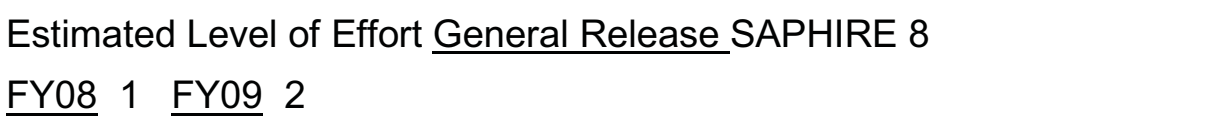 } \\
\hline
\end{tabular}


SOFTWARE PROJECT PLAN for SAPHIRE Version 8 N6423

$\begin{array}{ll}\text { Identifier: } & \text { INL/EXT-09-15853 } \\ \text { Revision: } & 4 \\ \text { Effective Date: } & 3 / 3 / 2010\end{array}$

\begin{tabular}{|c|c|c|c|c|}
\hline \multicolumn{5}{|c|}{ Quality Assurance - Subtasks } \\
\hline & Subtask & Status/Milestones & $\begin{array}{l}\text { Staff- } \\
\text { months }\end{array}$ & Notes \\
\hline & PO-GR-1 & \multirow{2}{*}{$\begin{array}{l}\text { Continues } \\
\text { through general } \\
\text { release of } \\
\text { SAPHIRE } 8 \text { by } \\
\text { July } 2009 .\end{array}$} & $\frac{\mathrm{FY} 08}{1}$ & \multirow[t]{2}{*}{$\begin{array}{l}\text { Needed to improve } \\
\text { code maintenance. }\end{array}$} \\
\hline & $\begin{array}{l}\text { Port code into } \\
\text { Delphi }\end{array}$ & & $\frac{\text { FY09 }}{2}$ & \\
\hline \multirow[t]{7}{*}{ Risk API Support } & \multicolumn{4}{|c|}{$\begin{array}{l}\text { Estimated Level of Effort for First Beta SAPHIRE } 8 \\
\text { FY07 } 0\end{array}$} \\
\hline & Subtask & Status/Milestones & $\begin{array}{l}\text { Staff- } \\
\text { months }\end{array}$ & Notes \\
\hline & $\begin{array}{l}\text { No work } \\
\text { specified. }\end{array}$ & & & \\
\hline & \multicolumn{4}{|c|}{ 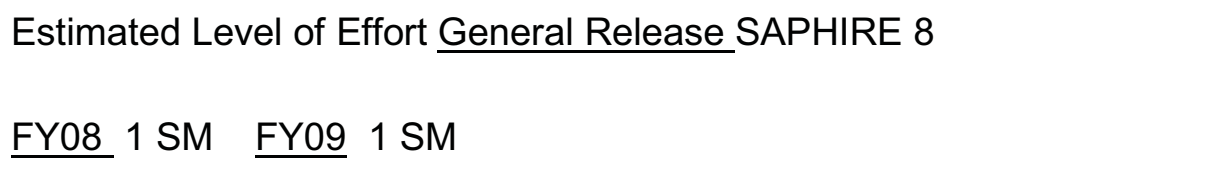 } \\
\hline & Subtask & Status/Milestones & $\begin{array}{l}\text { Staff- } \\
\text { months }\end{array}$ & Notes \\
\hline & RA-GR-1 & $\begin{array}{l}\text { Continuous } \\
\text { subtask. }\end{array}$ & $\frac{\mathrm{FY} 08}{1 \mathrm{SM}}$ & $\begin{array}{l}\text { This activity is } \\
\text { necessary to maintain } \\
\text { the code. }\end{array}$ \\
\hline & $\begin{array}{l}\text { Risk API } \\
\text { Support }\end{array}$ & & $\frac{F Y 09}{1 S M}$ & \\
\hline \multirow[t]{2}{*}{$\begin{array}{l}\text { Ensure accurate } \\
\text { CCF basic event } \\
\text { probabilities }\end{array}$} & \multicolumn{4}{|c|}{ Estimated Level of Effort General Release SAPHIRE 8} \\
\hline & Subtask & Status/Milestones & $\begin{array}{l}\text { Staff- } \\
\text { months }\end{array}$ & Notes \\
\hline
\end{tabular}




\section{SOFTWARE PROJECT PLAN} for SAPHIRE Version 8 N6423

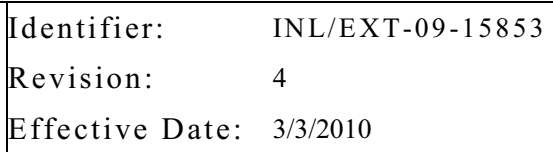

Effective Date: $3 / 3 / 2010$

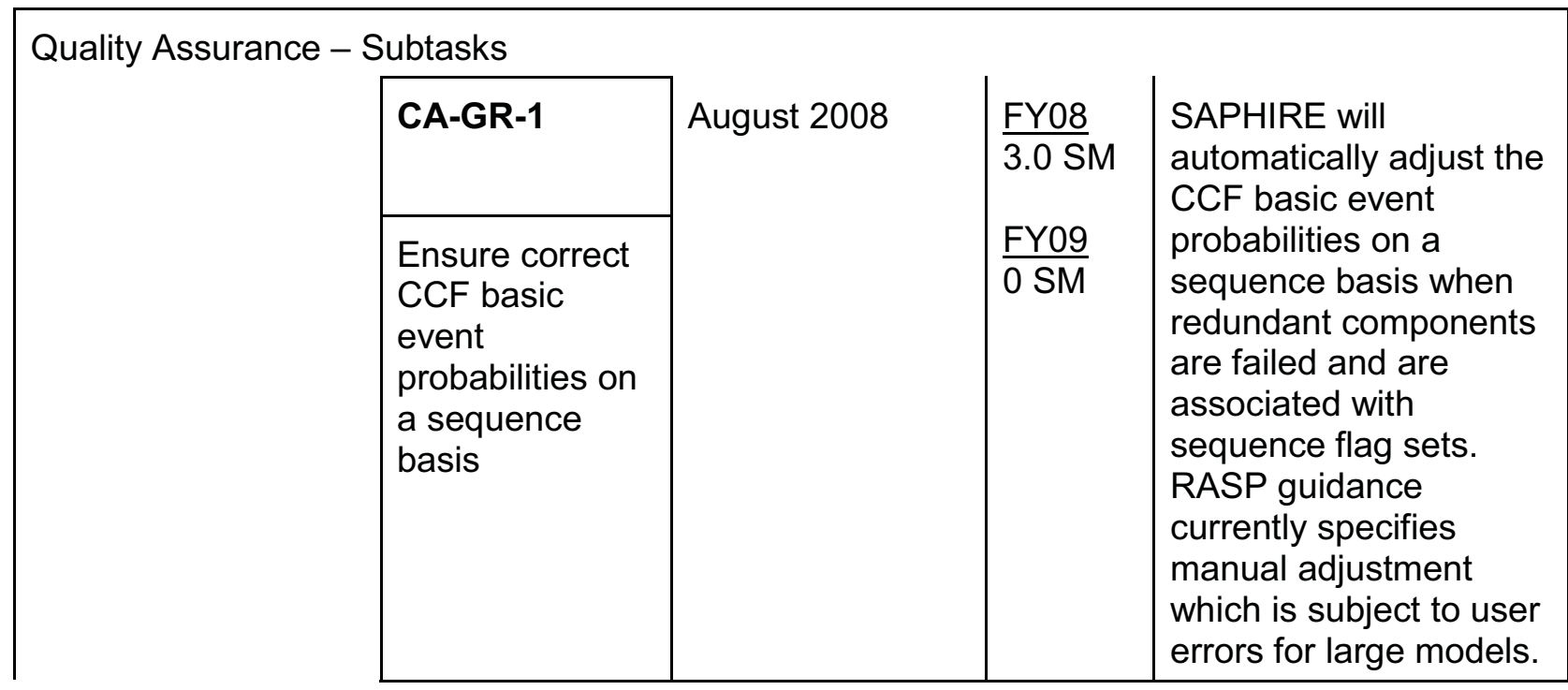


SOFTWARE PROJECT PLAN for SAPHIRE Version 8 N6423

Identifier: INL/EXT-09-15853

Revision: $\quad 4$

Effective Date: $3 / 3 / 2010$

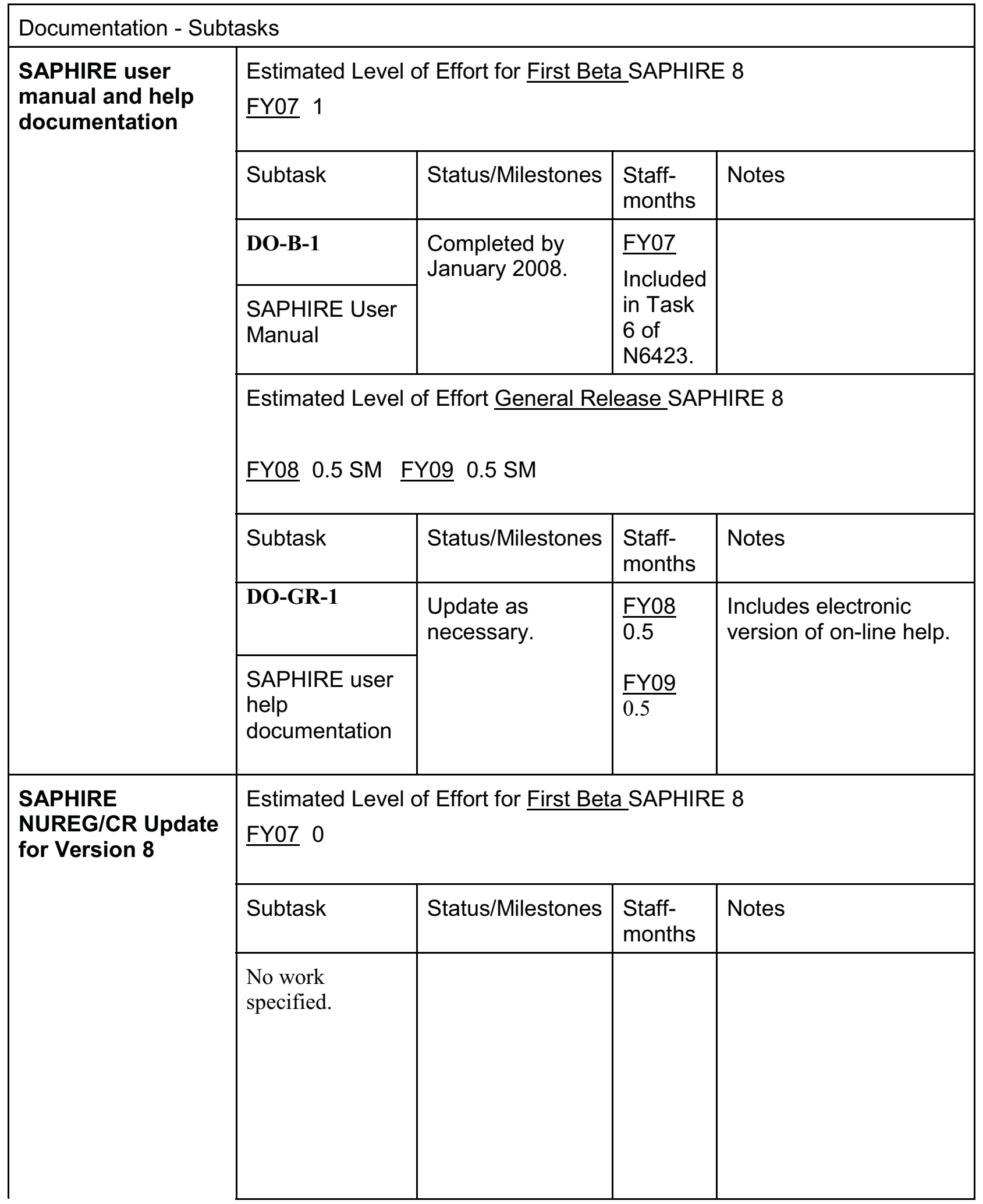




\section{SOFTWARE PROJECT PLAN} for SAPHIRE Version 8 N6423

$\begin{array}{ll}\text { Identifier: } & \text { INL/EXT-09-15853 } \\ \text { Revision: } & 4 \\ \text { Effective Date: } & 3 / 3 / 2010\end{array}$

\begin{tabular}{|c|c|c|c|c|}
\hline \multicolumn{5}{|c|}{ Documentation - Subtasks } \\
\hline & \multicolumn{4}{|c|}{ 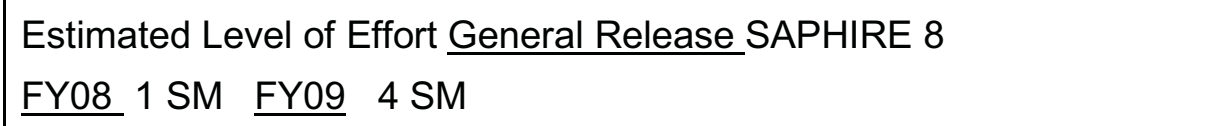 } \\
\hline & Subtask & Status/Milestones & $\begin{array}{l}\text { Staff- } \\
\text { months }\end{array}$ & Notes \\
\hline & DO-GR-2 & $\begin{array}{l}\text { Draft to NRC PM, } \\
\text { April } 2009 .\end{array}$ & $\frac{\mathrm{FY} 08}{2.5 \mathrm{SM}}$ & $\begin{array}{l}\text { Include update to the } \\
\text { technical reference }\end{array}$ \\
\hline & $\begin{array}{l}\text { SAPHIRE } \\
\text { NUREG/CR } \\
\text { Update for } \\
\text { Version } 8\end{array}$ & & $\frac{\mathrm{FY} 09}{4}$ & $\begin{array}{l}\text { may affect results. This } \\
\text { update (in 2008) will be } \\
\text { documented in a ACRS } \\
\text { briefing package an } \\
\text { ACRS presentation in } \\
2008 \text {. }\end{array}$ \\
\hline
\end{tabular}




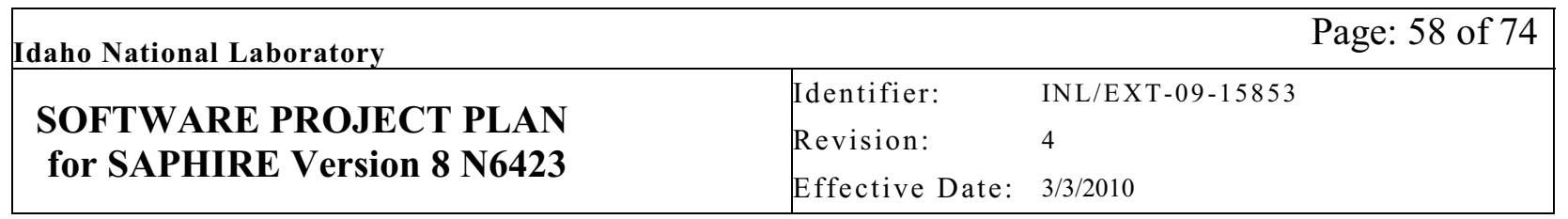

\section{OTHER WORK TO BE CONSIDERED}




\begin{tabular}{|c|c|c|c|}
\hline Task Title & Task Description & Task Benefits & Level of Effort \\
\hline $\begin{array}{l}\text { Binary Decision } \\
\text { Diagrams }\end{array}$ & $\begin{array}{l}\text { A way to improve } \\
\text { the cut set } \\
\text { quantification } \\
\text { routines through } \\
\text { binary decision } \\
\text { diagrams. }\end{array}$ & $\begin{array}{l}\text { BDDs determine an exact } \\
\text { probability for a top event. Study } \\
\text { of BDDs is needed. } \\
\text { Implementation is dependent on } \\
\text { study. }\end{array}$ & $\begin{array}{l}\text { Solving } 3 \text { staff } \\
\text { months } \\
\text { Quantifying } 1 \\
\text { staff month }\end{array}$ \\
\hline $\begin{array}{l}\text { Flag set } \\
\text { modification of } \\
\text { basic events }\end{array}$ & $\begin{array}{l}\text { Modify basic event } \\
\text { probabilities from } \\
\text { flag sets (other than } \\
\mathrm{T}, \mathrm{F} \text {, or I). }\end{array}$ & $\begin{array}{l}\text { One approach for retaining cut } \\
\text { sets that may be truncated out } \\
\text { prior to changing the basic event } \\
\text { probability via recovery rules. }\end{array}$ & 3 staff months \\
\hline $\begin{array}{l}\text { Reverse } \\
\text { Accident } \\
\text { Sequence Matrix } \\
\text { (ASM) capability }\end{array}$ & $\begin{array}{l}\text { A way of putting the } \\
\text { models into ASM } \\
\text { format. }\end{array}$ & $\begin{array}{l}\text { Allows easy modification of model } \\
\text { inputs, including defining model } \\
\text { types. }\end{array}$ & TBD \\
\hline $\begin{array}{l}\text { OW-4 } \\
\text { CCF event tree } \\
\text { within compound } \\
\text { basic event. }\end{array}$ & $\begin{array}{l}\text { Use Boolean logic } \\
\text { to calculate CCF } \\
\text { probabilities. }\end{array}$ & $\begin{array}{l}\text { Helps to compare CCF } \\
\text { probabilities with other PRAs. }\end{array}$ & TBD \\
\hline $\begin{array}{l}\text { Include } \\
\text { convolution } \\
\text { event for time } \\
\text { dependent } \\
\text { calculations. } \\
\end{array}$ & $\begin{array}{l}\text { Provide a general } \\
\text { capability to perform } \\
\text { convolution } \\
\text { integration }\end{array}$ & $\begin{array}{l}\text { Older versions of GEM had a built- } \\
\text { in (i.e., hard wired, not general } \\
\text { capability) convolution calculation } \\
\text { for the offsite power non-recovery } \\
\text { calculations. This capability would } \\
\text { provide that capability. }\end{array}$ & 1.5 staff months \\
\hline $\begin{array}{l}\text { Success Branch } \\
\text { and Non- } \\
\text { coherent Logic } \\
\text { Treatment }\end{array}$ & $\begin{array}{l}\text { A way to better } \\
\text { handle non- } \\
\text { coherent logic and } \\
\text { the treatment of } \\
\text { success sequences } \\
\text { or systems. }\end{array}$ & $\begin{array}{l}\text { Ensures a correct solution for } \\
\text { which approximation calculation } \\
\text { methods may not apply. Such } \\
\text { methods have already been } \\
\text { studied (see NUREG/CR-5242 } \\
\text { and NUREG/CR-4800). }\end{array}$ & 2 staff months \\
\hline
\end{tabular}




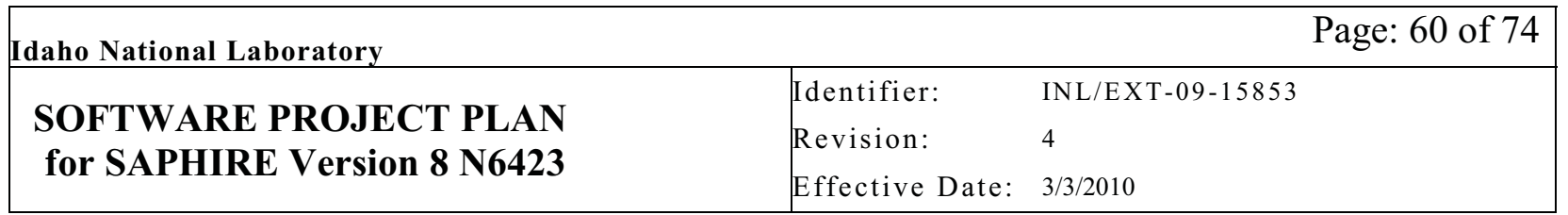

\begin{tabular}{|c|c|c|c|}
\hline OW-7 & \multirow{2}{*}{$\begin{array}{l}\text { A way to store and } \\
\text { analyze reliability } \\
\text { data using Bayes } \\
\text { Theorem. }\end{array}$} & \multirow{2}{*}{$\begin{array}{l}\text { Provides a means to perform a } \\
\text { quick update of reliabilities for } \\
\text { timely analyses. }\end{array}$} & \multirow[t]{2}{*}{2.5 staff months } \\
\hline $\begin{array}{l}\text { Bayesian Data } \\
\text { Analysis }\end{array}$ & & & \\
\hline OW-8 & \multirow[t]{2}{*}{$\begin{array}{l}\text { A way for SAPHIRE } \\
\text { to interface with } \\
\text { QRAS (two-way } \\
\text { data exchange) }\end{array}$} & \multirow{2}{*}{$\begin{array}{l}\text { Extends the capabilities of } \\
\text { SAPHIRE to utilize QRAS. } \\
\text { Benefits for analyses would } \\
\text { require a study of QRAS } \\
\text { capabilities and interfacing QRAS } \\
\text { with SAPHIRE. Implementation is } \\
\text { dependent on study. }\end{array}$} & \multirow[t]{2}{*}{2.5 staff months } \\
\hline $\begin{array}{l}\text { Support for Data } \\
\text { Exchange }\end{array}$ & & & \\
\hline OW-9 & \multirow{2}{*}{$\begin{array}{l}\text { A way to rank } \\
\text { events according to } \\
\text { their contribution } \\
\text { both to the } \\
\text { frequency of the end } \\
\text { state and to the } \\
\text { uncertainty in this } \\
\text { frequency }\end{array}$} & \multirow[t]{2}{*}{ New insights could be obtained } & \multirow[t]{2}{*}{1.5 staff months } \\
\hline $\begin{array}{l}\text { Generation of } \\
\text { Uncertainty } \\
\text { Importance } \\
\text { Ranking }\end{array}$ & & & \\
\hline OW-10 & \multirow{2}{*}{$\begin{array}{l}\text { A way to expose a } \\
\text { simple scripting type } \\
\text { of code so users } \\
\text { can develop custom } \\
\text { probability } \\
\text { calculations. }\end{array}$} & \multirow[t]{2}{*}{ Generalizes use of SAPHIRE. } & \multirow[t]{2}{*}{1.25 staff months } \\
\hline $\begin{array}{l}\text { General Purpose } \\
\text { Compound } \\
\text { Event Module }\end{array}$ & & & \\
\hline OW-11 & \multirow[t]{2}{*}{$\begin{array}{l}\text { A way to better } \\
\text { handle logic loops }\end{array}$} & \multirow{2}{*}{$\begin{array}{l}\text { Study current logic loop treatment } \\
\text { to identify potential benefits. } \\
\text { Implementation is dependent on } \\
\text { study. }\end{array}$} & \multirow[t]{2}{*}{2 staff months } \\
\hline $\begin{array}{l}\text { Logic Loop } \\
\text { Treatment }\end{array}$ & & & \\
\hline OW-12 & \multirow{2}{*}{$\begin{array}{l}\text { A way to build } \\
\text { representative } \\
\text { RBDs and turn them } \\
\text { into (internally) logic } \\
\text { structures for } \\
\text { solving. }\end{array}$} & \multirow[t]{2}{*}{$\begin{array}{l}\text { Study RBDs to identify potential } \\
\text { benefits. Implementation is } \\
\text { dependent on study. }\end{array}$} & \multirow[t]{2}{*}{3 staff months } \\
\hline $\begin{array}{l}\text { Reliability Block } \\
\text { Diagram Editor } \\
\text { and Solver }\end{array}$ & & & \\
\hline
\end{tabular}




\begin{tabular}{|l|l|l|l|} 
OW-13 & $\begin{array}{l}\text { A way to build } \\
\text { representative } \\
\text { ESDs and turn them } \\
\text { into (internally) logic } \\
\text { structures for } \\
\text { solving. }\end{array}$ & $\begin{array}{l}\text { Study ESDs to identify potential } \\
\text { benefits. Implementation is } \\
\text { dependent on study. }\end{array}$ & 3 staff months \\
$\begin{array}{l}\text { Event Sequence } \\
\text { Diagram Editor } \\
\text { and Solver }\end{array}$ & & \\
\hline
\end{tabular}

\section{Quality Assurance Recommendations}

\section{Target Software Integrity Level for SAPHIRE Version 8}

Proposed IEEE Software Integrity Level: 1

Justification:

The proposed SAPHIRE Software Integrity Level 1 is based on the following information derived from the NUREG/BR-0167 and the IEEE-1012 standards. Level definitions are provided below as a reference. From the NUREG evaluation, SAPHIRE is considered a "1", the highest level due to the potential contribution to the decision-making process.

SAPHIRE is at IEEE integrity level "1", the lowest. If one examines the IEEE software integrity level table, SAPHIRE can be assigned an IEEE-1012 level of 1 and still be critical to supporting the decision-making process. Because SAPHIRE is not the only tool used to support the decision-making process it should not be classified as "Catastrophic." Furthermore, no metrics to support an IEEE-1012 classification higher than a "1" currently exist. The results of any calculation information from SAPHIRE depend largely on how a model has been implemented by a user. A process exists to analyze all errors reported by the user community. The functionally independent V\&V check to be performed for SAPHIRE 8 will be able to provide feedback for the quality assurance process based on the errors reported. A detailed list of the activities that the SAPHIRE 8 development team performs to meet the IEEE-1012 integrity level proposed will be included in the Software Verification and Validation Plan.

Table 2. The NUREG/BR-0167 levels.

\begin{tabular}{|c|l|}
\hline $\begin{array}{l}\text { NUREG } \\
\text { Level }\end{array}$ & Description \\
\hline $\mathbf{1}$ & $\begin{array}{l}\text { Software-Technical application software used in a safety decision by the NRC (an } \\
\text { example would be RELAP5) }\end{array}$ \\
\hline $\mathbf{2}$ & Software-Technical or non-technical application software not used in a safety \\
\hline
\end{tabular}




\begin{tabular}{|c|l|}
\hline 3 & decision by the NRC (an example would be an agency financial software system). \\
\hline $\begin{array}{l}\text { Software-Technical or non-technical application software not used in a safety } \\
\text { decision and having local or limited use by the NRC (examples would include a } \\
\text { macro for Lotus 1-2-3). }\end{array}$ \\
\hline
\end{tabular}

Table 3. The IEEE Software Integrity levels.

\begin{tabular}{|c|l|}
\hline $\begin{array}{l}\text { Integrity } \\
\text { Level }\end{array}$ & Description \\
\hline $\mathbf{4}$ & $\begin{array}{l}\text { An error or function or system feature that causes critical consequences with } \\
\text { reasonable or probable likelihood of occurrence of an operating state that } \\
\text { contributes to the error. }\end{array}$ \\
\hline $\mathbf{3}$ & $\begin{array}{l}\text { An error or function or system feature that causes marginal consequences with } \\
\text { reasonable or probable likelihood of occurrence of an operating state that } \\
\text { contributes to the error. }\end{array}$ \\
\hline $\mathbf{2}$ & $\begin{array}{l}\text { An error or function or system feature that causes negligible consequences with } \\
\text { reasonable or probable likelihood of occurrence of an operating state that } \\
\text { contributes to the error. }\end{array}$ \\
\hline $\mathbf{1}$ & $\begin{array}{l}\text { An error or function or system feature that causes negligible consequences with } \\
\text { probable, occasional, or infrequent likelihood of occurrence of an operating state } \\
\text { that contributes to the error. }\end{array}$ \\
\hline
\end{tabular}

Table 4. The IEEE definitions of consequences.

\begin{tabular}{|l|l|}
\hline Consequence & Definitions \\
\hline Catastrophic & $\begin{array}{l}\text { Loss of human life, complete mission failure, loss of system security and } \\
\text { safety, or extensive financial or social loss. }\end{array}$ \\
\hline Critical & $\begin{array}{l}\text { Major and permanent injury, partial loss of mission, major system damage, or } \\
\text { major financial or social loss. }\end{array}$ \\
\hline Marginal & $\begin{array}{l}\text { Severe injury or illness, degradation of secondary mission, or some financial or } \\
\text { social loss. }\end{array}$ \\
\hline Negligible & $\begin{array}{l}\text { Minor injury or illness, minor impact on system performance, or operator } \\
\text { inconvenience. }\end{array}$ \\
\hline
\end{tabular}


Table 5. The IEEE Software Integrity levels map onto the error consequence levels.

\begin{tabular}{|l|c|c|c|c|}
\hline Error consequence & \multicolumn{4}{l|}{$\begin{array}{l}\text { Likelihood of occurrence of an operating state } \\
\text { that contributes to the error }\end{array}$} \\
\hline & Reasonable & Probable & Occasional & Infrequent \\
\hline Catastrophic & 4 & 4 & 4 or 3 & 3 \\
\hline Critical & 4 & 4 or 3 & 3 & 2 or 1 \\
\hline Marginal & 3 & 3 or 2 & 2 or 1 & 1 \\
\hline Negligible & 2 & 2 or 1 & 1 & 1 \\
\hline
\end{tabular}

Create a formal Software Validation and Verification Plan document that describes which V\&V activities will be performed, and which will not.

The SVVP Section 6 discuses the test methodology and strategy used. This section does not discuss what $\mathrm{V} \& \mathrm{~V}$ activities are being done other than running the tests. For example, there should be formal recordings of any V\&V activities beyond the tests and corresponding results. The SAPHIRE team does many more activities and should more formally track them so a visible record exists Activities that can easily be more formally tracked are formal reviews of new software objects, and configuration audits performed by an independent entity whether INL or non-INL. In order to formalize reviews, these items must be tracked:

Products associated with each formal review are:

1. The documents to be reviewed (e.g., the software requirements documentation for the Software Requirements Review)

2. The agenda for the review

3. The hardcopy presentation materials

4. The minutes that document the activities and results of the review

5. The updated documents that were reviewed

The SVVP will include activities done in support of the IEEE Software Integrity Level 1. It will also include currently performed activities for SAPHIRE which exceed Level 1 requirements.

\section{Utilize functionally independent Verification and Validation (V\&V) person for at least some of the $V \& V$ functions}

There are INL personnel outside the Risk, Reliability and NRC Programs department qualified to perform in this capacity. Information and resumes are stored and will be provided upon request.

V\&V activities to be performed by a functionally independent V\&V person at the INL are as follows. The activities will support the IEEE-1012 proposed integrity level 1 designation. Some activities are:

- Verification that requirements and high-level design have been reviewed and accepted or follow-up if revision is needed 


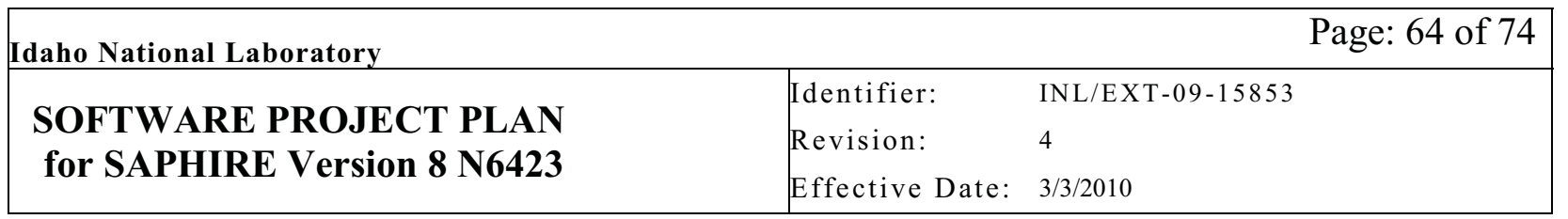

- Verification that the code implementation and test procedures match the design

- Verification that the code works and that the test results are recorded

- Supporting information is incorporated into the documentation

The time frame for performing independent $V \& V$ activities:

- After every major software object or sub section has been created or has undergone major modifications

- On an as-needed basis

- As required by contract

- As required by the NUREG/BR-0167. See Table 3-2 (of the NUREG) for the table of the reviews and audits.

\section{Perform a V\&V audit by a non-INL entity}

The plan includes an NRC peer review before the code is released for general use. The schedule for general release of SAPHIRE 8 supports the "Individual Peer Review" in Office Instruction PRM-010, Revision 0, "Peer Review of RES Projects." The schedule does not support an "External Peer Review," which could take much longer to complete. 


\begin{tabular}{|l|ll|}
\hline Idaho National Laboratory & Page: 65 of 74 \\
\hline SOFTWARE PROJECT PLAN & Identifier: & INL/EXT-09-15853 \\
for SAPHIRE Version 8 N6423 & Revision: & 4 \\
& Effective Date: & $3 / 3 / 2010$ \\
\hline
\end{tabular}

\section{Quality Assurance}




\section{$\underline{\text { Overview }}$}

\section{Change Design Process (Applicable to Version 7 and 8)}

Change design process when performing SAPHIRE maintenance or improvements:

1. Design the Change. The first step of implementing a new or revising an existing capability is to design the change. That is, INL shall carefully identify what exactly needs to be done and how it can best be implemented. The design stage includes, but is not limited to the following:

a. Interaction with the requestor(s) to ensure that the change as designed accomplishes its expected goal, and that it accomplishes it in an optimal way. This process will need to be ongoing with continual interaction with the requestor(s) to ensure that INL is providing the expected goal.

b. Identification of interfaces and interactions with other SAPHIRE features to ensure a correct and efficient implementation of the change.

2. Test the Change. Once the INL has implemented the change of update, it shall allow selected users, including the requestor(s) to test the software with its new features and ensure that it works as expected and is free of software defects.

3. Document the Change. The SAPHIRE Change Design Form will be used to document and track changes. The SAPHIRE Software Verification and Validation Plan (SVVP) shall be updated on a continual basis as part of the revision/adding of capabilities.

4. Update the Test Suite to Reflect the Change. The Test Suite used for testing and validating each new version of SAPHIRE should be examined on a continual basis and updated to ensure that it reflect the new or modified SAPHIRE capabilities. Changes to the Test Suite will be documented in the SAPHIRE SVVP Test plan.

Software QA procedures followed (Applicable to Version 7 and 8)

NUREG/BR-0167, “Software Quality Assurance Program and Guidelines,” February 1993.

INL report PDD-13610, “INL Software Quality Assurance Program” (effective April 2, 2007), LWP-13620, “INL Quality Assurance Program Implementation Plan” (effective April 2, 2007).

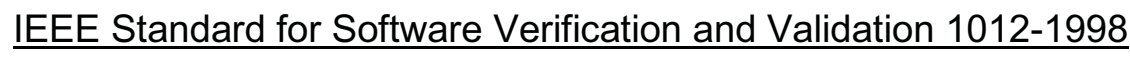

\section{SAPHIRE 7}




\begin{tabular}{|l|l|l|}
\hline Idaho National Laboratory & \multicolumn{2}{c|}{ Page: 67 of 74} \\
\hline SOFTWARE PROJECT PLAN & Identifier: & INL/EXT-09-15853 \\
for SAPHIRE Version 8 N6423 & Revision: & 4 \\
& Effective Date: & $3 / 3 / 2010$ \\
\hline
\end{tabular}

No requirements to follow this standard.

\section{SAPHIRE 8}

Required to satisfy four recommendations:

1. Reach a consensus on the target software integrity level [1, 2, 3, or 4].

2. Create a formal Software Verification and Validation Plan document that describes which V\&V activities shall and shall not be performed.

3. Utilize a functionally independent (from the developmental organization) V\&V person(s) for at least some V\&V functions.

4. Support a V\&V audit (i.e., peer review) by a non-INL entity.

See: Memorandum dated April 25, 2007, "Supplementary Response to Recommendations in OIG-06-A-24, "Evaluation of the NRC's Use of Probabilistic Risk Assessment in Regulating the Commercial Nuclear Power Industry," (ml070990040).

Audits (Applicable to Version 7 and 8)

Software QA audit required by Office Instruction PRM-12, "Software Quality Assurance for RESsponsored Codes," with a frequency of once per calendar year.

NUREG/CRs describing SAPHIRE 7 quality assurance:

NUREG/CR-6688, “Testing, Verifying, and Validating SAPHIRE Version 6.0 and 7.0," 2000,

Draft updated NUREG/CR (Volume 6), "Systems Analysis Programs for Hands-on Integrated Reliability Evaluations (SAPHIRE) Quality Assurance Manual.”

NUREG/CR describing SAPHIRE 8 quality assurance:

To be developed.

Other RES quality assurance requirements:

The quality of NRC research programs are assessed each year by the Advisory Committee on Reactor Safeguards. Within the context of their reviews of RES programs, the definition of quality research is based upon several major characteristics: 


\begin{tabular}{|l|ll|}
\hline Idaho National Laboratory & Page: 68 of 74 \\
\hline SOFTWARE PROJECT PLAN & Identifier: & INL/EXT-09-15853 \\
for SAPHIRE Version 8 N6423 & Revision: & 4 \\
& Effective Date: & $3 / 3 / 2010$ \\
\hline
\end{tabular}

Results meet the objectives ( $75 \%$ of overall score)

Justification of major assumptions (12\%)

Soundness of technical approach and results $(52 \%)$

Uncertainties and sensitivities addressed (11\%)

Documentation of research results and methods is adequate ( $25 \%$ of overall score)

Clarity of presentation (16\%)

Identification of major assumptions (9\%)

It is the responsibility of the contractor to ensure that these quality criteria are adequately addressed throughout the course of the research that is performed. The NRC project manager and technical monitor will review all research products with these criteria in mind. 


\begin{tabular}{|l|ll|}
\hline Idaho National Laboratory & Page: 69 of 74 \\
\hline SOFTWARE PROJECT PLAN & Identifier: & INL/EXT-09-15853 \\
for SAPHIRE Version 8 N6423 & Revision: & 4 \\
& Effective Date: & $3 / 3 / 2010$ \\
\hline
\end{tabular}

\section{Appendix B}

\section{List of SAPHIRE 7 and 8 Features}




\section{SOFTWARE PROJECT PLAN for SAPHIRE Version 8 N6423}

$\begin{array}{ll}\text { Identifier: } & \text { INL/EXT-09-15853 } \\ \text { Revision: } & 4 \\ \text { Effective Date: } & 3 / 3 / 2010\end{array}$

\begin{tabular}{|c|c|c|c|c|}
\hline \multirow[b]{2}{*}{ Item } & \multirow[b]{2}{*}{ Feature } & \multicolumn{3}{|c|}{ Version } \\
\hline & & 6.x & 7.x & 8.x \\
\hline $\mathbf{A}$ & Cut Set Sequence Generation & & & \\
\hline A.1 & Rule based Fault Tree Linking & $X$ & $X$ & $X$ \\
\hline A.2 & Linking of Small Tree Events & $\mathrm{X}$ & $\mathrm{X}$ & $\mathrm{X}$ \\
\hline A.3 & Linking of Large Tree Events & $\mathrm{X}$ & $\mathrm{X}$ & $\mathrm{X}$ \\
\hline B & Cut Set Generation for Fault Trees and Event Trees & $\mathrm{X}$ & $\mathrm{X}$ & $\mathrm{X}$ \\
\hline $\mathbf{C}$ & Cut Set Gathering for Sequence and End State Cut Sets & $\mathrm{X}$ & $\mathrm{X}$ & $\mathrm{X}$ \\
\hline $\mathbf{D}$ & Cut Set Partitioning via rules & $\mathrm{X}$ & $\mathrm{X}$ & $\mathrm{X}$ \\
\hline $\mathbf{E}$ & Cut Set Sorting & & & \\
\hline E.1 & By individual basic events & $X$ & $X$ & $X$ \\
\hline E.2 & By probability & & $\mathrm{X}$ & $\mathrm{X}$ \\
\hline E.3 & By rules & & $\mathrm{X}$ & $\mathrm{X}$ \\
\hline E.4 & Multiple cut set slicing & & & $\mathrm{X}$ \\
\hline $\mathbf{F}$ & Cut Set Post Processing (Recovery Rules) & & & \\
\hline F.1 & Event tree sequences & $X$ & $\mathrm{X}$ & $\mathrm{X}$ \\
\hline F.2 & Fault trees & $\mathrm{X}$ & $\mathrm{X}$ & $\mathrm{X}$ \\
\hline G & Change Sets (modifying select basic events for an analysis) & & & \\
\hline G.1 & Single event selection & $X$ & $X$ & $\mathrm{X}^{1}$ \\
\hline G.2 & Multiple event selection & $\mathrm{X}$ & $\mathrm{X}$ & $\mathrm{X}^{1}$ \\
\hline G.3 & Group event selection & $\mathrm{X}$ & $\mathrm{X}$ & $\mathrm{X}^{1}$ \\
\hline G.4 & Workspace area & & & $\mathrm{X}$ \\
\hline $\mathbf{H}$ & Flag Sets (setting basic events to True of False) & & & \\
\hline $\mathrm{H} .1$ & Static (predefined) flag sets & $\mathrm{X}$ & $\mathrm{X}$ & $\mathrm{X}$ \\
\hline $\mathrm{H} .2$ & Dynamic (rule based) flag sets & $\mathrm{X}$ & $\mathrm{X}$ & $\mathrm{X}$ \\
\hline I & Cut Set Quantification Methods & & & \\
\hline $\mathrm{I} .1$ & Minimal Cut Set Upper bound (min-cut) & $X$ & $\mathrm{X}$ & $\mathrm{X}$ \\
\hline 1.2 & Min-Max (exact, using inclusion/exclusion principle & $\mathrm{X}$ & $\mathrm{X}$ & $\mathrm{X}$ \\
\hline 1.3 & Rare Event & $\mathrm{X}$ & $\mathrm{X}$ & $\mathrm{X}$ \\
\hline 1.4 & Split Fraction (Sequences only) & $\mathrm{X}$ & $\mathrm{X}$ & $\mathrm{X}$ \\
\hline $\mathbf{J}$ & Cut Set Analysis & & & \\
\hline $\mathrm{J} .1$ & $\begin{array}{l}\text { Cut set generation - cut sets solved, gathered, with truncation by } \\
\text { size or probability, auto recovery }\end{array}$ & $\mathrm{X}$ & $\mathrm{X}$ & $\mathrm{X}$ \\
\hline J.2 & Cut set path tracing through logic model & $\mathrm{X}$ & $\mathrm{X}$ & $\mathrm{X}$ \\
\hline J.3 & Cut set comparison between two cases & $\mathrm{X}$ & $\mathrm{X}$ & $\mathrm{X}$ \\
\hline J.4 & Cut set comparison including probability changes & & & $\mathrm{X}$ \\
\hline J.5 & Fault tree & $\mathrm{X}$ & $\mathrm{X}$ & $\mathrm{X}$ \\
\hline J.6 & Event tree sequences & $\mathrm{X}$ & $\mathrm{X}$ & $\mathrm{X}$ \\
\hline J.7 & End states & $\mathrm{X}$ & $\mathrm{X}$ & $\mathrm{X}$ \\
\hline K & Basic Events & & & \\
\hline K.1 & Basic event correlation designation & $\mathrm{X}$ & $\mathrm{X}$ & $\mathrm{X}$ \\
\hline K.2 & Basic event templates (reuse of a single event) & $\mathrm{X}$ & $\mathrm{X}$ & $\mathrm{X}$ \\
\hline K.3 & Compound events (plug in modules) & & & $\mathrm{X}$ \\
\hline K.3.1 & Common-cause alpha-factor module & $\mathrm{X}$ & $\mathrm{X}$ & $\mathrm{X}$ \\
\hline K.3.2 & Common-cause alpha-factor (staggered) module & $\mathrm{X}$ & $\mathrm{X}$ & $\mathrm{X}$ \\
\hline
\end{tabular}




\section{SOFTWARE PROJECT PLAN for SAPHIRE Version 8 N6423}

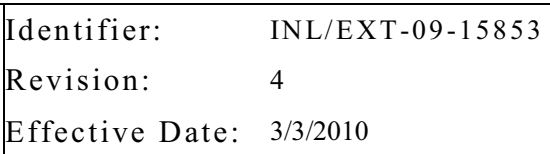

\begin{tabular}{|c|c|c|c|c|}
\hline \multirow[b]{2}{*}{ Item } & \multirow[b]{2}{*}{ Feature } & \multicolumn{3}{|c|}{ Version } \\
\hline & & $6 . x$ & $7 . x$ & 8.x \\
\hline K.3.3 & Common-cause beta-factor module & $\mathrm{X}$ & $\mathrm{X}$ & $\mathrm{X}$ \\
\hline K.3.4 & Common-cause multiple Greek letter module & $\mathrm{X}$ & $\mathrm{X}$ & $\mathrm{X}$ \\
\hline K.3.5 & Loss-of-offsite power frequency and recovery module & & $\mathrm{X}$ & $\mathrm{X}$ \\
\hline K.3.6 & Time Series module & $\mathrm{X}$ & $\mathrm{X}$ & $\mathrm{X}$ \\
\hline K.3.7 & General purpose utility module & $\mathrm{X}$ & $\mathrm{X}$ & $\mathrm{X}$ \\
\hline K.3.8 & Load-capacity module & & $\mathrm{X}$ & $\mathrm{X}$ \\
\hline K.3.9 & Flow acceleration corrosion pipe module & $\mathrm{X}$ & $\mathrm{X}$ & $\mathrm{X}$ \\
\hline $\begin{array}{l}\text { K.3.1 } \\
0\end{array}$ & User defined module & & & $\mathrm{X}$ \\
\hline K.4 & Failure probability on demand & $\mathrm{X}$ & $\mathrm{X}$ & $\mathrm{X}$ \\
\hline K.5 & Failure probability to run & $\mathrm{X}$ & $\mathrm{X}$ & $\mathrm{X}$ \\
\hline K.6 & Value input (for any value) & & $\mathrm{X}$ & $\mathrm{X}$ \\
\hline K.7 & Failure probability to run $\mathrm{w} /$ repair & $\mathrm{X}$ & $\mathrm{X}$ & $\mathrm{X}$ \\
\hline K.8 & Failure probability to run & $\mathrm{X}$ & $\mathrm{X}$ & $\mathrm{X}$ \\
\hline K.9 & House event True (Probability = 1.0) i.e. failed & $\mathrm{X}$ & $\mathrm{X}$ & $\mathrm{X}$ \\
\hline K.10 & House event False (Probability $=0.0$ ) i.e. success & $\mathrm{X}$ & $\mathrm{X}$ & $\mathrm{X}$ \\
\hline K.11 & House event Ignore & $\mathrm{X}$ & $\mathrm{X}$ & $\mathrm{X}$ \\
\hline K.12 & Human Factor Event & & $\mathrm{X}$ & $\mathrm{X}$ \\
\hline K.13 & Fault tree Min Cut Upper Bound Value & $\mathrm{X}$ & $\mathrm{X}$ & $\mathrm{X}$ \\
\hline K.14 & End State Min Cut Upper Bound Value & $\mathrm{X}$ & $\mathrm{X}$ & $\mathrm{X}$ \\
\hline K.15 & Seismic screening using user-specified ground acceleration value & $\mathrm{X}$ & $\mathrm{X}$ & $\mathrm{X}$ \\
\hline K.16 & Seismic screening using hazard curve & $\mathrm{X}$ & $\mathrm{X}$ & $\mathrm{X}$ \\
\hline $\mathbf{L}$ & Importance Measures & & & \\
\hline L.1 & Fussell-Vesely importance measure & $\mathrm{X}$ & $\mathrm{X}$ & $\mathrm{X}$ \\
\hline L.2 & Birnbaum importance measure & $\mathrm{X}$ & $\mathrm{X}$ & $\mathrm{X}$ \\
\hline L.3 & Risk increase ratio importance measure & $\mathrm{X}$ & $\mathrm{X}$ & $\mathrm{X}$ \\
\hline L.4 & Risk reduction ratio importance measure & $\mathrm{X}$ & $\mathrm{X}$ & $\mathrm{X}$ \\
\hline L.5 & Risk increase interval importance measure & $\mathrm{X}$ & $\mathrm{X}$ & $\mathrm{X}$ \\
\hline L.6 & Risk reduction interval importance measure & $\mathrm{X}$ & $\mathrm{X}$ & $\mathrm{X}$ \\
\hline L.7 & Group importance measure & $\mathrm{X}$ & $\mathrm{X}$ & $\mathrm{X}$ \\
\hline L.8 & Uncertainty determination on importance measures & & $\mathrm{X}$ & $\mathrm{X}$ \\
\hline $\mathbf{M}$ & Model Creation & & & \\
\hline M.1 & Seismic, fire and flooding transformation capability & $\mathrm{X}$ & $\mathrm{X}$ & $\mathrm{X}$ \\
\hline M.2 & Fault tree logic editor & $\mathrm{X}$ & $\mathrm{X}$ & $\mathrm{X}$ \\
\hline M.3 & Fault tree graphical editor & $\mathrm{X}$ & $\mathrm{X}$ & $\mathrm{X}$ \\
\hline M.4 & Event tree graphical editor & $\mathrm{X}$ & $\mathrm{X}$ & $\mathrm{X}$ \\
\hline M.5 & Fault tree and event tree "drag and drop" editor & & & $\mathrm{X}$ \\
\hline M.6 & Streamlined data entry screens & & & $\mathrm{X}$ \\
\hline M.7 & Fault tree viewer showing model-type information (e.g., fire, flood) & & & $\mathrm{X}$ \\
\hline M.8 & Multiple editing windows open at the same time & & & $\mathrm{X}$ \\
\hline $\mathbf{N}$ & Model Creation Load / Extract Data Models (MAR-D) & & & \\
\hline N.1 & All data and file types concurrently & & $\mathrm{X}$ & $\mathrm{X}$ \\
\hline N.2 & $\begin{array}{l}\text { Project files (primary descriptions, attributes, recovery rules, fault } \\
\text { tree recovery rules, partition rules, primary text) }\end{array}$ & $\mathrm{X}$ & $\mathrm{X}$ & $\mathrm{X}$ \\
\hline N.3 & Project files (alternate description, alternate text) & & $\mathrm{X}$ & $\mathrm{X}$ \\
\hline
\end{tabular}




\section{SOFTWARE PROJECT PLAN for SAPHIRE Version 8 N6423}

\begin{tabular}{|c|c|c|c|c|}
\hline \multirow[b]{2}{*}{ Item } & \multirow[b]{2}{*}{ Feature } & \multicolumn{3}{|c|}{ Version } \\
\hline & & 6.x & $7 . x$ & 8.x \\
\hline N.4 & Attributes (primary attributes) & $\mathrm{X}$ & $\mathrm{X}$ & $\mathrm{X}$ \\
\hline N.5 & Attributes (all attributes, alternate attributes) & & $\mathrm{X}$ & $\mathrm{X}$ \\
\hline N.6 & $\begin{array}{l}\text { Basic event files (description, rate information, attributes, } \\
\text { transformations) }\end{array}$ & $\mathrm{X}$ & $\mathrm{X}$ & $\mathrm{X}$ \\
\hline N.7 & $\begin{array}{l}\text { Basic event files (alternate description, text, alternate text, } \\
\text { compound events) }\end{array}$ & & $\mathrm{X}$ & $\mathrm{X}$ \\
\hline N.8 & $\begin{array}{l}\text { Fault tree files (description, logic, graphics, cut sets, attributes, } \\
\text { recovery rules, primary text, PID diagrams) }\end{array}$ & $\mathrm{X}$ & $\mathrm{X}$ & $\mathrm{X}$ \\
\hline N.9 & Fault tree files (alternate description, alternate text) & & $X$ & $X$ \\
\hline N.10 & $\begin{array}{l}\text { Event tree files (description, graphics, logic, attributes, linking } \\
\text { rules, recovery rules, partition, primary text) }\end{array}$ & $\mathrm{X}$ & $\mathrm{X}$ & $\mathrm{X}$ \\
\hline N.11 & Event tree files (alternate description, alternate Text) & & $\mathrm{X}$ & $\mathrm{X}$ \\
\hline N.12 & $\begin{array}{l}\text { End state files (description, cut sets, textual information, primary } \\
\text { text) }\end{array}$ & $\mathrm{X}$ & $\mathrm{X}$ & $\mathrm{X}$ \\
\hline N.13 & End state files (alternate description, alternate text) & & $\mathrm{X}$ & $\mathrm{X}$ \\
\hline N.14 & $\begin{array}{l}\text { Sequence files (description, logic, cut sets, attributes, recovery } \\
\text { rules, primary text) }\end{array}$ & $X$ & $\mathrm{X}$ & $\mathrm{X}$ \\
\hline N.15 & Sequence files (partitions, alternate description, alternate text) & & $\mathrm{X}$ & $\mathrm{X}$ \\
\hline N.16 & Gate information files (description, attributes) & $X$ & $\mathrm{X}$ & $\mathrm{X}$ \\
\hline N.17 & Gate information files (alternate description) & & $\mathrm{X}$ & $\mathrm{X}$ \\
\hline N.18 & Change Set files (description, information) & $\mathrm{X}$ & $\mathrm{X}$ & $\mathrm{X}$ \\
\hline N.19 & Change Set files (attributes, alternate description) & & $\mathrm{X}$ & $\mathrm{X}$ \\
\hline N.20 & Histogram files (description, information) & $\mathrm{X}$ & $\mathrm{X}$ & $\mathrm{X}$ \\
\hline N.21 & Histogram files (attributes, alternate description) & & $\mathrm{X}$ & $\mathrm{X}$ \\
\hline N.22 & Slice files (description, basic events, information) & $\mathrm{X}$ & $\mathrm{X}$ & $\mathrm{X}$ \\
\hline N.23 & Slice files (attributes, alternate description) & & $\mathrm{X}$ & $\mathrm{X}$ \\
\hline N.24 & Multi-phase feature & & & $\mathrm{X}$ \\
\hline N.25 & Event sequence diagrams & & & $\mathrm{X}$ \\
\hline N.26 & Reliability block diagrams & & & $\mathrm{X}$ \\
\hline $\mathbf{O}$ & $\begin{array}{l}\text { Model Creation Logic Gate Types (Max inputs } 256 \text { unless } \\
\text { otherwise specified) }\end{array}$ & & & \\
\hline 0.1 & AND & $\mathrm{X}$ & $\mathrm{X}$ & $\mathrm{X}$ \\
\hline 0.2 & OR & $X$ & $X$ & $X$ \\
\hline 0.3 & $\mathrm{~N}$ of $\mathrm{M}(\mathrm{Max} \mathrm{N}=98, \mathrm{Max} \mathrm{M}=99)$ & $\mathrm{X}$ & $\mathrm{X}$ & $\mathrm{X}$ \\
\hline 0.4 & NAND (Not AND) & $\mathrm{X}$ & $\mathrm{X}$ & $\mathrm{X}$ \\
\hline 0.5 & NOR (Not OR) & $\mathrm{X}$ & $\mathrm{X}$ & $\mathrm{X}$ \\
\hline O.6 & Transfer Gate & $\mathrm{X}$ & $\mathrm{X}$ & $\mathrm{X}$ \\
\hline 0.7 & Left/right transfer marker & $\mathrm{X}$ & $\mathrm{X}$ & $\mathrm{X}$ \\
\hline 0.8 & Undeveloped transfer & $\mathrm{X}$ & $\mathrm{X}$ & $\mathrm{X}$ \\
\hline 0.9 & Inhibit gate & $\mathrm{X}$ & $\mathrm{X}$ & $\mathrm{X}$ \\
\hline 0.10 & Basic event & $\mathrm{X}$ & $\mathrm{X}$ & $\mathrm{X}$ \\
\hline 0.11 & Boxed basic event & $\mathrm{X}$ & $\mathrm{X}$ & $\mathrm{X}$ \\
\hline 0.12 & Undeveloped basic event & $\mathrm{X}$ & $\mathrm{X}$ & $\mathrm{x}$ \\
\hline 0.13 & Table of basic events & $\mathrm{X}$ & $\mathrm{X}$ & $\mathrm{X}$ \\
\hline 0.14 & House event & $\mathrm{X}$ & $\mathrm{X}$ & $\mathrm{X}$ \\
\hline
\end{tabular}




\section{SOFTWARE PROJECT PLAN for SAPHIRE Version 8 N6423}

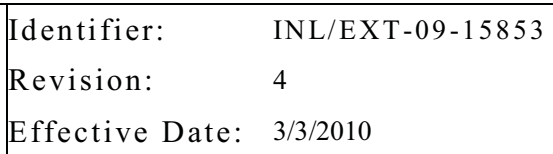

\begin{tabular}{|c|c|c|c|c|}
\hline \multirow[b]{2}{*}{ Item } & \multirow[b]{2}{*}{ Feature } & \multicolumn{3}{|c|}{ Version } \\
\hline & & 6.x & $7 . x$ & 8.x \\
\hline 0.15 & Vertical/horizontal text box & $\mathrm{X}$ & $\mathrm{X}$ & $\mathrm{X}$ \\
\hline $\mathbf{P}$ & $\begin{array}{l}\text { Uncertainty Calculations Monte Carlo and Latin Hyper Cube } \\
\text { Sampling }\end{array}$ & & & \\
\hline P.1 & Normal distribution & $\mathrm{X}$ & $\mathrm{X}$ & $\mathrm{X}$ \\
\hline P.2 & Lognormal distribution & $\mathrm{X}$ & $\mathrm{X}$ & $\mathrm{X}$ \\
\hline P.3 & Beta distribution & $\mathrm{X}$ & $\mathrm{X}$ & $\mathrm{X}$ \\
\hline P.4 & Chi Squared distribution & $\mathrm{X}$ & $\mathrm{X}$ & $\mathrm{X}$ \\
\hline P.5 & Exponential distribution & $\mathrm{X}$ & $\mathrm{X}$ & $\mathrm{X}$ \\
\hline P.6 & Uniform distribution & $\mathrm{X}$ & $\mathrm{X}$ & $\mathrm{X}$ \\
\hline P.7 & Constrained non-informative distribution & $\mathrm{X}$ & $\mathrm{x}$ & $\mathrm{X}$ \\
\hline P.8 & Gamma distribution & $\mathrm{X}$ & $\mathrm{x}$ & $\mathrm{X}$ \\
\hline P.9 & Maximum entropy distribution & $\mathrm{X}$ & $\mathrm{X}$ & $\mathrm{X}$ \\
\hline P.10 & Dirichlet distribution & $\mathrm{X}$ & $\mathrm{X}$ & $\mathrm{X}$ \\
\hline P.11 & Seismic log normal analysis & $\mathrm{X}$ & $\mathrm{X}$ & $\mathrm{X}$ \\
\hline P.12 & Histogram distribution & $\mathrm{X}$ & $\mathrm{X}$ & $\mathrm{X}$ \\
\hline P.13 & Triangular distribution & & $\mathrm{X}$ & $\mathrm{X}$ \\
\hline $\mathbf{Q}$ & Uncertainty Calculations Parameter Settings & & & \\
\hline Q.1 & User defined seed, sample size, number of iterations & $\mathrm{X}$ & $\mathrm{X}$ & $\mathrm{X}$ \\
\hline Q.2 & Output intermediate values to file & $x$ & $\mathrm{X}$ & $\mathrm{x}$ \\
\hline Q.3 & Output intermediate values in CSV format & & $\mathrm{X}$ & $\mathrm{X}$ \\
\hline $\mathbf{R}$ & General Support Features & & & \\
\hline R.1 & Sensitivity wizard & & $\mathrm{X}$ & $\mathrm{X}$ \\
\hline R.2 & Importance measures wizard & & $\mathrm{X}$ & $\mathrm{X}$ \\
\hline R.3 & Embedded macro capability & & $\mathrm{X}$ & $\mathrm{X}$ \\
\hline R.4 & Editing user information & & $\mathrm{X}$ & $\mathrm{X}$ \\
\hline R.5 & Page numbering control on graphic format & $\mathrm{X}$ & $\mathrm{X}$ & $\mathrm{x}$ \\
\hline R.6 & Conversion from alpha to graphic format & $\mathrm{X}$ & $\mathrm{X}$ & $\mathrm{X}$ \\
\hline R.7 & On-line context sensitive help & & $\mathrm{X}$ & $\mathrm{X}$ \\
\hline R.8 & Parallel processing (Linux only) & & $\mathrm{X}$ & $\mathrm{X}$ \\
\hline R.9 & Database recovery & $\mathrm{X}$ & $\mathrm{X}$ & $x$ \\
\hline R.10 & Designate output folder location & & $\mathrm{X}$ & $\mathrm{X}$ \\
\hline R.11 & Graphical export to windows metafiles & $\mathrm{X}$ & $\mathrm{X}$ & $\mathrm{X}$ \\
\hline $\mathbf{S}$ & General Support Features Report Generation & & & \\
\hline S.1 & $\begin{array}{l}\text { Project reports (summary, text, letter report, statistics, custom } \\
\text { report) }\end{array}$ & $\mathrm{X}$ & $\mathrm{X}$ & $\mathrm{X}$ \\
\hline S.2 & $\begin{array}{l}\text { Project reports (fault tree recovery rules, sequence recovery rules, } \\
\text { partition rules, uncertainty reports) }\end{array}$ & & $\mathrm{X}$ & $\mathrm{X}$ \\
\hline S.3 & $\begin{array}{l}\text { Attributes (system, location, failure mode, basic event, train type, } \\
\text { custom reports) }\end{array}$ & $\mathrm{X}$ & $\mathrm{X}$ & $\mathrm{X}$ \\
\hline S.4 & $\begin{array}{l}\text { Basic event (overview, probability, uncertainty, seismic, } \\
\text { transformation, cross reference, custom reports) }\end{array}$ & $\mathrm{X}$ & $\mathrm{X}$ & $\mathrm{X}$ \\
\hline S.5 & $\begin{array}{l}\text { Basic event (compound event, developed events, template events, } \\
\text { text information) }\end{array}$ & & $\mathrm{X}$ & $\mathrm{X}$ \\
\hline S.6 & $\begin{array}{l}\text { Fault tree (summary, logic, graphics, cut sets, importance } \\
\text { measures, cross reference, custom reports) }\end{array}$ & $X$ & $X$ & $X$ \\
\hline
\end{tabular}




$\begin{array}{ll}\text { Identifier: } & \text { INL/EXT-09-15853 } \\ \text { Revision: } & 4 \\ \text { Effective Date: } & 3 / 3 / 2010\end{array}$

\begin{tabular}{|c|c|c|c|c|}
\hline \multirow[b]{2}{*}{ Item } & \multirow[b]{2}{*}{ Feature } & \multicolumn{3}{|c|}{ Version } \\
\hline & & 6.x & $7 . x$ & 8.x \\
\hline S.7 & Fault tree (recovery rules, text information) & & $\mathrm{X}$ & $\mathrm{X}$ \\
\hline S.8 & $\begin{array}{l}\text { Event tree (logic, graphics, initiating events, cross reference, } \\
\text { custom reports) }\end{array}$ & $\mathrm{X}$ & $\mathrm{X}$ & $\mathrm{X}$ \\
\hline S. 9 & $\begin{array}{l}\text { Event tree (linkage rules, recovery rules, partition rules, text } \\
\text { information) }\end{array}$ & & $\mathrm{X}$ & $\mathrm{X}$ \\
\hline S.10 & $\begin{array}{l}\text { End state (summary, cut sets, importance measures, cross } \\
\text { reference, custom reports) }\end{array}$ & $\mathrm{X}$ & $\mathrm{X}$ & $\mathrm{X}$ \\
\hline S.11 & End state (text information) & & $\mathrm{X}$ & $\mathrm{X}$ \\
\hline S.12 & $\begin{array}{l}\text { Sequence (summary, logic, cut sets, importance measures, } \\
\text { custom reports) }\end{array}$ & $\mathrm{X}$ & $\mathrm{X}$ & $\mathrm{X}$ \\
\hline S.13 & Sequence (recovery rules, partition rules, text information) & & $\mathrm{X}$ & $\mathrm{X}$ \\
\hline S.14 & $\begin{array}{l}\text { Change Set (summary, class, single, text information, custom } \\
\text { reports) }\end{array}$ & & $\mathrm{X}$ & $\mathrm{X}$ \\
\hline S.15 & $\begin{array}{l}\text { Flag Set (summary, flag set events, cross reference, text } \\
\text { information, custom reports) }\end{array}$ & & $\mathrm{X}$ & $\mathrm{X}$ \\
\hline S.16 & Gate (cross reference, custom reports) & $\mathrm{X}$ & $\mathrm{X}$ & $\mathrm{X}$ \\
\hline S.17 & Histogram (summary, detailed, custom report) & $\mathrm{X}$ & $\mathrm{X}$ & $\mathrm{X}$ \\
\hline S.18 & Histogram (cross reference) & & $\mathrm{X}$ & $\mathrm{X}$ \\
\hline S.19 & $\begin{array}{l}\text { Slice (summary, rule summary, slice events, slice rule, custom } \\
\text { reports) }\end{array}$ & & $\mathrm{X}$ & $\mathrm{X}$ \\
\hline S.20 & User Info/preferences & $\mathrm{X}$ & $\mathrm{X}$ & $\mathrm{X}$ \\
\hline S.21 & SPAR model report outputs & & $\mathrm{X}$ & $\mathrm{X}$ \\
\hline S.22 & Advanced graphical plotting output (e.g., pie charts, histograms) & & & $\mathrm{X}$ \\
\hline $\mathbf{T}$ & Report Format Types: & & & \\
\hline $\mathrm{T} .1$ & ASCII & $\mathrm{X}$ & $\mathrm{X}$ & $\mathrm{X}$ \\
\hline T.2 & RTF & & $\mathrm{X}$ & $\mathrm{X}$ \\
\hline T.3 & HTML & & $\mathrm{X}$ & $\mathrm{X}$ \\
\hline T.4 & PDF & & & $\mathrm{X}$ \\
\hline $\mathbf{U}$ & General Analysis Types & & & \\
\hline U.1 & Initiating Event Analysis (formerly GEM) & $\mathrm{X}$ & $\mathrm{X}$ & $\mathrm{X}$ \\
\hline U.2 & Condition Assessment Analysis (formerly GEM) & $\mathrm{X}$ & $\mathrm{X}$ & $\mathrm{X}$ \\
\hline U.3 & Accident Sequence Precursor & $\mathrm{X}$ & $\mathrm{X}$ & $\mathrm{X}$ \\
\hline U.4 & User Define Analysis types & $\mathrm{X}$ & $\mathrm{X}$ & \\
\hline U.4 & User Define Model types & & & $\mathrm{X}$ \\
\hline U.5 & Significance Determination Process (SDP) & & & $\mathrm{X}$ \\
\hline U.6 & Generic Issue Resolution & & & $\mathrm{X}$ \\
\hline V & Application Program Interface & & & \\
\hline V.1 & Microsoft Visual Basic Interface & $\mathrm{X}$ & $\mathrm{X}$ & $\mathrm{X}$ \\
\hline V.2 & Microsoft Visual ClC++ Interface & $\mathrm{X}$ & $\mathrm{X}$ & $\mathrm{X}$ \\
\hline V.3 & Borland Delphi Object Oriented Pascal & & $\mathrm{X}$ & $\mathrm{X}$ \\
\hline
\end{tabular}

